Elver Luiz Mayer

\title{
PROCESSOS DE FORMAÇÃO DE UM DEPÓSITO FOSSILÍFERO EM ABISMO NA GRUTA CUVIERI (MG): TAXONOMIA, TAFONOMIA E DISTRIBUIÇÃO ESPACIAL DE FÓSSEIS DE MAMÍFEROS DO PLEISTOCENO
}

\footnotetext{
"FORMATION PROCESSES OF A FOSSILIFEROUS PITFALL DEPOSIT IN GRUTA CUVIERI (MG): TAXONOMY, TAPHONOMY AND SPACIAL DISTRIBUTION OF MAMMAL FOSSILS FROM THE PLEISTOCENE"
} 


\title{
Elver Luiz Mayer
}

\section{Versão corrigida}

(O original encontra-se disponível na biblioteca do Instituto de Biociências)

\section{PROCESSOS DE FORMAÇÃO DE UM DEPÓSITO FOSSILÍFERO EM ABISMO NA GRUTA CUVIERI (MG): TAXONOMIA, TAFONOMIA E DISTRIBUIÇÃO ESPACIAL DE FÓSSEIS DE MAMÍFEROS DO PLEISTOCENO}

\begin{abstract}
"FORMATION PROCESSES OF A FOSSILIFEROUS PITFALL DEPOSIT IN GRUTA CUVIERI (MG): TAXONOMY, TAPHONOMY AND SPACIAL DISTRIBUTION OF MAMMAL FOSSILS FROM THE PLEISTOCENE"
\end{abstract}

Dissertação apresentada ao Instituto de Biociências da Universidade de São Paulo para a obtenção de Título de Mestre em Ciências, na Área de Ecologia: ecossistemas terrestres e aquáticos.

Orientador: Prof. Dr. Walter Alves Neves

São Paulo 
Mayer, Elver Luiz

Processos de formação de um depósito fossilífero em abismo na Gruta Cuvieri (MG): taxonomia, tafonomia e distribuição espacial de fósseis de mamíferos do Pleistoceno / Elver Luiz Mayer. -- São Paulo : E.L.M., 2011

145 p. : il. + anexos

Dissertação (Mestrado) - Instituto de Biociências da Universidade de São Paulo. Departamento de Ecologia, 2011.

1. Lagoa Santa 2.Paleomastozoologia 3.Caverna 4. Carste 5.Contexto estratigráfico I. Universidade de São Paulo. Instituto de Biociências. Departamento de Ecologia

Comissão Julgadora:

$\operatorname{Prof}(\mathrm{a}) . \operatorname{Dr}(\mathrm{a})$

$\operatorname{Prof}(\mathrm{a}) . \operatorname{Dr}(\mathrm{a})$.

Prof. Dr. Walter Alves Neves

Orientador 
A Everton, Rodrigo e Stefani 


\section{Agradecimentos}

Agradeço primeiramente ao meu orientador, Walter Alves Neves, pelas oportunidades proporcionadas, sobretudo, de participar das escavações na sensacional região de Lagoa Santa. Agradeço-o também pelas leituras críticas que fez deste trabalho, pela motivação durante seu desenvolvimento e pela estrutura física de que desfrutei no Laboratório de Estudos Evolutivos Humanos (LEEH).

À FAPESP, pela concessão da bolsa de mestrado associada a este trabalho (processo: 2009/03753-4).

Agradeço também a Alex Hubbe pelo companheirismo, pelas valiosas conversas sobre a Gruta Cuvieri e o universo da pesquisa paleontológica em geral. Agradeço-o ainda, especialmente, pelas incontáveis orientações dadas ao longo do desenvolvimento deste trabalho.

Agradeço a Paulo Haddad-Martim pela prontidão com que dirimiu minhas dúvidas sobre a sedimentação na Gruta Cuvieri e cumprimento-o pelo importante trabalho que desenvolveu caracterizando os depósitos sedimentares da Gruta Cuvieri.

Aos demais amigos do LEEH: Max, Rodrigo, Strauss, Danilo, Pedro Tótora, Mark, Pedro Damin, Fábio, Marcão, Jânio, Xureta, Fofa, Capenga, Marcos, Cassiana, Helbert, Rafael, Alberto, Márcia, Michele, Nina, Mariana, Lívia, Carol, assim como tantos outros que contribuíram para as escavações e a cura do material da Gruta Cuvieri, mesmo que de maneira meteórica.

Aos professores Astolfo Araújo, Renato Kipnis e Rui Murrieta pela amizade e presteza no esclarecimento das mais diversas questões do mundo científico.

Ao professor Luis Beethoven Piló, por atender-me com importantes materiais e informações.

Ao Programa de Pós-Graduação em Ecologia, especificamente aos professores Paulo Inácio e Glauco e às secretárias Dalva e Socorro, pelo empenho em aprimorar o programa e pelos esclarecimentos sobre o regimento, os prazos, a verba PROAP...

Às secretárias do Departamento de Genética e Biologia Evolutiva, Helenice e Deisy, pela simpatia e auxílio na resolução de contratempos burocráticos.

A Autodesk pela iniciativa de disponibilizar seus programas gratuitamente para fins acadêmicos. 
A Paulo Auricchio por receber-me, cru como só um primeiroanista pode ser, como estagiário no Instituto Pau-Brasil e por encaminhar-me ao Instituto Butantan, onde pela primeira vez entrei em contato com o ambiente de pesquisa.

À Juliana Gualda de Barros e Mário de Vivo do Museu de Zoologia da USP e à Stella Maris Franco e João Alves de Oliveira do Museu Nacional do Rio de Janeiro pela solicitude durante as consultas que realizei as coleções sob as respectivas guardas.

Aos meus professores da graduação que, cada um ao seu modo, me cativou e me mostrou algumas das maravilhas do mundo biológico.

Aos amigos que conheci pelo convívio na USP: Kengi e Rafael, pelas dicas de informática e pelos momentos de descontração, incluindo aí o Fat e o Jorgera.

Aos amigos de casa: Normando, Jonatan e Leonel, pelo companheirismo. Ao novo morador, Luis Pezo, pelas dicas que me deu na redação da dissertação.

Aos amigos que conheci na Fundação Santo André, ah... são tantas emoções...

Aos meus padrinhos mágicos: Rosi Schereiber Ferreira e Márcio Ferreira, pelo apoio que sempre me deram e pelo auxílio com os programas 3D.

Ao meu irmão, Paulo Augusto Mayer, pelas broncas e barras pesadas que enfrentou em prol do meu bem estar e, como se não bastasse, pelo auxílio com os programas 3D.

À Paulina Mayer, minha mãe, agradeço por tantos motivos que eu jamais poderei listá-los completamente.

À Jéssica Souza, pela graciosa companhia nesta parceria amorosa que temos construído!!! ; ) 


\section{Sumário}

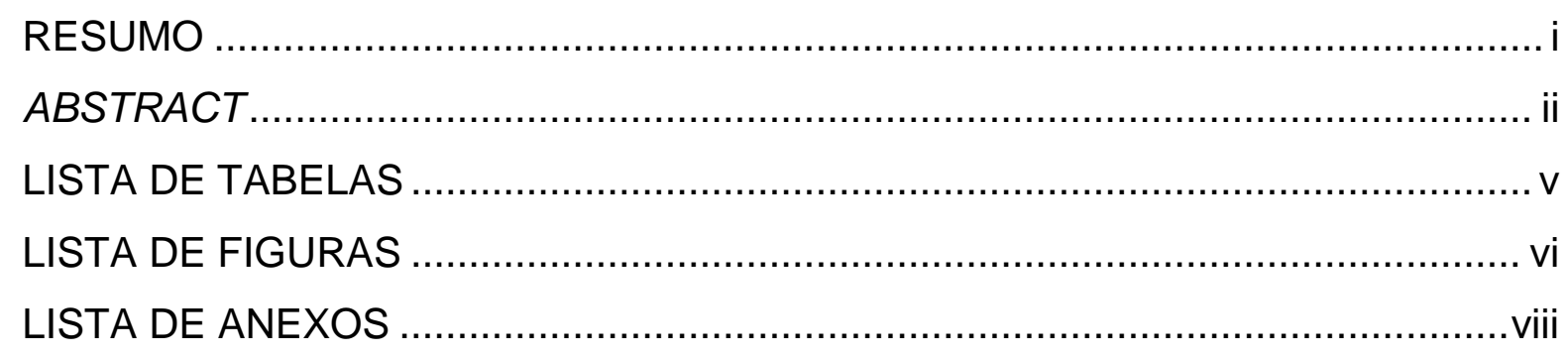

\section{INTRODUÇÃO}

1.1. A paleomastozoologia na região de Lagoa Santa ...................1

1.2. A Gruta Cuvieri ................................................................

1.3. Tafonomia e a distribuição espacial de fósseis $\ldots \ldots \ldots \ldots \ldots \ldots \ldots . \ldots 14$

2. CURA E IDENTIFICAÇÃO DO MATERIAL .................................. 18

2.1. Grupos taxonômicos identificados ................................. 18

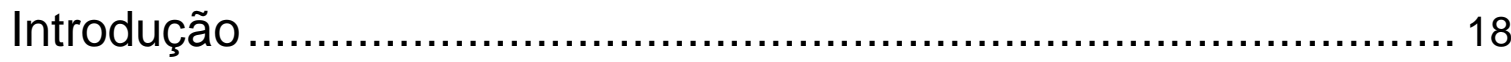

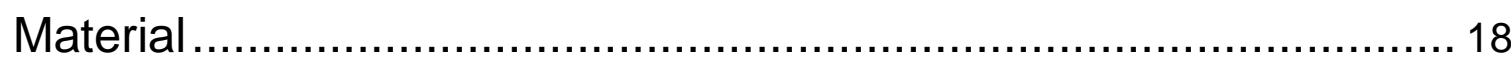

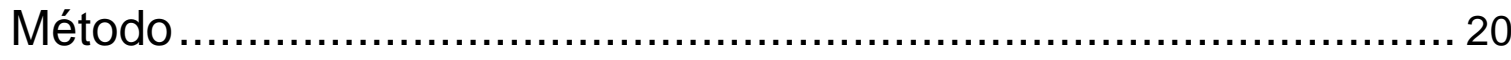

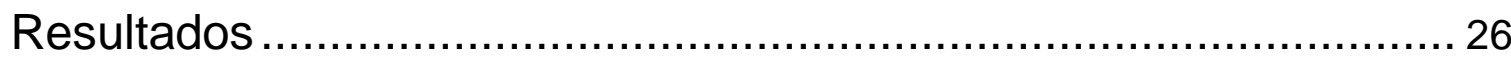

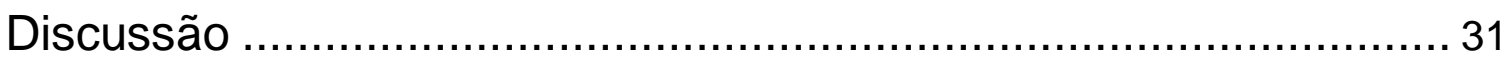

2.2. O registro fóssil do gênero Cuniculus............................... 41

Introdução ........................................................................ 41

Material e método ................................................................ 43

Resultados ............................................................................ 43

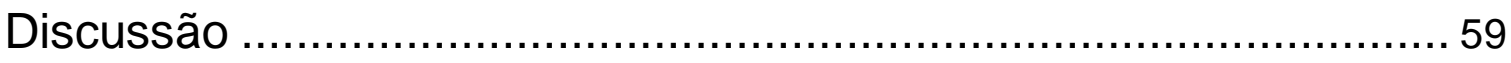

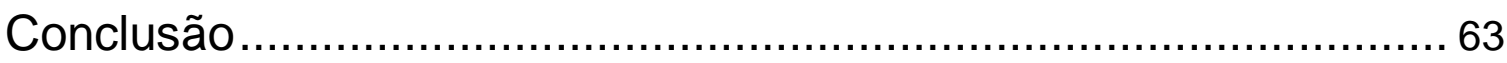

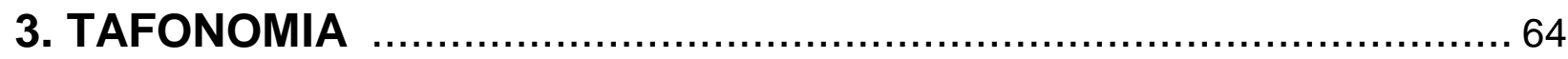




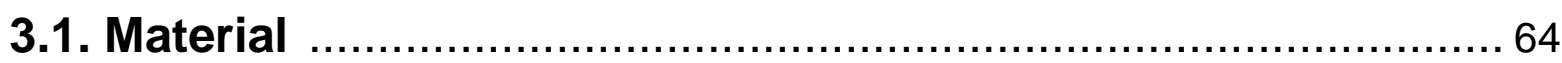

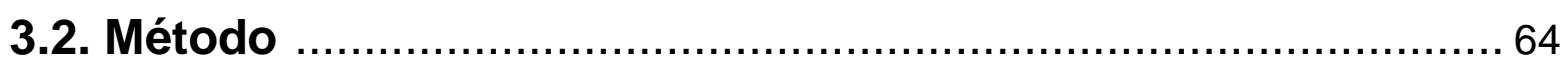

Distribuição segundo o grupo taxonômico ...................................... 65

Estado de fragmentação ............................................................. 65

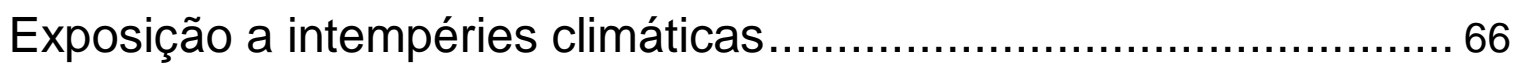

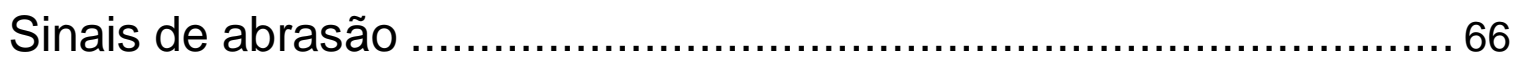

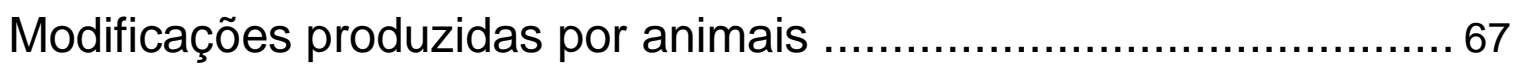

Distribuição de peças complementares (remontagem) ....................6 68

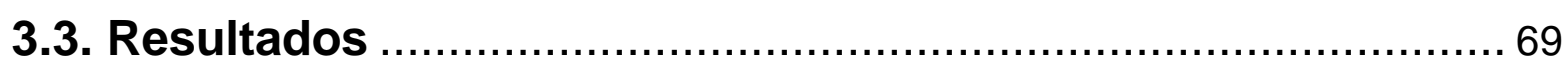

Distribuição segundo o grupo taxonômico ......................................69 69

Estado de fragmentação ........................................................... 78

Exposição a intempéries climáticas........................................... 82

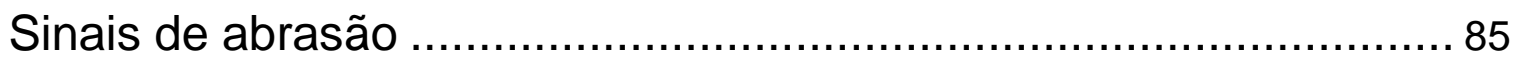

Modificações produzidas por animais: roedores............................. 88

Modificações produzidas por animais: carnívoros ........................... 91

Distribuição de peças complementares (remontagem)................... 94

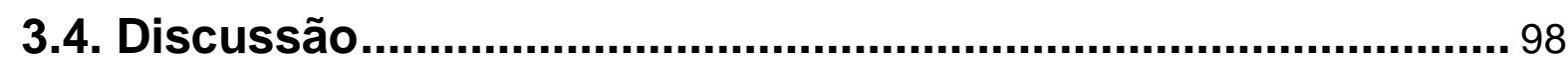

Distribuição segundo o grupo taxonômico ................................... 98

Estado de fragmentação ....................................................... 101

Exposição a intempéries climáticas............................................ 106

Sinais de abrasão .............................................................. 108

Modificações produzidas por animais: roedores.......................... 112

Modificações produzidas por animais: carnívoros ......................... 114

Distribuição de peças complementares (remontagem).................. 116

4. CONSIDERAÇÕES FINAIS E CONCLUSÃO 
6. ANEXOS 


\section{RESUMO}

A ausência de informações sobre a fauna de mamíferos do Pleistoceno brasileiro que vão além de estudos taxonômicos/descritivos e a carência de escavações com um controle estratigráfico mínimo motivaram as intervenções nos depósitos da Gruta Cuvieri (Lagoa Santa, Minas Gerais, Brasil) aplicando-se um método de escavação refinado. Este método registrou em detalhe a distribuição espacial dos fósseis, bem como o contexto sedimentar em que estavam depositados, representando uma investida pioneira para a paleomastozoologia nacional. $\mathrm{O}$ objetivo deste trabalho foi caracterizar parte dos fósseis exumados de um dos depósitos escavados, um abismo denominado Locus 3 , e compreender melhor os processos relacionados com a formação do pacote fossilífero. Para isso, o material fóssil foi analisado sob duas perspectivas: 1) como elementos esqueléticos, através da análise anatômica e taxonômica e 2) como bioclastos, através da análise tafonômica. Em ambos os casos também foram considerados aspectos da distribuição espacial dos fósseis. Os resultados da análise taxonômica indicaram a presença de 16 indivíduos de Tayassuidae, 9 de Cuniculus paca, 8 de Cervidae, 7 de Cuniculus major e 1 de Panthera onca. Considerando-se estes animais e aqueles identificados em outros trabalhos sobre o Locus 3 , a variedade taxonômica representada neste babismo é pequena, indicando uma forte seleção dos grupos incorporados. Com relação ao peso corporal, verificou-se a presença de animais de pequeno, médio e grande porte, sugerindo pouca seleção para esta característica. De acordo com a distribuição espacial dos remanescentes de meso e megamamíferos, os últimos foram depositados apenas mais recentemente, indicando que o potencial para o aprisionamento de animais do Locus 3 tornou-se mais abrangente ao longo do tempo. Os resultados da análise tafonômica indicam que a formação do depósito fossilífero foi complexa, envolvendo processos cuja ação foi muitas vezes simultânea e sobreposta. Dentre os processos analizados, a fragmentação foi o mais intenso, agindo desde a necrólise das carcaças até depois do soterramento final do material. O pisoteio foi identificado como o principal agente de fragmentação do material, seguido pela queda de animais e de blocos de calcário e pela compactação da coluna sedimentar. O intemperismo foi o segundo fator mais importante na alteração das condições originais do material. Este fator modificou a superfície dos ossos de todo o pacote fossilífero, sugerindo que a taxa 
de sedimentação no Locus 3 foi baixa. A abrasão, outro fator analisado, teve uma contribuição modesta na alteração do material, ocorrendo principalmente na superfície e devido à ação da água, que por sua vez foi importante para o retrabalhamento do material. Carnívoros e roedores também tiveram uma pequena contribuição na formação do pacote fossilífero. A distribuição espacial das peças remontadas indica predominância da dispersão de ossos em superfície e em diferentes momentos da formação do pacote fossilífero. Além disso, as mudanças pós-deposicionais dos sedimentos foram importantes para a dispersão vertical de peças remontadas. Por último, a natureza confinada do abismo, a alta densidade de fósseis e a baixa taxa de sedimentação favoreceram a mistura vertical e horizontal de ossos/dentes de diferentes indivíduos e táxons. A complexidade identificada na formação do depósito tem implicações para o estudo de sítios em cavernas, especialmente no que diz respeito ao uso da associação espacial de fósseis para subsidiar interpretações deposicionais e paleoambientais.

Palavras-chave: Lagoa Santa, Paleomastozoologia, Caverna, Carste, Contexto estratigráfico. 


\section{ABSTRACT}

The absence of information from the Brazilian Pleistocene mammalian fauna that goes beyond the taxonomic/descriptive studies and the lack of excavations with minimal stratigraphic control motivated the interventions in the Gruta Cuvieri (Lagoa Santa, Minas Gerais, Brazil) deposits applying a fine resolution excavation method. This method recorded in detail the spacial distribution of fossils as well as the sedimentologic context where the fossils were embedded, representing a pioneering foray to the national paleomastozoology. The objective of this work was to characterize part of the fossils exhumed from one of the excavated deposits, a pit named Locus 3 , and to better understand the processes related with the development of this fossiliferous package. In order to do so, I analyzed the fossil material under two perspectives: 1) as skeletal elements, through the anatomic and taxonomic analysis and 2) as bioclasts, through the taphonomic analysis. In both approaches I also considered aspects of the spacial distribution of fossils. The results of the taxonomic analysis indicate the presence of 16 individuals of Tayassuidae, 9 of Cuniculus paca, 8 of Cervidae, 7 of Cuniculus major and 1 of Panthera onca. Considering these animals and those identified in other studies of Locus 3 the taxonomic variety represented in this pit is small, indicating a strong selection of groups incorporated therein. With regard to body weight there was the presence of animals of small, medium and large size, suggesting little selection for this feature. According to the spacial distribution of the remains of meso and megamammals, the latter were deposited only more recently, indicating that the Locus 3 potential for trapping animals had become more inclusive over time. The results of the taphonomic analysis indicate that the formation of the fossiliferous deposit was complex, involving processes that were acting often simultaneously and superimposed. Among the processes evaluated, the fragmentation was the most intense, acting from the necrolysis of the carcasses to after the final burial of the material. Trampling was identified as the main agent of material fragmentation, followed by the fall of animals and limestone blocks and by the compression of the sedimentary column. Weathering was the second most important factor in altering the original condition of the material. This feature modified the surfaces of the bone remains all over the fossiliferous package, suggesting slow sedimentation rate in Locus 3. Abrasion, another factor analysed, had a modest contribution in shaping the material, occurring 
mainly in the surface and due to the action of water, which in turn was important for the reworking of the material. Carnivores and rodents had also a small contribution to the fossiliferous package formation. The spacial distribution of the refitted pieces indicates predominance of bones dispersion on surface and at different times of the fossiliferous package formation. In addition, the post-depositional changes of the sediments were important to the vertical dispersion of refitted pieces. Lastly, the confined nature of the pit, the high density of fossils and the slow sedimentation rate favored vertical and horizontal mixture of bones/teeth of different individuals and taxa. The complexity identified in the deposit formation has implications for the study of cave sites, especially with regard to the use of spacial fossils association to subsidize depositional and paleoenvironmental interpretations.

Key words: Lagoa Santa, Paleomastozoology, Cave, Karst, Stratigraphic context. 


\section{LISTA DE TABELAS}

2.1 - Grupos taxonômicos identificados e respectivos valores do total de espécimes (NISP) e do número mínimo de indivíduos (MNI); pg. 27.

2.2 - Principais resultados obtidos com as análises realizadas na seção 2.1 Grupos taxonômicos identificados; pg. 30.

2.3 - Médias e desvios padrão de medidas das fileiras dentárias e terceiros molares superiores de Cuniculus sp. do Locus 3 da Gruta Cuvieri e de Cuniculus major disponíveis na literatura; pg. 48.

2.4 - Medidas de hemimandíbulas de Cuniculus sp. e Cuniculus paca; pg. 49.

2.5 - Medidas dos ossos longos de Cuniculus sp. e Cuniculus paca; pg. 52.

2.6 - Medidas de escápulas, tálus e calcâneos de Cuniculus sp. e Cuniculus paca; pg. 56.

2.7 - Principais resultados obtidos com as análises realizadas na seção 2.2 - O registro fóssil do gênero Cuniculus; pg. 58.

3.1 - Principais resultados obtidos com as análises realizadas no Capítulo 3 Tafonomia. pg. 97 


\section{LISTA DE FIGURAS}

1.1 - Mapa da Área de Proteção Ambiental Carste de Lagoa Santa com a localização da Gruta Cuvieri e de outros sítios da região; pg. 4.

1.2 - Planta baixa e seção esquemática em escala da Gruta Cuvieri; pg. 5.

1.3 - Seções Norte - Sul das subdivisões A, B e C do Locus 3 da Gruta Cuvieri evidenciando a distribuição das fácies sedimentares nas quais os ossos estavam inseridos e as datações disponíveis; pg. 9.

1.4 - Croqui do testemunho norte do Locus 3A e do testemunho sul do Locus 3B, indicando feições erosivas no topo da sequência estratigráfica; pg. 12.

2.1 - Principais etapas do processamento realizado para converter os dados bidimensionais dos desenhos de campo em dados tridimensionais a serem utilizados no AutoCAD; pg. 25.

2.2 - Percentual de representação de cada grupo taxonômico identificado no Locus 3 e das peças não identificadas; pg. 27.

2.3 - Distribuição dos ossos de mamíferos de médio e grande porte exumados do Locus 3 da Gruta Cuvieri; pg. 29.

2.4 - Ossos cranianos e pós-cranianos de Cuniculus sp. e Cuniculus paca; pg. 45.

2.5 - Mapa de parte da região de Lagoa Santa, Minas Gerais, mostrando os sítios para os quais Cuniculus laticeps e Cuniculus major foram reportadas e cuja localização é conhecida; pg. 46.

3.1 - Vista de perspectiva sudeste da disposição dos fósseis exumados do Locus 3 da Gruta Cuvieri; pg. 70.

3.2 - Distribuição espacial dos fósseis de C. major, C. paca e Cervidae; pg. 71.

3.3 - Distribuição espacial dos fósseis de Tayassuidae, $P$. onca e de taxon indeterminado; pg. 74.

3.4 - Distribuição espacial dos ossos articulados e com lógica anatômica; pg. 77.

3.5 - Percentual de espécimes por parte anatômica para cada estado de fragmentação e considerando cada subdivisão do Locus 3 como uma totalidade; pg. 79. 
3.6 - Distribuição espacial dos ossos segundo o estado de fragmentação; pg. 81.

3.7 - Ossos com feições associadas ao intemperismo climático; pg. 83.

3.8 - Distribuição espacial dos ossos com feições associadas ao intemperismo climático; pg. 84.

3.9 - Ossos que apresentam sinais de abrasão; pg. 86.

3.10 - Distribuição espacial dos ossos com sinais de abrasão; pg. 87.

3.11 - Ossos que apresentam marcas produzidas por roedores; pg. 89.

3.12 - Distribuição espacial dos ossos com marcas produzidas por roedores; pg. 90.

3.13 - Ossos que apresentam marcas produzidas por carnívoros; pg. 92.

3.14 - Distribuição espacial dos ossos com marcas produzidas por carnívoros; pg. 93.

3.15 - Distribuição espacial das peças complementares (remontagem); pg. 95. 


\section{LISTA DE ANEXOS}

I - Procedimento para o conversão de dados bidimensionais em tridimensionais; pg. 142. 


\section{INTRODUÇÃO}

\subsection{A paleomastozoologia na região de Lagoa Santa}

A região de Lagoa Santa, Minas Gerais, apresenta grande potencial para a pesquisa paleomastozoológica. Já no início do século XIX trabalhadores que exploravam as cavernas da região em busca de salitre para fertilização do solo relatavam a presença de ossadas no interior de algumas cavidades (Paula Couto, 1970; Cartelle, 1994a). Posteriormente, trabalhos paleontológicos sistemáticos foram realizados pelo naturalista dinamarquês Peter Wilhelm Lund (1801-1880) na mesma região entre 1835 e 1843 (Paula Couto, 1970), reunindo a mais expressiva coleção de fósseis do Quaternário brasileiro (Kipnis, 1998). Lund analisou mais de 12.000 peças distribuídas em 100 gêneros e 149 espécies, dos quais 19 gêneros e 32 espécies são extintos (Cartelle, 1994a).

O valor dos dados gerados pelos trabalhos de Lund e pelos paleontólogos que o sucederam é imensurável. Entretanto, historicamente a paleontologia brasileira desenvolveu-se com um caráter anatomista/taxonomista (e.g. Alberdi et al. 2003; Cartelle, 1980, 1991, 1994a, 1994b, 1994c, 1998; Cartelle e Ferreira, 1994; Cartelle e luliis, 1995; Cartelle e Lessa, 1988; Cartelle e Mahecha, 1985; Cunha et al., 1985; Czaplewski e Cartelle, 1998; Góes et al., 2002; luliis e Cartelle, 1993, 1999; Magalhães et al., 1992; Paula Couto, 1953, 1970, 1971, 1975, 1977, 1979 e 1980), resultando no fato de que dos fósseis de Lagoa Santa depositados em museus, apenas uma pequena parcela é oriunda de escavações com um mínimo controle estratigráfico (Kipnis, 1998). 
Outra questão importante refere-se à cronologia dos depósitos fossilíferos de Lagoa Santa. A carência de datações absolutas associada às estratigrafias complexas (comumente encontradas no interior de cavernas da região; Auler, 2009) e o parco controle estratigráfico fornece em um panorama cronológico pouco preciso. Considerando que o Pleistoceno sul americano é melhor conhecido na Argentina (Paula Couto, 1975), têm sido efetuadas tentativas de correlação cronológica com a fauna extinta encontrada naquele país (Paula Couto, 1975; Cartelle, 1999). Porém, em função dos dois problemas mencionados (carência de datações e estratigrafia complexa) os depósitos fossilíferos nacionais são genericamente classificados como pertencentes ao Pleistoceno Terminal (Auler et al., 2003; Auler et al., 2006).

Os problemas estratigráficos e cronológicos mencionados impossibilitam a compreensão da relação temporal entre os fósseis e, conseqüentemente, limitam o desenvolvimento de pesquisas que extrapolem 0 material fóssil propriamente dito, como ocorre com os estudos tafonômicos e paleoecológicos. Com o intuito de colaborar para a elucidação destes problemas o Laboratório de Estudos Evolutivos Humanos (LEEH/USP), através do projeto temático "Origens e Microevolução do Homem na América: uma abordagem paleoantropológica III" (FAPESP Proc. 04/ 01321-6), adotou um método de escavação sistemático inédito na paleomastozoologia brasileira, tendo obtido recursos expressivos para datação do material recuperado. Munido destas ferramentas para caracterizar a estratigrafia e a cronologia dos restos fósseis, o LEEH/USP elegeu para suas escavações paleontológicas a Gruta Cuvieri.

A Gruta Cuvieri é uma pequena caverna, descrita em detalhe a seguir, 
que apresenta três abismos. Para compreender os diversos aspectos da gênese e da evolução de seus depósitos fossilíferos, o LEEH/USP tem promovido o desenvolvimento de pesquisas de cunho tafonômico pelo potencial que elas oferecem para a compreensão destes registros faunísticos. Entre elas está o presente trabalho cujo objetivo é diagnosticar anatômica e taxonomicamente parte dos fósseis de mamíferos exumados de um dos abismos, o Locus 3, bem como, caracterizar a dinâmica tafonômica que agiu sobre o material abordado e seu papel na formação do depósito fossilífero em questão. Tais objetivos subsidiam a busca de um cenário mais específico da formação do pacote fossilífero estudado aliando os resultados obtidos aqui e em estudos prévios desenvolvidos na gruta. Além disso, este projeto contribui diretamente para o conhecimento paleomastozoológico do Pleistoceno Final.

\subsection{A Gruta Cuvieri}

Situada na região norte do município de Matozinhos, Minas Gerais, a Gruta Cuvieri (Figura 1.1) encontra-se na Área de Proteção Ambiental Carste de Lagoa Santa e dista aproximadamente $60 \mathrm{Km}$ de Belo Horizonte. Esta pequena caverna desenvolveu-se na vertente nordeste de um pequeno maciço calcário localizado no fundo de uma dolina. Originalmente a Gruta Cuvieri apresentava duas entradas, porém, nos dias atuais a maior delas encontra-se obstruída por blocos abatidos. A entrada que permanece aberta tem aproximadamente $1,5 \times 1,0 \mathrm{~m}$ e adiante dela segue um conduto principal praticamente horizontal, baixo e relativamente curto (aproximadamente $15 \mathrm{~m}$ ), que termina, invariavelmente, em três abismos aparentemente sem conexão entre si. Estes abismos, chamados de Locus 1, 2 e 3 (o último subdividido de 


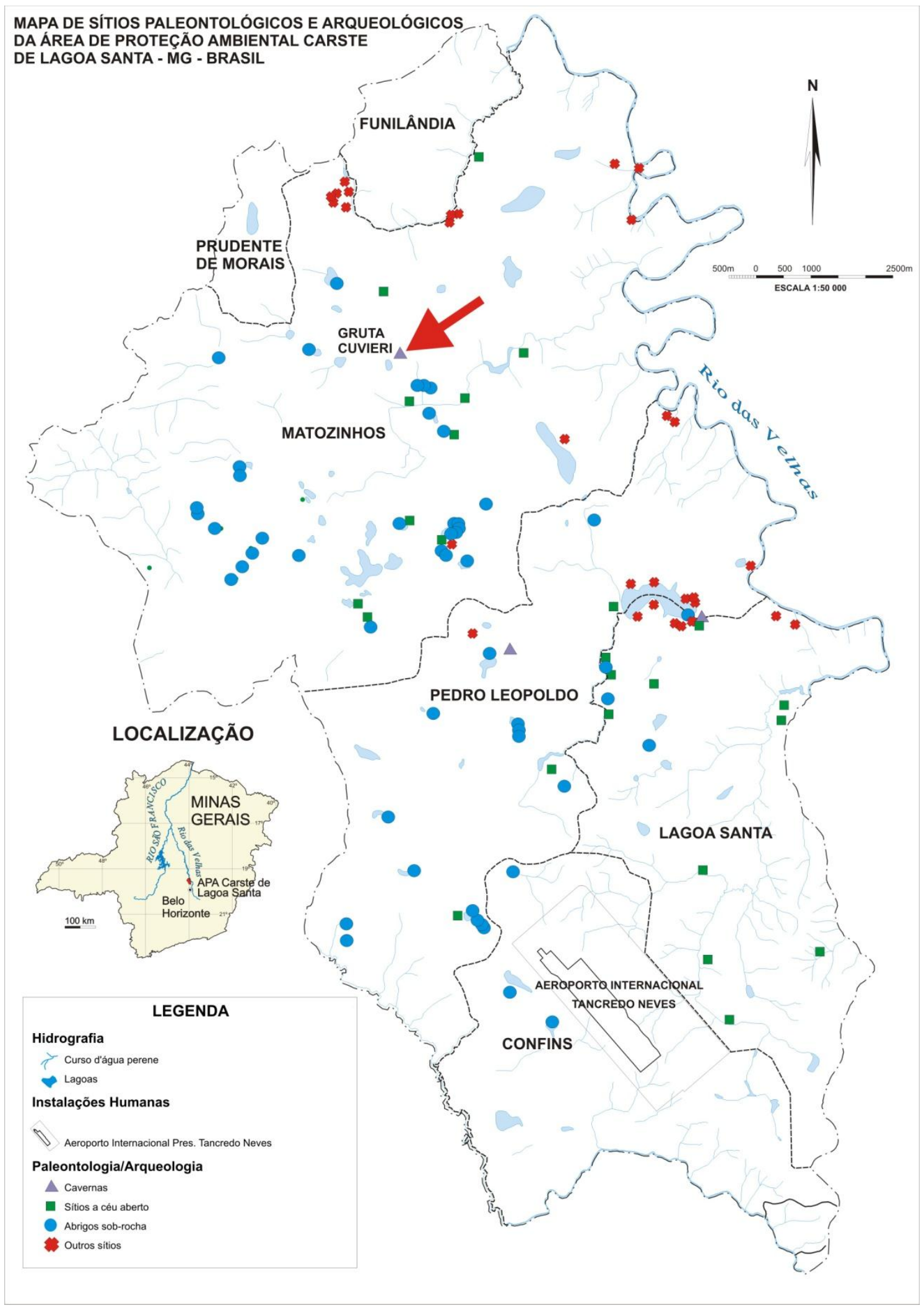

Figura 1.1 Mapa da Área de Proteção Ambiental Carste de Lagoa Santa com a localização da Gruta Cuvieri (seta vermelha) e de outros sítios da região. 


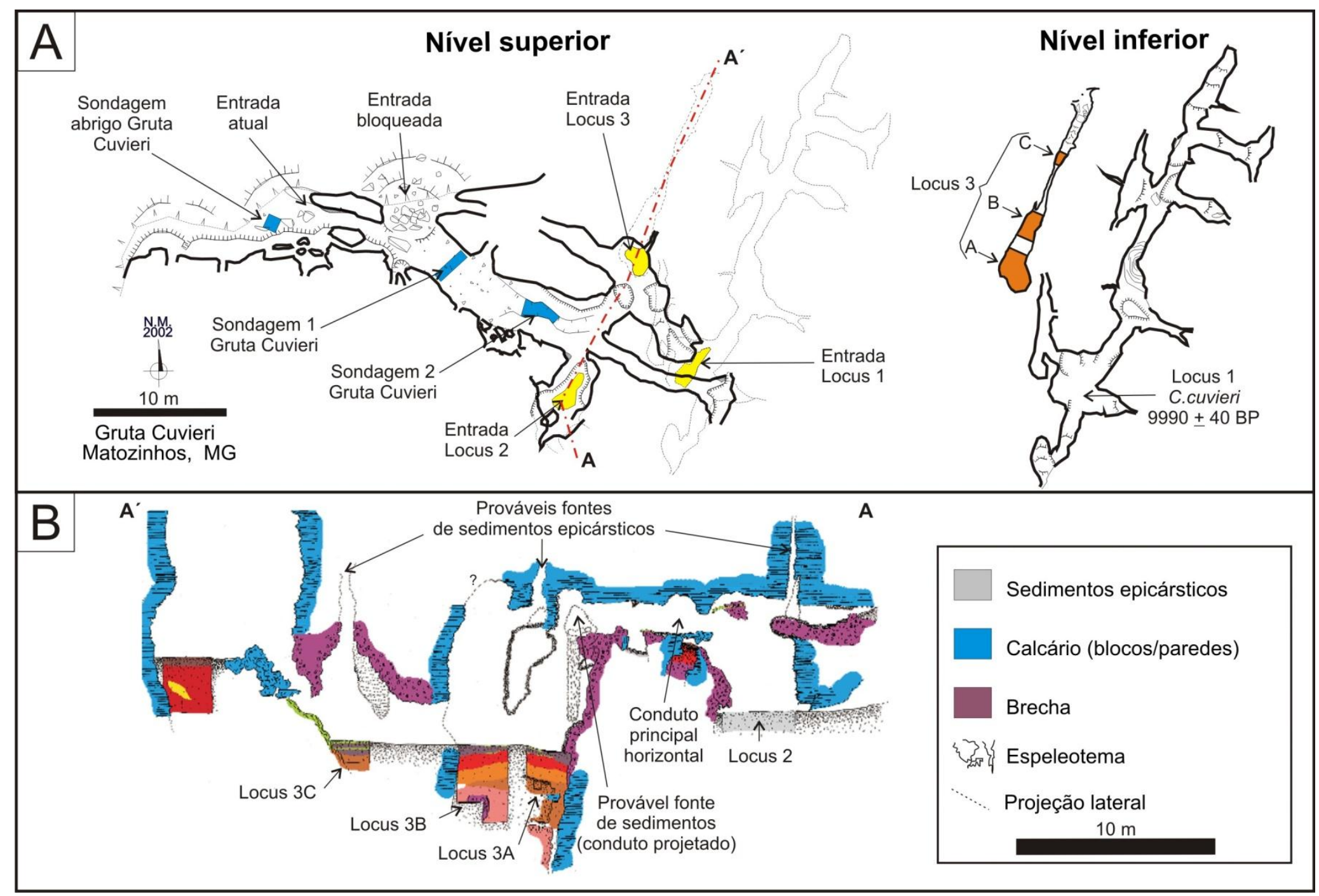

Figura 1.2 - Planta baixa (A) e seção esquemática em escala (B) da Gruta Cuvieri. Em A, no nível superior, as entradas dos abismos denominados Locus 1, 2 e 3 estão evidenciadas em amarelo e as sondagens em azul. Ainda em A, no nível inferior, é possível observar as subdivisões A, B e C do Locus 3 em laranja e o local onde Prous encontrou o esqueleto de Catonyx cuvieri. Em B observa-se a localização do Locus 3 em relação ás prováveis vias de entrada de sedimentos, bem como o espeleotema situado na entrada do Locus 3A. O plano da seção A-A'está indicado em A por uma linha tracejada vermelha. B foi adaptada de Haddad-Martim (2007). 
sul para norte em Locus: 3A, 3B e 3C; Figura 1.2), apresentam quedas verticais

de aproximadamente 16, 4 e 8 metros, respectivamente.

A Gruta Cuvieri apresenta algumas características distintas da maioria das cavernas da região. Em geral as cavernas de Lagoa Santa são predominantemente planas em seu interior e apresentam depósitos fossilíferos geralmente consolidados por cimentação carbonática (Neves e Piló, 2008). Já a Gruta Cuvieri apresenta abismos que funcionam como verdadeiras armadilhas naturais, tanto para a própria fauna cavernícola, quanto para animais que eventualmente adentram cavernas. Além disso, a maior parte dos sedimentos depositados nos abismos é friável (inconsolidado), permitindo a execução de escavações estratigraficamente controladas.

O valor paleontológico da Gruta Cuvieri foi constatado em 1974 quando o pesquisador André Prous e sua equipe encontraram uma preguiça extinta de médio porte (Catonyx cuvieri, Lund, 1839 ) que jazia de forma articulada e semi exposta na superfície do Locus 1. Em datação realizada pelo LEEH/USP em 2002 para este esqueleto obteve-se uma idade de $9990 \pm 40$ A.P. (idade radiocarbônica não calibrada; Beta \#165398; Piló e Neves, 2003; Neves e Piló, 2003; Figura 1.2). Apesar da descoberta realizada pela equipe de André Prous no Locus 1, as intervenções executadas pelo projeto temático na Gruta Cuvieri restringiram-se aos Loci 2 e 3. Esta decisão foi tomada por que a remoção do esqueleto da preguiça extinta resultou em intensa perturbação dos sedimentos depositados no Locus 1.

As escavações foram conduzidas através de uma adaptação da consagrada técnica arqueológica denominada decapagem por solos de ocupação. 
Este procedimento difere drasticamente daqueles empregados tradicionalmente nos estudos da paleomastozoologia brasileira. A decapagem consiste em remover sucessivas camadas da matriz sedimentar na qual os ossos estão inseridos, expondo-os até suas respectivas bases, com o objetivo de reconstituir a superfície original onde eles jaziam. Após a remoção dos sedimentos em toda a área do Locus delimitada para escavação ${ }^{1}$ mantendo as peças ósseas nos respectivos lugares, uma exposição está finalizada. Todos os ossos encontrados em cada exposição foram desenhados em papel milimetrado numa escala de 1:5, tendo como orientação aproximada os eixos norte, sul, leste e oeste, os quais permaneceram sinalizados no interior de cada loci durante todas as etapas de escavação. Em seguida foram tomados os valores de profundidade no centro do locus, em alguns pontos ao longo dos eixos e nas quatro extremidades (norte, sul, leste e oeste).

Depois de desenhada, cada peça encontrada in situ foi coletada e acondicionada individualmente em embalagem identificada com o respectivo número de referência. Os sedimentos removidos durante toda a escavação foram peneirados para localizar eventuais remanescentes ósseos neles contidos. Os ossos, dentes e fragmentos encontrados na peneira foram recolhidos e agrupados sob o número da exposição da qual provêm. É importante esclarecer que, posteriormente, selecionaram-se apenas as peças de peneira que eram, ao menos, identificáveis anatomicamente para que recebessem numeração independente daquela usada nos ossos recuperados in situ. Desta forma, uma grande quantidade de fragmentos cuja identidade anatômica (e taxonômica) não

1- Em cada um dos Loci foram mantidos testemunhos do pacote fossilífero original para observações estratigráficas e para que gerações futuras possam aplicar técnicas de escavação mais aprimoradas aos depósitos fossilíferos da gruta. 
pode ser determinada permaneceu sem numeração nas peneiras de praticamente todas as exposições.

A técnica de escavação aplicada registrou a disposição espacial dos ossos encontrados in situ de modo que, após a cura, é possível localizar a posição original de cada um deles. Isso possibilita estudos mais detalhados dos pacotes fossilíferos, fundamentando pesquisas tafonômicas.

Especificamente no Locus 3A, a partir de determinado ponto, a escavação por decapagem tornou-se inviável. Isto ocorreu principalmente por limitação espacial decorrente do afunilamento da área escavável e também pela ocorrência de sedimentos altamente cimentados (Figura 1.3; fácies 7c), acompanhados de relativa diminuição da quantidade de ossos. A partir daí, adotou-se, alternativamente, o método de escavação por níveis artificiais, mantendo ainda algum controle estratigráfico, mas não espacial. Neste procedimento cada exposição teve $5 \mathrm{~cm}$ de profundidade e todo o material escavado foi integralmente coletado como pertencente à peneira, com numeração independente daquela dos ossos encontrados in situ e sem desenhos da posição em que foram encontrados.

Uma característica marcante observada durante as escavações no Locus 3 é que ossos íntegros, em alguns casos em lógica anatômica, foram encontrados lado a lado com ossos fragmentados e pequenos fragmentos dispersos. No entanto, segundo Mayer (2007) os esqueletos articulados eram, em sua maior parte, pertencentes à megafauna, sendo que, entre os animais de pequeno e médio porte somente alguns mantiveram a organização anatômica de parte do esqueleto. 


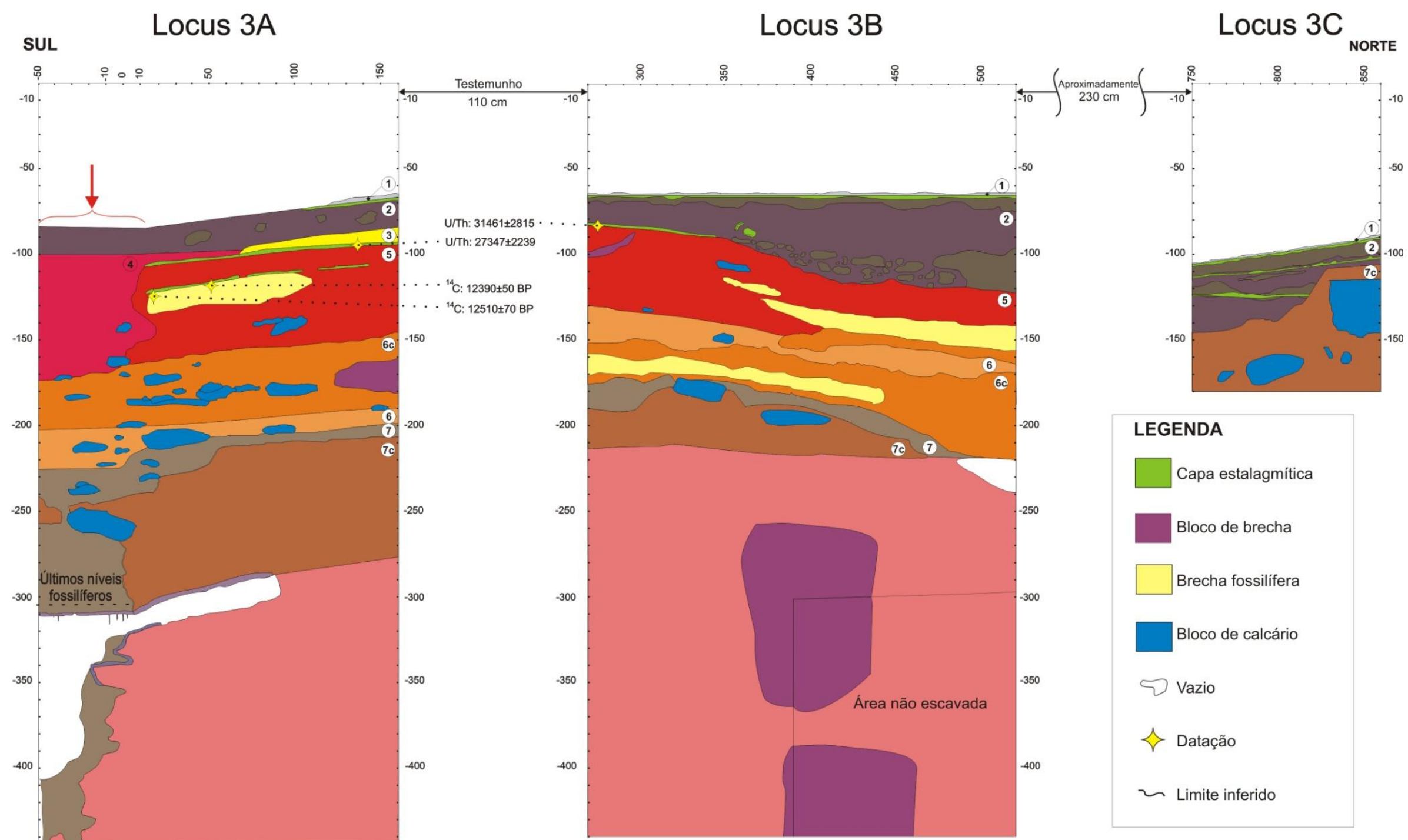

Figura 1.3 - Seções Norte - Sul das subdivisões A, B e C do Locus 3 da Gruta Cuvieri evidenciando a distribuição das fácies sedimentares nas quais os ossos estavam inseridos e as datações disponíveis. Em cada subdivisão as fácies estão identificadas na lateral direita por números e a letra c indica sedimento consolidado. A distância entre o Locus $3 A$ e o $3 B$ está representada proporcionalmente ao testemunho mantido entre estas áreas. Entre 3B e 3C a distância não é proporcional (aproximadamente $230 \mathrm{~cm}$ ). Observando as três unidades é possível perceber grande correspondência entre os sedimentos depositados nas áreas 3A e 3B. Porém, em 3C tal correspondência limita-se às camadas superiores. Figura adaptada de Haddad-Martim (2007). 
Além das áreas delimitadas para escavação no interior dos abismos, foram estabelecidas também duas sondagens no conduto principal e uma no abrigo da caverna (Figura 1.2). O objetivo destas sondagens foi verificar a presença de evidências que indicassem o transporte de material ósseo de fora para dentro da caverna por esta via, o que não foi constatado (Mayer, 2007; Hubbe, 2008).

Paralelamente ao desenvolvimento das escavações efetuaram-se apontamentos sobre as características dos sedimentos que envolviam os restos ósseos em cada exposição. Amostras destes sedimentos foram sistematicamente coletadas e caracterizadas. Para isso, utilizaram-se os critérios: coloração, cimentação e textura. Posteriormente as amostras foram analisadas mais profundamente por Haddad-Martim (2007) que abordou as amostras sedimentares com um conjunto de análises, incluindo: descrição morfológica, microscópica, granulométrica e geoquímica (esta última realizada por fluorescência de Raios-X). Suas análises resultaram na identificação de um considerável número de fácies sedimentares no Locus 3 ( $A, B$ e C) cujas distribuições estão representadas na Figura 1.3. O registro destas informações contribui para uma melhor contextualização dos restos ósseos recuperados, possibilitando investigar a influência de processos geológicos sobre a formação dos pacotes fossilíferos da caverna.

Haddad-Martim (2007) classificou detalhadamente as fácies, atribuindoIhes siglas para a respectiva identificação. Por conveniência, no presente trabalho substituíram-se estas siglas por números, os quais estão associados ás respectivas fácies na Figura 1.3, no interior de círculos. Aqueles sedimentos que se apresentavam consolidados durante as escavações têm a letra $c$ 
associada ao número da fácies a que representam (Figura 1.3).

Na Figura 1.3 é possível observar também que na região sul do Locus 3A existem algumas depressões nas fácies que potencialmente caracterizam feições erosivas. A ocorrência destas feições coincide verticalmente com uma depressão natural encontrada na superfície do pacote fossilífero antes do início das escavações e, por isso, esta área do locus, incluindo as fácies mais profundas, é chamada aqui de área das bacias (Figura 1.3; indicada por uma seta vermellha). Nesta região do locus existem duas vias potenciais para a entrada de água. Uma delas é o conduto principal que conecta o Locus 3 à dolina em frente à caverna e a outra é um conduto lateralmente projetado no teto da caverna, bem acima da entrada do Locus 3 (Figura 1.2, B).

Segundo Haddad-Martim (2007) a circulação de água no Lócus 3 foi intensa e várias alterações pós deposicionais observadas nas fácies ali escavadas são atribuídas a oscilações do regime hídrico/lençol freático, a gotejamentos e a escorrimentos de água pelas paredes. Esta informação é reforçada pelo fato de que, em geral, as cavernas se configuram como ambientes confinados e por isso experimentam dramáticas variações na amplitude vertical do nível de água (Auler, 2009).

No contato entre as fácies 2 e 5 existe outro indício de que uma dinâmica hidrológica relativamente intensa agiu no Locus 3 (Figura 1.4). Ele pode ser verificado no testemunho norte do Locus $3 \mathrm{~A}$ e, mais claramente, no testemunho sul do Locus 3B. Trata-se de uma feição erosiva que lembra um canal com forma irregular na parte superior do primeiro testemunho e que assume formato acanalado no segundo (Figura 1.4; Haddad-Martim, 2007). 


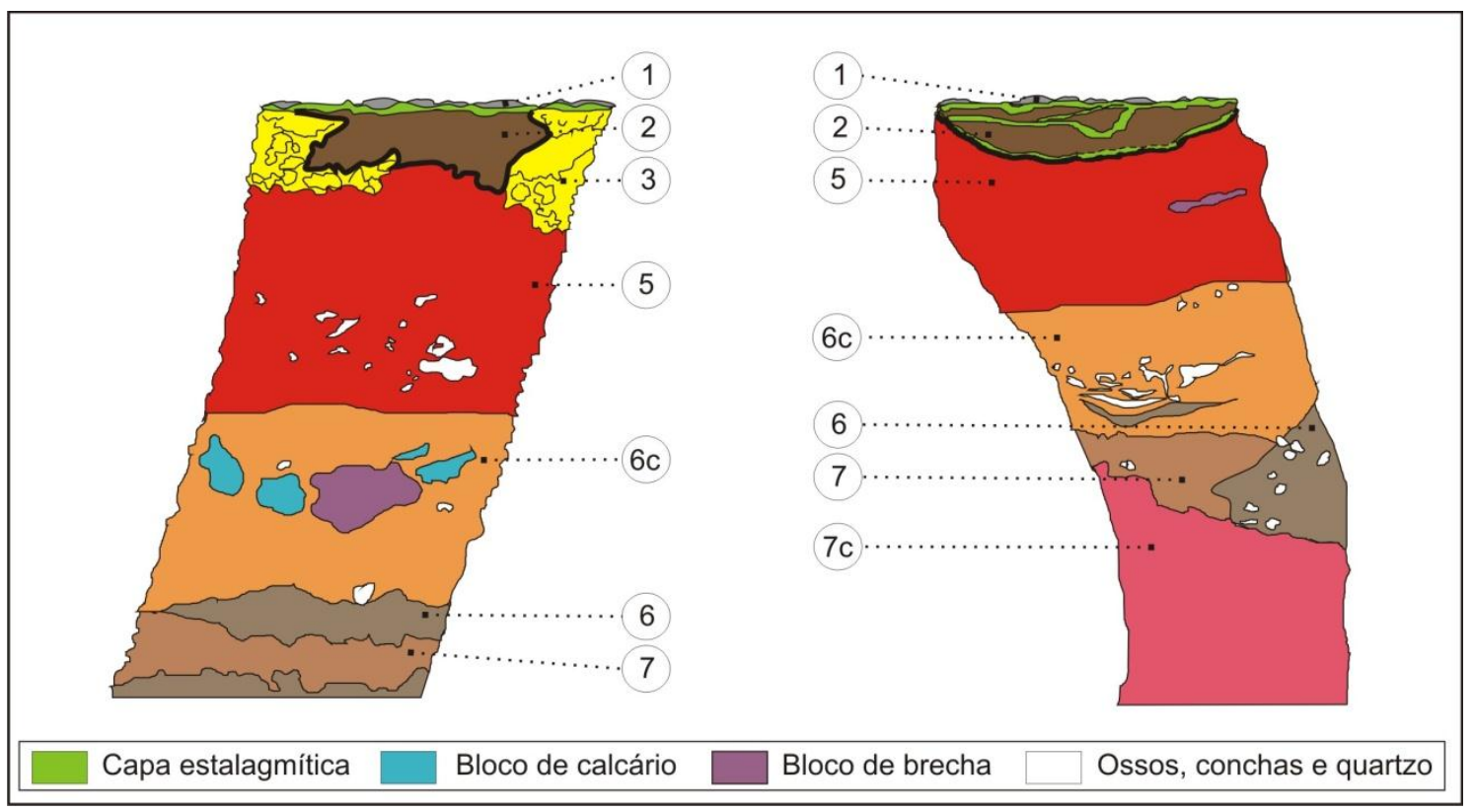

Figura 1.4 - Croqui do testemunho norte do Locus $3 \mathrm{~A}$, à esquerda, e do testemunho sul do Locus 3B, à direita, indicando as feições erosivas no topo da sequência estratigráfica com linhas pretas mais espessas. As fácies estão indicadas pelos respectivos números. A letra $c$ associada ao número da fácies indica sedimento consolidado. Figura adaptada de Haddad-Martim (2007).

As capas estalagmíticas encontradas, principalmente associadas às fácies superiores do Locus 3, também representam evidências a favor de alta umidade no Locus 3 (Figura 1.3). Além destas, outros indícios sobre a atividade hídrica foram registradas no diário de campo e tratam-se de uma marca de água nas paredes do locus, a poucos centímetros acima da superfície originalmente encontrada no local, e de uma vértebra presa na parede a aproximadamente dois metros de altura em relação à superfície do Locus 3C, supostamente transportada por água.

Embora o Locus 3 apresente várias evidências da ação de água durante sua formação, muito provavelmente não se trata de fluxos correntes e duradouros, pois ao investigar tafonomicamente os restos de megafauna exumados deste abismo, Hubbe (2008) não verificou ossos com sinais de abrasão de forma generalizada. É importante ressaltar que os animais 
analisados por Hubbe (2008; Tapirus terrestris, Linnaeus, 1758; Catonyx cuvieri, Lund 1840 e Valgipes bucklandii, Cartelle et al., 2009) apresentam tamanho corporal muito superior ao da maioria dos animais enfocados neste trabalho. Como o tamanho de um osso tem papel determinante em sua suscetibilidade a processos tafonômicos (como fragmentação e transporte; Shipman, 1981; Lyman, 1994), mesmo sem indícios de fluxos de água correntes e constantes para este material, existe a possibilidade de que os ossos de mesomamíferos recuperados no Locus 3 apresentem-se mais alterados em decorrência da ação d'água do que os de megafauna.

No que tange à cronologia do Locus 3, poucas idades estão disponíveis até o momento e o panorama fornecido por elas é complexo e problemático. De um total de 14 amostras ósseas enviadas para datação por C14-AMS, apenas duas $(\sim 14 \%)$, localizadas exclusivamente no Locus $3 \mathrm{~A}$, apresentaram condições adequadas para que a técnica fosse aplicada (Figura 1.3). Ao considerar o desvio padrão de tais datas, Hubbe (2008) constatou que elas apresentam sobreposição, não havendo diferença cronológica entre os espécimes datados. Foram realizadas também três datações por ${ }^{230} \mathrm{Th} /{ }^{234} \mathrm{U}$ para capas estalagmíticas nos Loci 3A e 3B (Figura 1.3). De acordo com Hubbe (2008), apesar da aparente diferença entre as datas obtidas para a capa estalagmítica, ao considerar a margem de erro envolvida verifica-se que também existe sobreposição entre elas. Como pode ser observado na Figura 1.3, a capa estalagmítica encontrava-se acima das amostras datadas por C14AMS, revelando uma incongruência entre as idades obtidas pelos diferentes métodos. Desta forma, segundo o método do C14-AMS os espécimes datados tem idade absoluta de aproximadamente 12.500 anos, ao passo que a datação 
sobre calcita sugere uma idade mínima de 29.000 anos.

\subsection{Tafonomia e a distribuição espacial de fósseis}

Tradicionalmente a paleontologia tem estudado dois aspectos dos materiais fósseis: a anatomia e a taxonomia (Shipman, 1981). Em 1940, Ivan Antonovich Efremov, paleontólogo russo, propôs um novo ramo da paleontologia: a tafonomia. Segundo seu proponente, este campo da paleontologia se ocupa do estudo detalhado da transição de restos orgânicos entre a biosfera e a litosfera (Efremov, 1940), sendo as raízes gregas do termo: tafos $=$ sepultamento; e nomos = leis (Holz e Simões, 2002). Portanto, por definição, no âmbito da tafonomia os restos orgânicos são vistos como partículas sedimentares (bioclastos) sujeitas aos mesmos processos daquelas de origem geológica (litoclastos), como erosão e transporte (Holz e Simões, 2002).

O conceito de tafonomia surgiu e desenvolveu-se na paleontologia (Shipman, 1981), sendo que primeiramente ela foi considerada uma subdisciplina da paleoecologia (Behrensmeyer e Kidwell, 1985). A tafonomia foi concebida com duas subdivisões: a bioestratinomia, que envolve os processos desde a morte de um organismo até seu soterramento final (considerando que um fóssil fica exposto antes de ser soterrado e pode ser re-exposto e resoterrado por repetidas vezes); e a diagenética, que abrange desde o soterramento final até a exumação do fóssil (Lyman, 2010). Algumas subdivisões foram incluídas em seguida, como a tectônica e a paleoecologia (Holz e Simões, 2002). Posteriormente, alguns autores argumentaram que os procedimentos de amostragem durante as escavações e a análise em 
laboratório, incluindo a cura do material, também devem ser considerados pela tafonomia (Behrensmeyer, 1984; Behrensmeyer e Kidwell, 1985). Isto por que tais atividades potencialmente implicam na introdução de vieses nas coleções (Behrensmeyer, 1984; Behrensmeyer e Kidwell, 1985).

Em 1985, Behrensmeyer e Kidwell enfatizaram que historicamente as pesquisas tafonômicas tinham seu foco na perda de informação paleontológica e no conseqüente viés decorrente disso. Estas autoras postularam, então, que a pesquisa na área da tafonomia deve envolver "os processos de preservação e como eles afetam a informação do registro fóssil" (Behrensmeyer e Kidwell, 1985). Elas argumentaram que os processos tafonômicos não apenas removem informações do registro fóssil, mas também lhe acrescentam-nas (Behrensmeyer e Kidwell, 1985).

Mais tarde, Behrensmeyer e colaboradores (2000) pontuaram que a tafonomia objetiva "compreender os processos [que influenciaram restos orgânicos] para que os dados do registro fóssil sejam avaliados corretamente e aplicados a problemas paleobiológicos e paleoecológicos". Recentemente, Lyman (2010) destacou que as retificações do conceito de tafonomia têm sido bem aceitas por outros pesquisadores e isso reflete uma crescente sofisticação do escopo da disciplina. Isso contribuiu para que a acepção do termo tafonomia se desenvolvesse de "conjunto de processos que enviesam a informação do registro fóssil" para o reconhecimento de que "os processos em si são dignos de pesquisa para responder questões paleobiológicas" (Lyman, 2010).

Apesar do desenvolvimento do conceito de tafonomia, o problema central desta disciplina, a equifinalidade, permanece o mesmo: processos 
diferentes podem ter resultados similares (Lyman, 1994a). Desta forma, muitas vezes não é possível identificar um processo específico responsável por determinado padrão, mas o conjunto de processos que podem produzi-lo.

Muitos estudos têm enfocado os processos post mortem atuantes no comportamento de bioclastos recentes e fósseis sob uma gama de condições biológicas, hidráulicas e químicas (Kidwell, 1985; 1986). Por outro lado, existe uma carência de trabalhos que avaliem as conseqüências que estes processos ocasionam na distribuição dos fósseis (Kidwell, 1985; 1986). Desta forma, considerando que os processos responsáveis pela acumulação de ossos em um determinado sítio podem resultar em padrões característicos de distribuição destes bioclastos em meio aos sedimentos (Shipman, 1981), a análise destes padrões apresenta grande potencial para compreender os eventos que levaram à formação de um depósito fossilífero (Shipman, 1981; Kidwell, 1985; 1986; Lyman 1994a).

Segundo Shipman (1981), na paleontologia os dados necessários à análise espacial de fósseis começaram a ser coletados na década de 1960, enquanto na arqueologia o registro espacial é mais freqüente. Como mencionado anteriormente, no Brasil a paleontologia enfoca tradicionalmente a abordagem anatômica/taxonômica dos fósseis, de maneira que a tafonomia representa uma ciência relativamente nova no país (Holz e Simões, 2002) . Em função disso, no contexto nacional as escavações paleontológicas com controle estratigráfico rígido são raras, e conseqüentemente, os estudos que consideram a distribuição espacial dos fósseis também o são.

Visando contribuir para o avanço deste novo campo no país, a partir dos dados da distribuição espacial dos fósseis e das informações sedimentológicas 
coletadas durante as escavações na Gruta Cuvieri, o presente trabalho investiga os restos ósseos exumados sob duas perspectivas: 1) a de elementos esqueléticos, através da análise anatômica e taxonômica e 2) a de bioclastos, através da análise tafonômica, ambas considerando algum aspecto da distribuição espacial dos fósseis. Cada uma destas abordagens está contida em um capítulo juntamente com os respectivos materiais e métodos, resultados e discussões. Em seguida são apresentadas as conclusões e considerações finais do trabalho. Em decorrência da identificação de um animal extinto pouco conhecido incluiu-se uma seção sobre este táxon no capítulo dedicado à taxonomia. 


\section{CURA E IDENTIFICAÇÃO DO MATERIAL}

\subsection{Grupos taxonômicos identificados}

\section{Introdução}

Anteriormente a qualquer análise o material paleontológico deve ser devidamente curado. Feito isso, a informação primordial de estudos desta natureza advém da identificação anatômica e taxonômica do material em questão. Somente após estas etapas é possível conduzir análises subseqüentes com a devida clareza. Por isso, ao longo desta seção apresentam-se as considerações sobre a cura do material e as análises de natureza anatômica e taxonômica desenvolvidas sobre os restos fósseis abordados neste trabalho. Apresenta-se também, a distribuição espacial dos fósseis analisados aqui e daqueles identificados em Hubbe (2008) que também se desenvolveu sobre material exumado do Locus 3 da Gruta Cuvieri.

\section{Material}

Neste trabalho considerou-se os restos ósseos plotados e de peneira dos mamíferos de médio porte ( $>5 \mathrm{e}<44 \mathrm{~kg}$ ) do Locus 3 da Gruta Cuvieri e aos restos de um indivíduo da megafauna ( $>44 \mathrm{~kg}$ ) exumado no Locus 3B e que não foi contemplado em Hubbe (2008). Foram considerados também fragmentos não identificados anatômica e taxonomicamente, pois somente a partir do total de peças é possível estimar quanto cada grupo taxonômico representa, percentualmente, do total da amostra.

Os restos curados e analisados totalizam 6140 peças, sendo 3069 recuperadas do Locus $3 \mathrm{~A}$ e 3071 do Locus 3B. O material do Locus $3 \mathrm{C}$ não foi 
considerado, pois se encontra acentuadamente fragmentado e envolto por uma matriz sedimentar extraordinariamente carbonatada. Tal cobertura demonstrouse de difícil remoção, não permitindo a análise dos ossos por ela envoltos.

Como mencionado anteriormente, outra parte do material fóssil do Locus 3 foi analisada previamente por Hubbe (2008). Em seu trabalho ele identificou quase a totalidade dos restos de megafauna do Locus 3, e por isso, seus resultados serão considerados ao longo do presente estudo.

Os desenhos das exposições (plotagens dos ossos) feitos durante as escavações serviram de base para a elaboração da reconstituição virtual da distribuição espacial dos fósseis aqui apresentada. Por este motivo, tal reconstituição restringiu-se às peças plotadas. Para assegurar a clareza sobre como se deu o processamento dos desenhos das exposições, o qual é descrito adiante em Método, estas ilustrações são descritas em detalhe a seguir.

Os desenhos de todas as exposições foram feitos a grafite sobre papel milimetrado, formato $A 3$, em escala 1:5, e são compostos por quatro folhas na maioria das exposições do Locus 3A e por duas no caso do Locus 3B. No total, foram consideradas 66 exposições do Locus 3A e 55 do Locus 3B, somando 374 folhas. Cada folha representa uma determinada área do Locus, de maneira que, quando justapostas, elas abrangem toda a superfície escavada. $O$ posicionamento das folhas foi orientado de maneira aproximada pelos eixos norte, sul, leste e oeste e por uma origem situada na intersecção destes eixos, analogamente aos eixos representados de maneira fixa no interior do Locus 3. Cada eixo, tanto nos desenhos, quanto no interior do Locus 3, foi graduado a cada dez centímetros com valores positivos no sentido norte e leste e negativos no sentido sul e oeste. Durante as escavações a profundidade de cada 
exposição foi registrada na origem e em alguns pontos ao longo dos eixos representados no croqui. O desenho dos restos ósseos escavados em cada exposição foi realizado em vista de planta e referenciando-se pelos eixos representados em cada folha.

\section{Método}

A cura do material seguiu a proposta sugerida por Neves (1988), salvo pequenas alterações. O processo todo consistiu basicamente em limpeza dos ossos a úmido, secagem, numeração e organização por partes anatômicas.

As peças que se apresentavam recobertas por concreções carbonáticas que obliteravam características necessárias à diagnose taxonômica foram selecionadas para a remoção desta cobertura. As concreções foram removidas segundo um protocolo desenvolvido pela equipe do LEEH/USP e que se divide basicamente em cinco etapas: 1) remoção mecânica com ferramentas diversas, 2) remoção química usando solução de ácido acético, 3) imersão em água para eliminar os resíduos do ácido, 4) secagem e 5) numeração de eventuais ossos/fragmentos contidos nos blocos de concreção.

A primeira delas concentrou-se na remoção mecânica dos conglomerados carbonáticos e foi efetuada com o auxílio de um conjunto de instrumentos, como alicates, martelos, ponteiras e exploradores. A remoção mecânica teve papel importante por eliminar grandes volumes de concreções em relativamente pouco tempo quando comparada ao tratamento químico. Este procedimento foi aplicado apenas em grandes volumes de concreção quando estavam seguramente distantes da superfície óssea, para evitar danos aos fósseis. Desta forma, mesmo com a remoção mecânica as peças ainda 
careceram de procedimentos adicionais.

Na segunda etapa as peças foram introduzidas em uma solução de água e ácido acético em concentração 10\%. Esta etapa teve duração bastante longa (em média 6,5 horas/peça) em função da grande quantidade de concreção aderida aos ossos. As peças foram inspecionadas individualmente a cada uma hora para verificar se as concreções tinham sido satisfatoriamente removidas. Caso isso ainda não tivesse ocorrido, a peça era mantida na solução ácida. Após a devida dissolução das concreções, em alguns casos, verificou-se que aquilo que foi inicialmente coletado como uma única peça agregava, na verdade, mais de um osso/fragmento ósseo. Os respectivos ossos/fragmentos foram mantidos agrupados durante todo o processo de remoção de concreções sob a identificação da peça original para posterior numeração complementar, após a secagem.

Quando os restos fósseis apresentaram-se devidamente livres da cobertura carbonática iniciou-se a terceira etapa. Os ossos foram retirados da solução ácida, receberam um rápido banho em água corrente e foram introduzidos em recipientes contendo somente água para que liberassem os resíduos do ácido acético que os impregnava. Mesmo com a troca sucessiva da água nos recipientes, a eliminação do ácido remanescente ocorreu de maneira muito lenta, consumindo, no mínimo, duas vezes mais tempo do que aquele durante o qual os ossos estiveram expostos à solução de ácido acético (em média 15 horas/peça).

$\mathrm{Na}$ quarta etapa os ossos foram retirados da imersão em água e acondicionados em gavetas com fundo de tela plástica para que secassem protegidos da luz solar e na ausência de temperaturas artificiais. Assim, 
segundo as variações da temperatura ambiente, os ossos levaram mais ou menos tempo para secar.

Durante a quinta etapa as peças que revelaram mais de um osso/fragmento agregados pelas concreções foram identificadas com a numeração da peça original e um complemento segundo ordem alfabética, por exemplo, CV L3B 10A e CV L3B 10B. Os fragmentos associados entre si foram então acondicionados conjuntamente e, após isso, o material encontrava-se, finalmente, pronto para ser analisado.

Para categorizar os táxons estudados quanto ao porte este trabalho valeu-se das classes de tamanho utilizadas em Alcover et al., (1998; pequenos mamíferos $<5 \mathrm{~kg}$, médios $>5 \mathrm{~kg} \mathrm{e}<44 \mathrm{~kg}$ e grandes $>44 \mathrm{~kg}$ ). Para informações adicionais, como peso aproximado dos táxons e hábitos alimentares considerou-se o trabalho de Eisenberg e Redford (1999).

A nomenclatura anatômica adotada para identificar os remanescentes ósseos do Locus 3 é a utilizada por Paula Couto (1979). A classificação taxonômica dos animais viventes foi realizada de acordo com Wilson e Reeder (2005) e a dos extintos de acordo com Lund (em tradução de Paula Couto, 1950). A diagnose taxonômica dos restos ósseos foi realizada através da consulta à Coleção de Referência Osteológica Renato Kipnis do LEEH/USP e também à coleção do Museu de Zoologia da Universidade de São Paulo (MZUSP). No caso específico dos táxons extintos recorreu-se, além da coleção de referência, à descrição efetuada por Lund (em tradução de Paula Couto, 1950).

A quantificação dos restos estudados foi realizada com o uso de índices de abundância. Na literatura há um intenso debate relativo à precisão destes 
índices (Badgley, 1986a; Badgley, 1986b; Gilinsky e Bennington, 1994; Grayson, 1984; Klein e Cruz-Uribe, 1984; Lyman, 1994a; Lyman, 1994b). Entre os mais comumente utilizados encontram-se o NISP - número de espécimes ${ }^{1}$ identificados por táxon - e o MNI - número mínimo de indivíduos de cada táxon necessário para contabilizar o elemento esquelético ${ }^{2}$ mais abundante (Grayson, 1984; Badgley, 1986a; Badgley, 1986b). Como observaram Klein e Cruz-Uribe (1984) e Badgley (1986a e 1986b), o NISP é muito sensível à fragmentação e por isto tende a superestimar o total de indivíduos, ao contrário do que ocorre com o MNI. Desta forma, como argumentado por Hubbe (2008), o MNI é o índice que melhor se adéqua para contabilizar o número de indivíduos exumado no Locus 3. Já o NISP será utilizado para contabilizar o total de espécimes pertencentes a cada táxon, assim como, os espécimes cujo táxon é indeterminado.

A fim de contrastar a distribuição espacial dos táxons aqui estudados com aqueles identificados previamente por Hubbe (2008; megafauna) no interior do mesmo pacote fossilífero, adaptou-se a plotagem dos restos de megafauna elaborada por este autor ao formato adotado no presente trabalho. Para isso, os arquivos originais de Hubbe (2008; elaborados em CorelDRAW ${ }^{R}$ ) foram salvos no formato $d w g$, tornando-se assim, compatíveis com o programa AutoCAD ${ }^{R}$, utilizado na reconstituição virtual da distribuição espacial dos fósseis realizada no presente estudo. A partir disso, corrigiu-se a escala do desenho de Hubbe (2008) para torná-lo compatível com as figuras do presente trabalho.

Uma vez que o AutoCAD ${ }^{R}$ simula um ambiente tridimensional, o

1- O termo espécime refere-se a um osso, dente ou fragmento de ambos.

2- $O$ termo elemento esquelético designa uma unidade natural do esqueleto que pode estar representada por vários espécimes caso estes sejam fragmentos. 
procedimento adotado para processar os dados bidimensionais dos desenhos das exposições exigiu uma longa série de atividades. A Figura 2.1 exibe de maneira simplificada os principais passos de cada etapa deste processamento, sendo que o procedimento completo encontra-se detalhadamente descrito no Anexo I. 


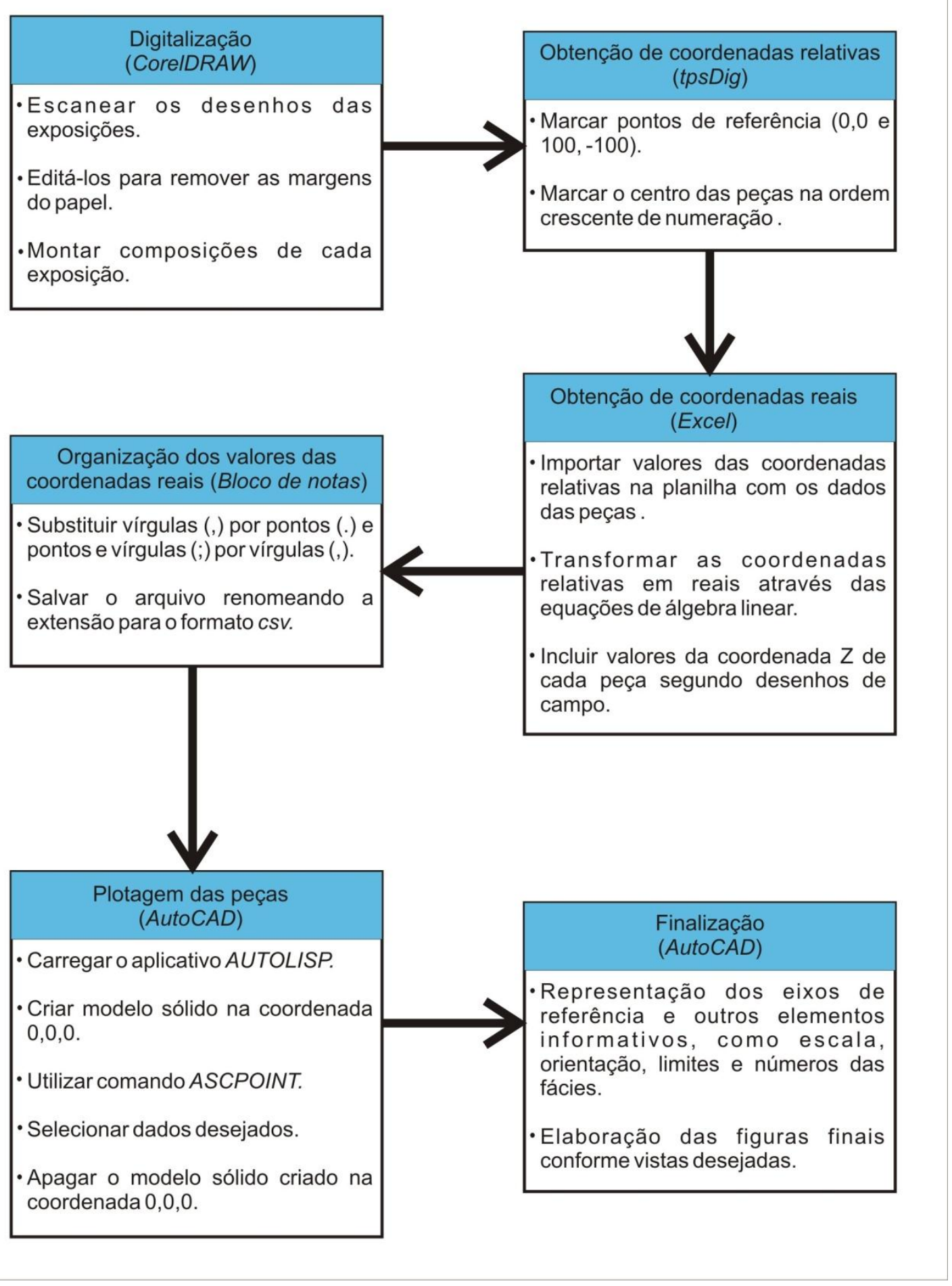

Figura 2.1 - Principais etapas do processamento realizado para converter os dados bidimensionais dos desenhos de campo em dados tridimensionais a serem utilizados no AutoCAD. Acima de cada quadro constam a denominação das etapas e o programa utilizado na maior parte dos itens de cada etapa, entre parênteses. Para detalhes ver Anexo I. 


\section{Resultados}

Os grupos taxonômicos identificados, os resultados do cálculo dos índices NISP e MNI, os hábitos alimentares e a massa corporal aproximada dos animais estão expressos na Tabela 2.1 , sendo que os valores percentuais de NISP constam na Figura 2.2. Foram identificados cinco grupos taxonômicos, sendo duas famílias, Tayassuidae, Palmer, 1897 e Cervidae, Goldfuss, 1820, um gênero, Cuniculus sp., Brisson, 1762, e duas espécies Cuniculus paca, Linnaeus, 1766 e Panthera onca, Linnaeus, 1758. Com exceção desta última, todos os táxons ocorrem no Locus 3A e 3B. Como a subdivisão do Locus 3 foi definida arbitrariamente em decorrência da delimitação das áreas de escavação, ambas as partes (3A e 3B) fazem parte do mesmo pacote fossilífero e a composição taxonômica será analisada considerando esta unidade.

É possível observar na Tabela 2.1 e na Figura 2.2 que 2625 peças não puderam ser identificadas taxonomicamente, o que representa pouco mais de 42\% da amostra (Tabela 2.1 e Figura 2.2). Observa-se também que os taiassuídeos contabilizam 1687 peças, as quais representam mais de $27 \%$ do total, e no mínimo, 16 indivíduos. Cuniculus sp., apresenta o segundo maior número de peças identificadas, 740. Estas peças equivalem a aproximadamente $12 \%$ do total e representam ao menos 7 indivíduos deste roedor (Tabela 2.1 e Figura 2.2).

Em seguida, os cervídeos reúnem 508 peças que totalizam pouco mais de $8 \%$ do total e pelo menos 8 indivíduos (Tabela 2.1 e Figura 2.2). $\mathrm{Na}$ seqüência, encontram-se as pacas viventes, C. paca, com 324 peças identificadas e que equivalem a cerca de $5 \%$ do total, representando no mínimo 9 indivíduos (Tabela 2.1 e Figura 2.2). Com o menor número de espécimes 
Tabela 2.1 - Grupos taxonômicos identificados e respectivos valores obtidos com o cálculo dos índices de abundância NISP e MNI, hábitos alimentares e massa corporal aproximada dos animais, segundo Eisenberg e Redford (1999).

\begin{tabular}{ccccc}
\hline Táxon & NISP & MNI & Hábitos alimentares & $\begin{array}{c}\text { Massa } \\
\text { corporal } \\
\text { (Kg) }\end{array}$ \\
Tayassuidae & 1687 & 16 & Onívoro & $20-35$ \\
Cuniculus sp. & 740 & 7 & Herbívoro (frugívoro, granívoro e folívoro) & $?^{*}$ \\
Cervidae & 508 & 8 & Herbívoro (pastador) & $25-35$ \\
C. paca & 324 & 9 & Herbívoro (frugívoro, granívoro e folívoro) & 10 \\
P. onca & 87 & 1 & Carnívoro & $61-119$ \\
Artiodactyla & 75 & - & - & - \\
Cuniculidae & 94 & - & - & - \\
Indeterminado & 2625 & - & - & - \\
Total & 6140 & 41 & - & - \\
\hline
\end{tabular}

*Não se tem conhecimento de estimativas da massa corporal do animal.

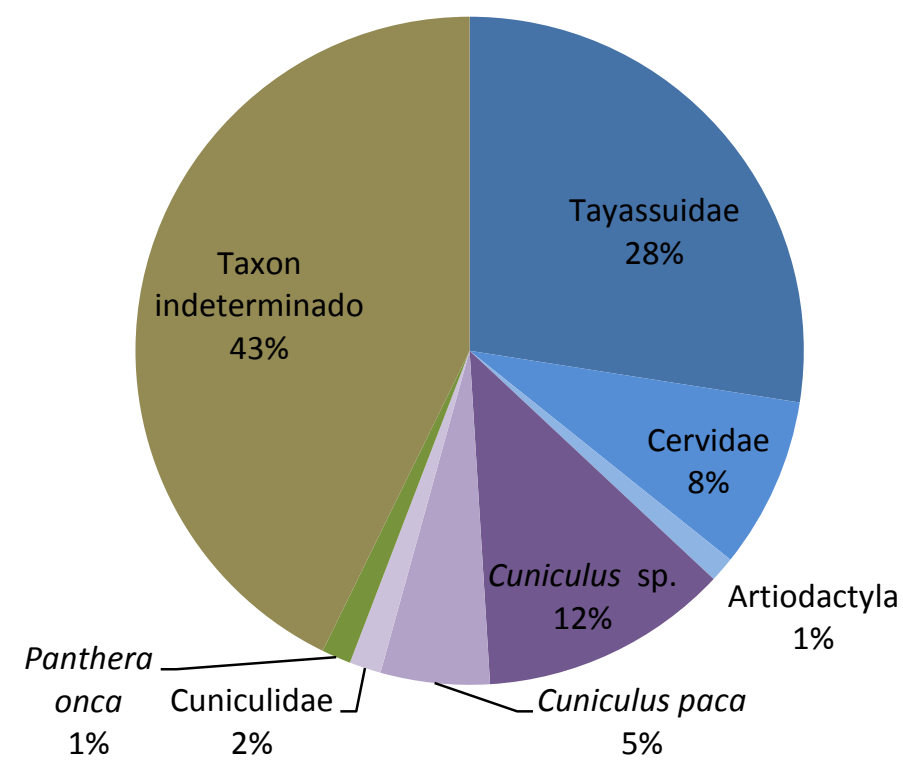

Figura 2.2 - Percentual de representação de cada grupo taxonômico identificado no Locus 3 e das peças não identificadas. Em Artiodactyla estão ossos que podem pertencer tanto a Tayassuidae, quanto a Cervidae. Em Cuniculidae contabilizou-se os ossos que podem pertencer a Cuniculus paca ou a Cuniculus sp. 
identificados taxonomicamente está $P$. onca, com 87 peças que totalizam pouco menos de 1,5\% do montante e representam ao menos 1 indivíduo (Tabela 2.1 e Figura 2.2). As peças que não puderam ser distinguidas entre Tayassuidae e Cervidae foram atribuídas a Artiodactyla, Owen, 1848 e somam pouco mais que 1\% do total (Figura 2.2). Da mesma forma, peças de Cuniculus paca e Cuniculus sp., quando indistinguíveis quanto à espécie, foram atribuídas a Cuniculidae, Miller and Gidley, 1918. O total de peças neste grupo também não vai muito além de $1 \%$ (Figura 2.2).

Na Tabela 2.1 é possível visualizar ainda um total de, no mínimo, 41 indivíduos pertencentes a cinco grupos taxonômicos contabilizados a partir de 6140 peças, entre ossos, dentes e fragmentos de ambos. Entre eles é possível verificar que apenas 1 indivíduo, de Panthera onca, pertence à megafauna (> $44 \mathrm{~kg}$ ) e os 40 indivíduos restantes são de porte médio ( $>5$ e $<44 \mathrm{~kg}$ ). Verificase também que apenas 1 é carnívoro (Panthera onca), sendo que 16 são onívoros (Tayassuidae) e 24 são herbívoros (Cervidae, Cuniculus sp. e Cuniculus paca). Para Cuniculus sp. assumiu-se o mesmo tipo de dieta de Cuniculus paca, em decorrência da total conformidade osteológica e dentária entre as espécies.

Na Figura 2.3 é possível observar a distribuição conjunta dos ossos de meso e megamamíferos exumados do Locus 3 da Gruta Cuvieri, considerando tanto os animais identificados no presente trabalho, quanto aqueles identificados por Hubbe (2008). Na vista de planta verifica-se que tanto os restos de mamíferos de médio porte, quanto os de megafauna, distribuem-se amplamente pelas áreas escavadas no Locus $3 \mathrm{~A}$ e B. Já na vista leste (Figura 2.3) é possível constatar que os restos de megafauna estão distribuídos quase 

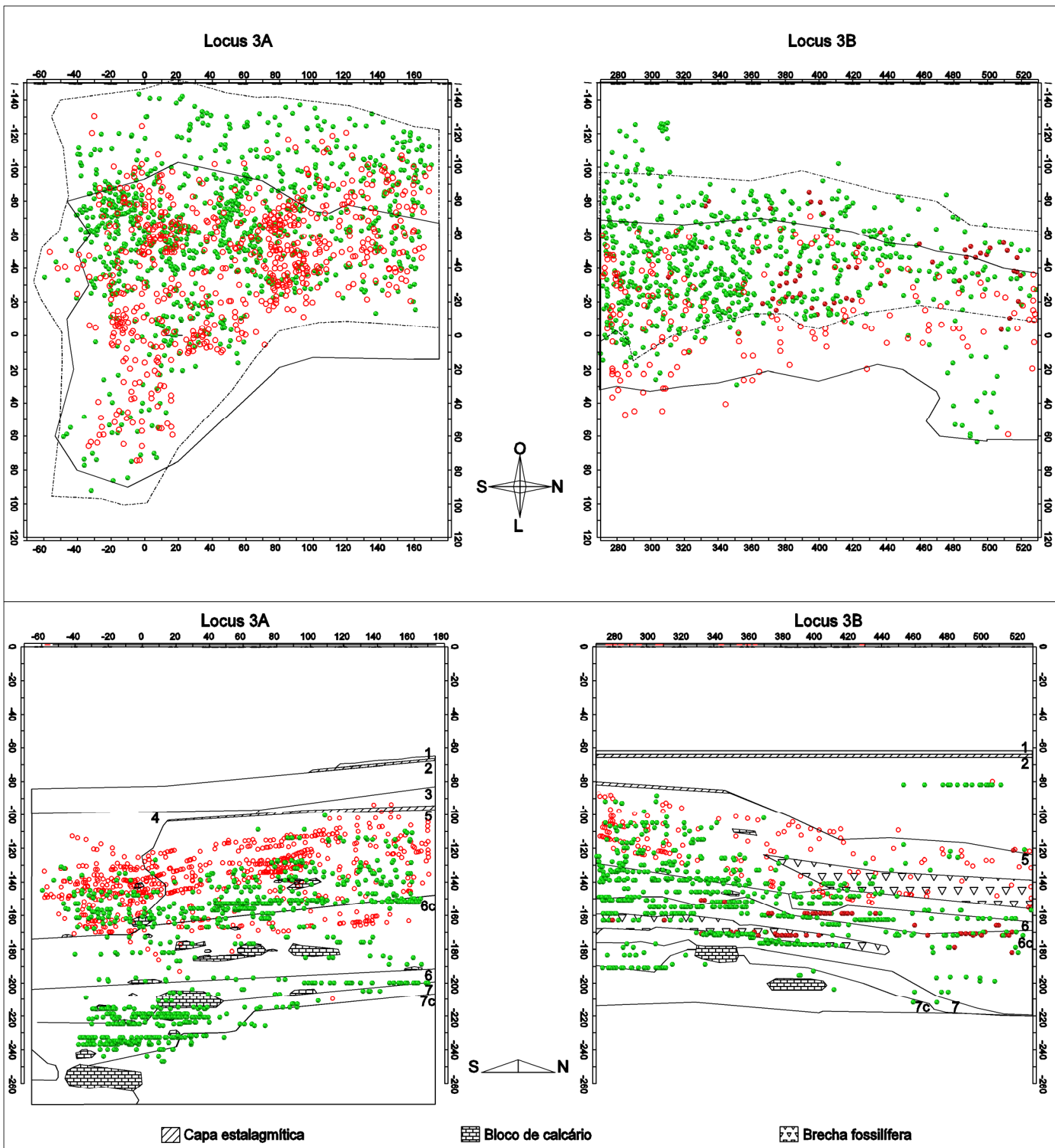

Figura 2.3 - Distribuição dos ossos de mamíferos de médio e grande porte exumados do Locus 3 da Gruta Cuvieri. Acima vista de planta, abaixo vista leste. Cada símbolo representa um espécime, sendo que os mesomamíferos estão representados pela cor verde e a megafauna pela cor vermelha. As esferas referem-se aos fósseis analisados neste trabalho e os círculos aos estudados por Hubbe (2008). Na vista de planta o contorno superior das paredes do locus está representado em linha contínua e o inferior em tracejada. As fácies estão identificadas por números do lado direito de cada subdivisão do Locus 3. 
que exclusivamente na metade superior do pacote fossilífero, ocorrendo em meio às facies 4,5 e 6 consolidada em ambas as subdivisões do locus. Por outro lado, os restos de mesomamíferos distribuem-se por todas as fácies fossilíferas, desde a 2 até a 7 consolidada, excetuando-se a fácies 3.

Abaixo segue a Tabela 2.2 onde constam os principais resultados obtidos com as análises realizadas nesta seção do capítulo.

Tabela 2.2 - Principais resultados obtidos com as análises realizadas nesta seção do capítulo.

\begin{tabular}{cl}
\hline \multicolumn{1}{c}{ Análise } & \multicolumn{1}{c}{ Resultados } \\
\hline $\begin{array}{c}\text { Identificação } \\
\text { taxonômica }\end{array}$ & $\begin{array}{l}\text { Presença dos taxons Tayassuidae, Cervidae, Cuniculus } \\
\text { paca, Cuniculus sp. e Panthera onca. }\end{array}$ \\
\hline $\begin{array}{c}\text { Número mínimo } \\
\text { de indivíduos }\end{array}$ & $\begin{array}{l}\text { Presença de animais de médio e grande porte. } \\
\text { Prescha de 16 indivíduos de Tayassuidae, } 8 \text { de Cervidae, } \\
\text { Panthera onca. }\end{array}$ \\
\hline $\begin{array}{c}\text { Distribuição dos } \\
\text { restos de meso e } \\
\text { megamamíferos }\end{array}$ & $\begin{array}{l}\text { Megafauna restringe-se principalmente à metade superior } \\
\text { do pacote fossilífero e os mesomamíferos ocorrem nele } \\
\text { todo. }\end{array}$ \\
\hline
\end{tabular}




\section{Discussão}

De maneira geral, a identificação anatômica e taxonômica foi dificultada pelo alto grau de fragmentação das peças, que se reflete, ainda que não completamente, no grande percentual de peças não identificadas taxonomicamente $(42 \%)$. Em outros casos, as concreções carbonáticas obliteravam regiões anatômicas importantes para o diagnóstico taxonômico. Esta dificuldade foi minimizada pelos tratamentos mecânico e químico, realizados durante a cura. Outra adversidade decorreu das semelhanças morfológicas apresentadas por alguns elementos ósseos dos integrantes da ordem Artiodactyla (Tayassuidae e Cervidae) e do gênero Cuniculus, os quais representam juntos, pouco mais de $50 \%$ da amostra estudada.

Considerando que Mayer (2007) e Hubbe (2008) elencaram diversos argumentos a favor de que a queda de animais em abismos foi o principal processo de incorporação óssea ao Locus 3, discute-se a seguir alguns aspectos da ecologia dos animais identificados e que são compatíveis com esta forma de acumulação óssea. Assim, a composição taxonômica observada no Locus 3 pode ser explicada baseando-se na observação de Simms (1994), de que diferentes animais se valem de cavernas para inúmeros fins, aliada às características geomorfológicas apresentadas pela Gruta Cuvieri (Figura 1.2). Como mencionado anteriormente, a gruta apresentava duas entradas das quais, atualmente, a maior delas está colapsada. No entanto, os esqueletos de megafauna exumados previamente nos Loci 1 (Catonyx cuvieri), 2 (Smilodon populator, Lund, 1842, Tapirus terrestris e Valgipes bucklandii, Cartelle et al., 2009) e 3 (Catonyx cuvieri, Tapirus terrestris e Valgipes bucklandii), sugerem que provavelmente esta antiga entrada constituía ampla passagem pelo menos 
até próximo da transição Pleistoceno/Holoceno.

Apesar de o conduto principal da caverna apresentar alguns blocos abatidos, não há nenhum acidente topográfico que bloqueie efetivamente a passagem. Além do que, uma considerável luminosidade penetra o conduto principal durante alguns períodos do dia. Assim, como o acesso ao conduto principal e aos subseqüentes fossos é relativamente fácil, animais com anatomias relativamente diferenciadas (por exemplo, Tayassuidae - corpo robusto com membros fortes e curtos - e Cervidae - corpo esguio com membros frágeis e longos) puderam entrar na caverna, contribuindo potencialmente para a variedade de táxons nela encontrada. É importante ressaltar que além dos animais identificados aqui e da megafauna estudada por Hubbe (2008), exumou-se também do Locus 3 grande quantidade de restos de pequenos mamíferos (Sylvilagus brasiliensis, Linnaeus, 1758; Dasyprocta sp., Illiger, 1811; Dide/phis sp., Linnaeus, 1758; Euphractus sexcinctus, Linnaeus, 1758; Canidae, Fischer, 1817; Felidae, Fischer de Waldheim, 1817 e pequenos roedores) e ainda de aves e anfíbios (Mayer, 2007).

De maneira geral, um traço comum a todos os grupos aqui identificados é que eles apresentam hábitos semi-fossoriais ou crepusculares/noturnos. Por exemplo, indivíduos viventes do gênero Cuniculus apresentam hábitos noturnos e tanto escavam as próprias tocas, como se valem das construídas por outros animais (Eisenberg e Redford, 1999). Estes mesmos animais, em regiões cársticas da Península de Yucatán, México, freqüentemente habitam estas cavidades naturais entre as rochas ao invés de escavar tocas (Nowak, 1999). Algumas espécies da família Cervidae, e todas da Tayassuidae, têm hábitos crepusculares/noturnos, ficando ativas algumas horas durante a noite, mesmo 
que somente em determinadas épocas do ano (Eisenberg e Redford, 1999). único carnívoro encontrado, Panthera onca, também apresenta hábitos noturnos (Eisenberg e Redford, 1999).

Tais situações expõem esses animais a ambientes com pouca ou nenhuma incidência luminosa, contribuindo para que eles eventualmente se aventurem no interior de cavernas, se acidentando ou se extraviando nestes locais. Esta idéia é reforçada pela observação de Simms (1994) de que diversos animais freqüentemente adentram cavernas para proteger-se de condições adversas, como baixas temperaturas e chuva. No caso de ecossistemas muito quentes, os animais são atraídos pela temperatura e pela umidade relativamente constantes encontradas no interior destas formações. Além disso, muitos mamíferos usam cavernas para dormir e procriar (Simms, 1994).

Outra linha de evidencia que pode motivar a entrada de animais em cavernas se relaciona a sua dieta. Segundo Barlow (2000) e Brightsmith (2002), vários mamíferos herbívoros e onívoros ingerem substratos minerais com a finalidade de proteger suas mucosas estomacais contra as toxinas dos vegetais que compõem sua dieta, um hábito denominado geofagia.

Barlow (2000) menciona que cavernas representam um dos tipos de ambientes mais visitados por mamíferos em todo o mundo para fins geofágicos. Sobre esta questão Czaplewski et al. (2002) argumenta que em áreas predominantemente calcárias a disponibilidade de substratos minerais em outros ambientes (como depósitos aluviais) deva ser escassa e as cavernas representem as fontes mais conspícuas destes recursos. Se considerarmos estas informações e ainda o fato de que cavernas contêm os depósitos com a 
maior variedade de sedimentos dos ambientes terrestres (Ford e Williams, 1994; Gillieson, 1996), é razoável aceitar que alguns animais adentrem estes ambientes na busca de recursos minerais e acabem ali se acidentando.

Com relação aos resultados do índice $\mathrm{MNI}$ é possível observar um contraste entre a abundância dos mesomamíferos $(>5$ e $<44 \mathrm{Kg}$; que somam 40 indivíduos) e dos megamamíferos (< $44 \mathrm{Kg}$; que totalizam 8 indivíduos) identificados majoritariamente por Hubbe (2008). Em seu trabalho, Hubbe (2008) diagnosticou para o Locus 3, no mínimo, 3 indivíduos de Tapirus terrestris (160-317 kg; Nunes et al., 2001), 3 de Catonyx cuvieri (>100 Kg; Toledo [1998]; Cartelle et al. [2009]) e 1 de Valgipes buckilandii (> $100 \mathrm{Kg}$; Toledo [1998]; Cartelle et al. [2009]).

Além deste, constata-se outro contraste entre o número mínimo de indivíduos de animais de diferentes níveis tróficos: carnívoros, 1 indivíduo; onívoros, 16 indivíduos; e herbívoros, 24 indivíduos.

O primeiro contraste pode ser explicado pelo padrão geral verificado por Damuth (1981) para mamíferos terrestres. Em seu trabalho o autor constatou que a densidade populacional destes animais em diversos habitats do planeta é inversamente relacionada com a massa corporal dos mesmos (Damuth, 1981). Segundo este padrão, maiores densidades populacionais de mesomamíferos, em relação aos megamamíferos, Ihes confere maior probabilidade de representação no registro fóssil, justificando os maiores números de indivíduos dos primeiros encontrados no Locus 3.

É importante ressaltar que o registro do Locus 3 não reflete este padrão de maneira perfeita. Isso porque embora os cervídeos aqui identificados tenham uma massa corporal próxima a dos taiassuideos (Tabela 2.1), os 
primeiros estão representados por 8 indivíduos, enquanto os últimos somam pelo menos 16 indivíduos. Essa diferença pode resultar principalmente de três motivos: 1) os tayassuideos apresentam comportamento gregário (Margarido e Mangini, 2001), enquanto que os cervídeos são predominantemente solitários (Wemmer, 1998); 2) o material do Locus 3 representa restos de mais de uma espécie da família Tayassuidae e 3) estas diferenças decorrem de diferenças no tamanho das populações de Tayassuidae e Cervidae.

Considerando o primeiro motivo, existe a possibilidade de que ao se aventurarem em grupo no interior da Gruta Cuvieri, mais de um indivíduo de Tayassuidae tenham se acidentado no Locus 3 numa mesma ocasião. Já os cervídeos, como o fizeram solitariamente, são representados por menor número de indivíduos.

De acordo com o segundo motivo, tanto indivíduos da espécie Tayassu pecari, Link, 1795 quanto da Pecari tajacu, Linnaeus, 1758 estão representados entre o material do Locus 3 , resultando no grande número de animais atribuídos à família Tayassuidae. A diferenciação dos restos de cada espécie não foi realizada para o material do Locus 3 principalmente devido a três dificuldades: os fósseis apresentam-se bastante fragmentados (como discutido no Capítulo 3.Tafonomia); a morfologia óssea de ambas as espécies é muito semelhante; e existe sobreposição de tamanho entre elas (Eisenberg e Redford, 1999). Assim, o diagnóstico específico destes animais requer trabalhos futuros que avaliem detalhadamente cada um destes aspectos.

Quanto às diferenças populacionais, é possível que durante a formação do pacote fossilífero do Locus 3 os Tayassuidae apresentassem tamanhos 
populacionais maiores do que os dos Cervidae, e isso tenha se refletido no registro fóssil.

Baseado nas informações disponíveis atualmente não é possível optar entre os motivos da maior representação de indivíduos da família Tayassuidae, mas como eles não são mutuamente exclusivos, é possível que os três motivos apresentados tenham contribuído para o estabelecimento do padrão observado.

Com relação ao segundo contraste observado, entre carnívoros, onívoros e herbívoros, ele também reflete em linhas gerais um padrão observado em comunidades atuais. Segundo Cohen et al. (2003), a densidade populacional de animais tende a diminuir nos níveis tróficos mais elevados. Isto faz com que carnívoros de topo, como a onça identificada no Locus 3, tenham menores probabilidades de serem preservados no registro fóssil, o que explica o baixíssimo número de indivíduos com hábitos carnívoros verificado no abismo.

Este padrão é verificado também em outros depósitos fossilíferos cuja principal via de acumulação óssea é a queda em abismos (White et al., 1984; Brown e Wells, 2000; Ostbye et al., 2006; Reed, 2006). Assim, a proporção entre carnívoros, onívoros e herbívoros identificada no Locus 3 pode ser considerada esperada, pois é condizente com a estrutura geral observada nas comunidades naturais atuais.

Considero importante enfatizar que os dois contrastes discutidos, apesar de refletirem de maneira aproximada os padrões esperados, representam as comunidades pretéritas através de um panorama incompleto e, em certo grau, enviesado. Isso se deve principalmente ao fato de que o Locus 3 
provavelmente aprisionou animais durante uma considerável faixa temporal, resultando na mistura de animais que viveram em diferentes momentos ao longo do tempo. Como mencionado, a cronologia deste abismo é problemática e, atualmente, não permite estimar o período durante o qual isso ocorreu. Conseqüentemente, tanto os grupos taxonômicos ali representados, quanto suas respectivas abundâncias, potencialmente derivam de momentos diferentes ao longo de uma seqüência de flutuações populacionais experimentadas pelas comunidades que habitaram a região no passado.

Outro aspecto importante relativo à fauna recuperada no Locus 3 referese ao potencial de aprisionamento de animais deste abismo. De acordo com Kos (2003b), Haynes (1980) e Wang e Martin (1993) existem três parâmetros principais que provêm informações sobre o potencial de incorporação faunística de depósitos fossilíferos em abismos: 1) variedade faunística; 2) o peso corporal dos animais e 3) estado de desenvolvimento dos animais. De acordo com os autores (Kos, 2003; Haynes, 1980; Wang e Martin, 1993), uma grande variedade faunística, com a presença de animais que apresentam marcadas diferenças em termos de peso corporal e faixa etária são indicativas de pouca seleção no processo de queda/aprisionamento acidental dos animais.

Sob esta perspectiva, o Locus 3 parece apresentar um potencial moderado para a incorporação de animais. Primeiramente, por que mesmo aliando os resultados do presente trabalho aos de Mayer (2007) e Hubbe (2008), até o momento a fauna dali exumada não é muito variada. Se considerarmos que os animais identificados em níveis taxonômicos supragenéricos (Tayassuidae, Cervidae, Canidae, Felidae, pequenos roedores, aves e anfíbios) representam ao menos um gênero cada, a somatória com os 
demais animais identificados (Tapirus terrestris, Panthera onca, Valgipes bucklandii, Catonyx cuvieri, Cuniculus paca, Cuniculus sp., Dasyprocta sp., Euphractus sexcinctus, Sylvilagus brasiliensis e Didelphis sp.) totaliza 16 gêneros. Assim, mediante a mais expressiva coleção de mamíferos do Quaternário brasileiro, que foi reunida por Lund em Lagoa Santa (Kipnis, 1998) e totaliza 100 gêneros (Cartelle, 1994), aqueles identificados no Locus 3 representam apenas uma pequena variedade taxonômica, indicando considerável intensidade na seleção dos animais aprisionados no abismo.

No que tange a variação no peso corporal dos animais do Locus 3 , o potencial de aprisionamento de animais mostra-se bastante inclusivo, porém, não completamente. Levando em conta os animais identificados aqui, mais aqueles em Mayer (2007) e em Hubbe (2008), estão representados no Locus 3 mamíferos pequenos ( $<5 \mathrm{~kg} ; 32$ indivíduos), médios ( $>5$ e $<44 \mathrm{~kg} ; 40$ indivíduos) e grandes (> 44 kg; 8 indivíduos), sugerindo a ausência de seleção de tamanho sobre os animais aprisionados no abismo. Sabe-se que alguns representantes da megafauna pleistocênica de Minas Gerais (e.g. Toxodon platensis) apresentavam massas corporais superiores a dos megamamíferos exumados do Locus 3 (Tapirus terrestris, Valgypes bucklandii e Catonyx cuvieri). No entanto, segundo Hubbe (comunicação pessoal, 2011), restos ósseos de animais com tamanho extraordinariamente grande não são encontrados freqüentemente em Lagoa Santa. Portanto, como a amplitude de variação no peso corporal dos animais exumados do Locus 3 abrange boa parte de toda a gama existente na região no final do Pleistoceno, a seleção para tamanho dos animais aprisionados no abismo deve ter sido branda.

Com relação à estrutura etária dos táxons identificados no Locus 3 , 
estão disponíveis apenas dados sobre a megafauna (Hubbe, 2008), limitando considerações a este respeito. Pesquisas futuras que considerem a questão para os pequenos e médios mamíferos poderão fornecer esclarecimentos sobre esta questão.

Como um dos aspectos discutidos (baixa variedade taxonômica) indica uma seleção forte e o outro (considerável amplitude de peso corporal) uma seleção amena, considera-se que, de maneira geral, o potencial de aprisionamento do Locus 3 possa ser classificado como complexo.

A este panorama soma-se o fato de que os representantes da megafauna ocorriam quase que exclusivamente na metade superior do pacote fossilífero (Figura 2.3), indicando que o potencial de incorporação de organismos ao Locus 3 tenha mudado ao longo do tempo.

Com base nas datações disponíveis para a megafauna de Lagoa Santa é possível descartar o argumento de que estes animais não estavam presentes nas fácies inferiores do Locus 3 por não ocorrerem na região anteriormente (e.g. Catonyx cuvieri, com idade mínima de 123.934ะ1635 anos; Auler, 2006) e em tempos próximos (e.g. Catonyx cuvieri, com idade mínima de 9990ะ 40 anos; Piló e Neves, 2003) aos da formação do depósito estudado (cujas datações por carbono são de aproximadamente 12.500 anos e por urânio/tório têm idade mínima de 29.000 anos). Desta forma, uma explicação para esta mudança na capacidade de aprisionamento de animais provavelmente está relacionada com a morfologia da Gruta Cuvieri e sua evolução em associação com a dolina à sua frente.

Segundo Auler (2009), o padrão geral de sedimentação nas cavernas de Lagoa Santa que são associadas à dolinas, como é o caso da Gruta Cuvieri, 
inclui a exposição gradativa da entrada destas formações. Mais especificamente, de acordo com Haddad-Martim (2007) que concebeu um modelo preliminar para a evolução sedimentar da Gruta Cuvieri, em determinado momento (estágio V; Haddad-Martim, 2007) ocorreu o esvaziamento dos condutos, possibilitando o ingresso dos primeiros animais na caverna. Posteriormente (estágio VI, Haddad-Martim, 2007), as aberturas da caverna se tornaram mais amplas e numerosas, permitindo a entrada de animais maiores do que ocorria anteriormente. Sob esta óptica, inicialmente, enquanto a entrada da caverna esteve apenas parcialmente desobstruída, o Locus 3 teria aprisionado somente mamíferos de pequeno e médio porte. Isto explica a ocorrência de restos ósseos de taiassuídeos, cuja presença em Lagoa Santa é atestada por idades anteriores (>250.000 anos; Auler, 2006) e posteriores ao término da formação do depósito do Locus $3(10.470+40$; Hubbe et al., 2009), em praticamente todas as fácies deste abismo. Mais tarde, com a ampliação da passagem decorrente do aprofundamento da dolina (HaddadMartim, 2007), tanto os animais de pequeno, quanto de médio e grande porte passaram a se acidentar no Locus 3, como foi verificado nas fácies superiores deste abismo. Após isso, com o declínio na diversidade e abundância da megafauna pleistocênica regional, que culminou na extinção destes animais, seus restos ósseos já não eram incorporados ao Locus 3, fato que ocorreu somente com alguns animais de médio porte. 


\subsection{0 registro fóssil do gênero Cuniculus}

\section{Introdução}

Entre os roedores de origem sul americana, as pacas (Rodentia, Cuniculidae) integram uma das famílias menos diversas, com apenas duas espécies viventes: Cuniculus paca, Linnaeus, 1766 e Cuniculus taczanowskii, Stolzmann, 1865 (Wilson e Reeder, 2005; Eisenberg e Redford, 1999; Pérez, 1992; Moojen, 1952). A distribuição geográfica dos representantes atuais da família Cuniculidae é bem conhecida e abrange uma ampla área Neotropical, incluindo o Brasil, o que revela a tolerância destes animais a uma grande variedade de habitats florestais (Eisenberg e Redford, 1999). Com relação ao registro fóssil brasileiro, a espécie vivente Cuniculus paca já foi encontrada em depósitos quaternários de parte considerável do país, incluindo os estados do Rio Grande do Sul, São Paulo, Minas Gerais, Goiás, Bahia, Piauí e Pará (Hadler, 2009). Por outro lado, não há registros de fósseis de Cuniculus taczanowskii até o momento (Paula Couto, 1979).

Além das linhagens viventes, Lund (1950) descreveu duas espécies extintas para a família Cuniculidae: Cuniculus laticeps, Lund, 1837 e Cuniculus major, Lund, 1837. Ao caracterizar os esqueletos destes animais, Lund enfatiza a grande semelhança morfológica entre seus ossos póscranianos e os da espécie vivente, Cuniculus paca. Lund (1950) relata que Cuniculus laticeps apresenta tamanho similar ao de Cuniculus paca, mas seu crânio é muito mais largo, com grande distanciamento entre os arcos zigomáticos e as maxilas, dando-Ihe um aspecto achatado no sentido dorso 
ventral. Já para Cuniculus major, Lund (1950) relata que a característica mais marcante é seu tamanho agigantado em relação à Cuniculus paca, praticamente igualando-se ao da capivara vivente (Hydrochaeris hidrochaeris). Cuniculus major também é considerada como uma espécie por Rusconi (1932) e Cartelle (1999; 2002); enquanto que nos trabalhos de Winge (1888) e de Paula Couto (1975) ambas as pacas extintas são mencionadas como subespécies de Cuniculus paca. Até o presente, todos os registros de ambas as espécies extintas ocorreram na região de Lagoa Santa, Minas Gerais, sendo que praticamente todos foram realizados por Lund. Com base nestes achados, Patterson e Pascual (1968) atribuíram a origem da família Cuniculidae ao Pleistoceno Terminal, o que posteriormente foi confirmado através de comparações entre datações de depósitos brasileiros e argentinos (Paula Couto, 1975; Cartelle, 1999).

Tanto as pacas extintas quanto as viventes apresentam extraordinária expansão lateral e dorso-ventral do osso jugal, resultando em arcos zigomáticos que formam verdadeiras câmaras ósseas recobertas externamente por rugosidades de aspecto irregular (Moojen, 1952; Hershkovitz, 1956; Eisenberg e Redford, 1999; Oliveira et al., 2006). Segundo Pérez (1992), este desenvolvimento zigomático é verificado apenas em outro roedor, Lophiomys sp., Milne-Edwards, 1867, mas sua origem está relacionada à expansão de outros ossos (Kingdon, 1988), não sendo portanto, uma estrutura homóloga. O osso frontal das pacas também tem textura característica, devido às numerosas granulações irregulares que o recobrem (Moojen, 1952; Hershkovitz, 1956; Eisenberg e Redford, 1999; Oliveira et al., 2006). 
Apesar dos achados de C. major e C. paca terem ocorrido há mais de 150 anos, à exceção de Lund (1950), Winge (1888) e Rusconi (1932), os estudos que mencionam estes animais contribuíram pouco para uma melhor compreensão sobre os mesmos (e.g. Pictet, 1844; Paula Couto, 1975; Cartelle, 1999; Cartelle, 2002). A fim de contribuir para ampliar o pouco conhecimento disponível sobre as pacas extintas realizou-se uma revisão dos dados disponíveis na literatura e a comparação de tamanho entre os ossos exumados do Locus 3 e os de uma espécie vivente do mesmo gênero. Considerando a ênfase dada por Lund (1950) ao tamanho avantajado dos restos de Cuniculus major em relação aos de Cuniculus paca, o objetivo da comparação de tamanho é subsidiar preliminarmente o diagnóstico específico dos restos de Cuniculus sp. exumados do Locus 3 e registrar as médias osteométricas deste material.

\section{Material e método}

Os exemplares de Cuniculus sp. analisados estão depositados na coleção do LEEH-USP, enquanto os da espécie vivente, Cuniculus paca, estão depositados no Museu Nacional do Rio de Janeiro. As medidas utilizadas na comparação foram tomadas utilizando-se um paquímetro digital (Mitutoyo) com precisão de $0.01 \mathrm{~mm}$ e baseando-se na proposta de Driesch (1976) para os seguintes ossos: hemimandíbulas, úmeros, rádios, fêmures, tíbias, escápulas, talus e calcâneos.

\section{Resultados}

Os restos de Cuniculus sp. incluem dentes, ossos cranianos e pós- 
cranianos, alguns deles mantidos articulados por concreções carbonáticas (Figura 2. 4, R a T). Grande parte dos remanescentes ósseos apresenta-se fragmentada em tamanhos variados e por vezes com superfícies arredondadas por abrasão. A presença de dentes pré-molares em erupção (indicados com setas na Figura 2.4, G a M) e de epífises não fusionadas em vários ossos longos (Figura 2.4, N a Q) indica que os restos fósseis de pelo menos três indivíduos pertencem a animais jovens.

Segundo o catálogo de P. W. Lund, disponível no Museu de História Natural da Universidade de Copenhague, Dinamarca, as pacas extintas foram registrada nas lapas: do Baú, do Bento, do Capão Seco, de Cerca Grande, de Cerca Grande II, de Escrivânia I, V e XI, da Pedra dos Índios I, de Periperi I, dos Porcos, dos Tatus, do Sumidouro e Vermelha, totalizando quatorze sítios da região de Lagoa Santa, Minas Gerais. Com o registro efetuado na Gruta Cuvieri, na mesma região, amplia-se para quinze o número de sítios em que uma espécie extinta de paca foi encontrada. A Figura 2.5 mostra a posição dos sítios cuja localização é conhecida.

Como pode ser visto na Figura 2.4 os restos de Cuniculus sp. apresentam vários caracteres anatômicos comuns à Cuniculus paca (Oliveira et al., 2006), sendo: extraordinárias proporções dos arcos zigomáticos com os jugais enormemente expandidos, formando ampla câmara óssea (Figura 2.4, E e F; ver também vista lateral direita abaixo dos respectivos espécimes); rugosidades irregulares na superfície exterior do arco zigomático (Figura 2.4, E; em F as feições estão aparentes apenas na porção inferior do espécime); granulações irregulares no osso frontal (Figura 2.4, A); órbitas laterais e incompletas situadas medianamente entre o 


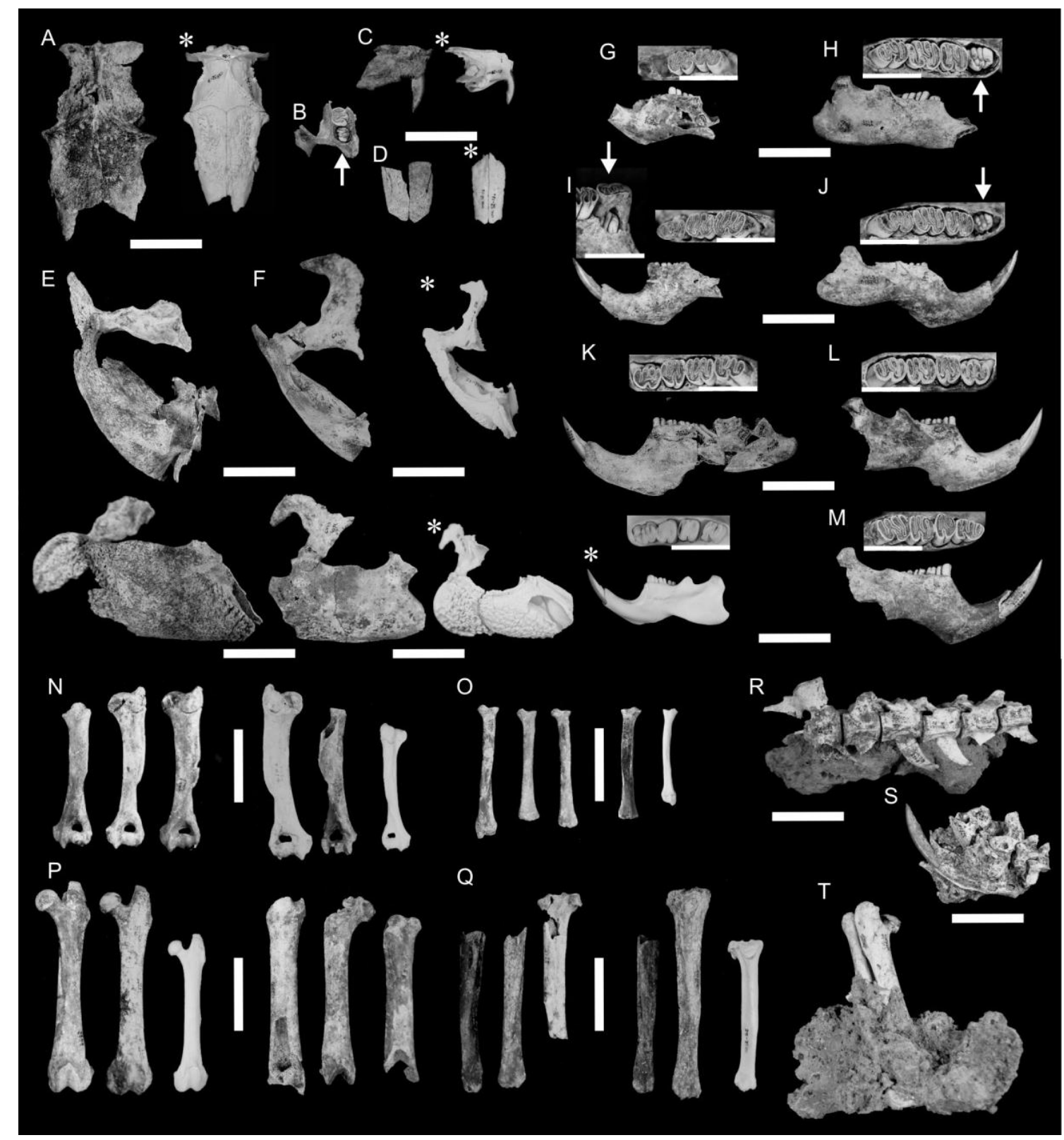

Figura 2.4 - Ossos cranianos e pós-cranianos de Cuniculus sp. e Cuniculus paca. Os ossos da espécie vivente estão indicados por *. A - vista dorsal da porção superior do crânio; B - vista ventral de fragmento de maxila esquerda; C - vista lateral de pré maxila direita; D - vista dorsal de nasais direito e esquerdo; $\mathrm{E}$ e $\mathrm{F}$ - vista dorsal de arco zigomático direito com respectivas vistas laterais direitas abaixo; G a M - vista lateral de hemimandíbulas direitas e esquerdas com respectivas ampliações dos dentes em vista oclusal acima de cada espécime; I - inclui ampliação em vista mesial exibindo o pré-molar decíduo e o respectivo dente permanente; $\mathrm{N}$ - úmeros direitos e esquerdos; $\mathrm{O}$ - rádios direitos e esquerdos; P - fêmures direitos e esquerdos; $Q$ - tíbias direitas e esquerdas; R - vista ventral de sacro e vértebras lombares articuladas preservadas em bloco de concreção; S - vista lateral esquerda de mandíbula direita e vértebras cervicais articuladas em bloco de concreção; T - vista lateral de fêmur e tíbia direitos articulados em bloco de concreção; Escalas nas ampliações $=2 \mathrm{~cm}$, no restante da figura $=5 \mathrm{~cm}$. 


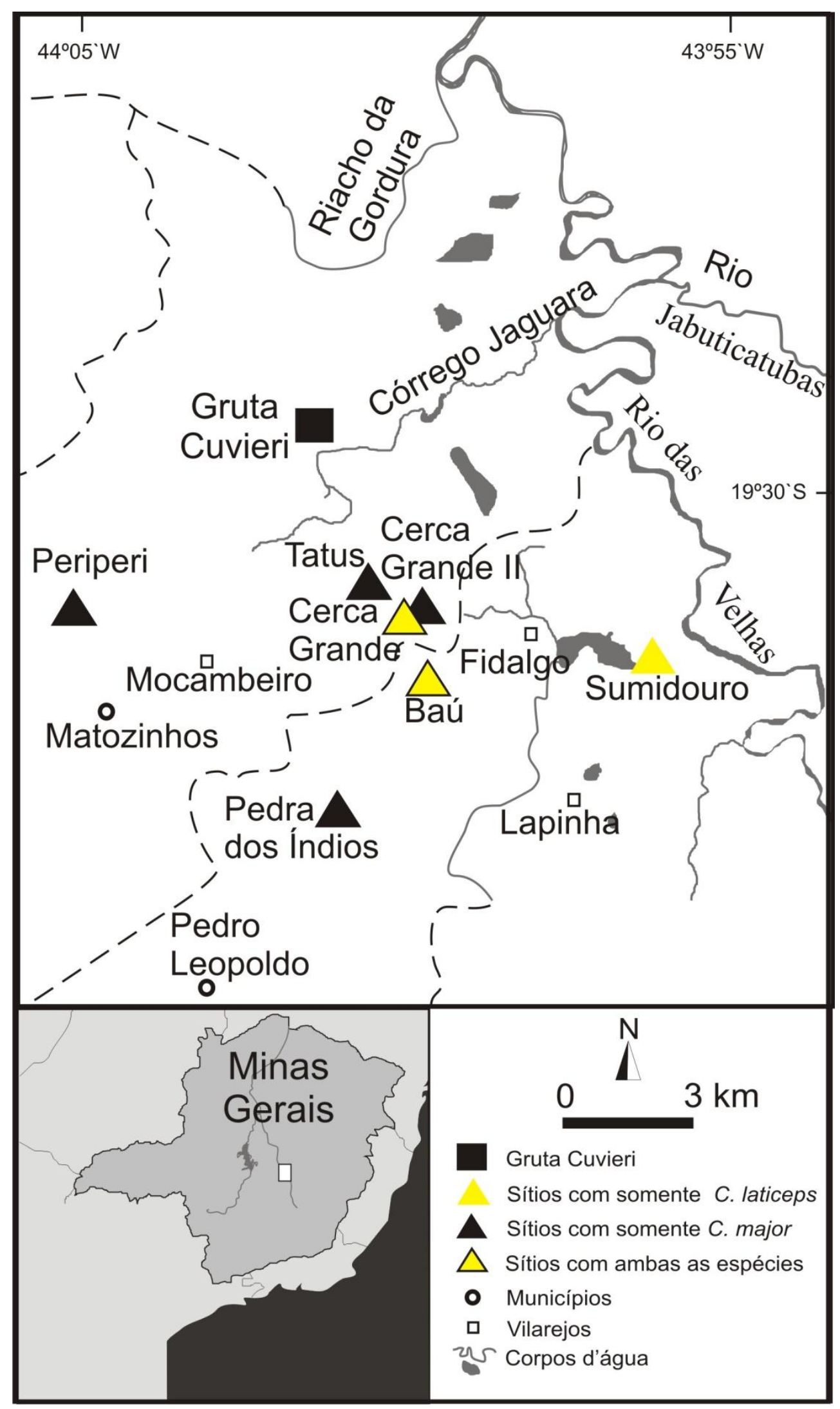

Figura 2.5- Mapa de parte da região de Lagoa Santa, Minas Gerais, mostrando os sítios para os quais Cuniculus laticeps e Cuniculus major foram reportadas e cuja localização é conhecida. 
occipital e o nasal (Figura 2.4, A); incisivos escalpriformes (Figura 2.4,G a M); esmalte dos pré-molares e molares disposto como folíolos internos adjacentes uns aos outros e aproximadamente paralelos no sentido vestíbulo-lingual (ver ampliações na Figura 2.4 G a M).

Considerando que nos roedores existe forte correlação de tamanho entre as fileiras dentárias inferiores e superiores (Moojen, 1952), verificou-se que a medida desta última no espécime tipo de Cuniculus major (fornecida por Winge, 1888; $40 \mathrm{~mm}$ ) é muito próxima da média obtida com a medida das hemimandíbulas de Cuniculus sp. recuperadas no Locus 3 (Tabela 2.3). O mesmo foi observado entre os diâmetros vestíbulo-lingual e ânteroposterior do terceiro molar superior medido por Rusconi (1932; respectivamente, 8 e $11.5 \mathrm{~mm}$ ) em relação à média daqueles do Locus 3 (Tabela 2.3).

Embora parte dos ossos de Cuniculus sp. do Locus 3 tenha pertencido a indivíduos jovens, a simples comparação visual demonstra que todos os restos ali encontrados são consideravelmente maiores que os de Cuniculus paca (Figura 2.4, A a Q).

Na Tabela 2.4 é possível observar as medidas das hemimandíbulas de Cuniculus sp. e Cuniculus paca, e suas respectivas médias e desvios padrão. Para todas as medidas efetuadas os valores da espécie extinta são maiores que os da vivente. A média da medida 2 apresenta o menor percentual de variação entre as espécies, sendo que a de Cuniculus sp. é $\sim 20 \%$ maior do que a de Cuniculus paca (Tabela 2.4). Se considerarmos as medidas 3, 5 e 5a, esta diferença é intermediária, com valores $\sim 25 \%$ maiores para Cuniculus sp. (Tabela 2.4). As maiores diferenças entre 
Tabela 2.3 - Médias e desvios padrão dos valores medidos a partir de fileiras dentárias e terceiros molares superiores de Cuniculus sp. do Locus 3 da Gruta Cuvieri e de Cuniculus major disponíveis na literatura. O tamanho das amostras está entre parênteses.

\begin{tabular}{|c|c|c|c|}
\hline $\begin{array}{c}\text { Parte } \\
\text { anatômica }\end{array}$ & Medida & $\begin{array}{c}\text { Média } \\
\text { Cuniculus sp. } \\
(\mathrm{mm})\end{array}$ & $\begin{array}{c}\text { Dados de } \\
\text { Cuniculus major } \\
(\mathrm{mm})\end{array}$ \\
\hline \multirow{6}{*}{$\begin{array}{c}\text { fileira } \\
\text { dentária } \\
\text { desvio padrão } \\
\text { terceiro molar } \\
\text { superior } \\
\text { desvio padrão } \\
\text { terceiro molar } \\
\text { superior } \\
\text { desvio padrão }\end{array}$} & \multirow{2}{*}{$\begin{array}{l}\text { comprimento } \\
\text { das coroas }\end{array}$} & 36.77 (3) & \multirow[t]{2}{*}{$40(1)^{*}$} \\
\hline & & 0,39 & \\
\hline & \multirow{2}{*}{$\begin{array}{c}\text { diâmetro } \\
\text { vestíbulo-lingual }\end{array}$} & $8.04(14)$ & \multirow[t]{2}{*}{$8(1)^{\star *}$} \\
\hline & & 0,58 & \\
\hline & \multirow{2}{*}{$\begin{array}{c}\text { diâmetro } \\
\text { ântero-posterior }\end{array}$} & $10.62(14)$ & $11.5(1)^{\star \star}$ \\
\hline & & 0,65 & \\
\hline
\end{tabular}

tamanho médio das mandíbulas dos animais comparados são exibidas pelas medidas 1 e 4, as quais são $30 \%$ maiores em Cuniculus sp. (Tabela 2.4).

Como pode ser observado na Tabela 2.5 todos os valores obtidos medindo-se os ossos longos de Cuniculus sp. também são superiores aos de Cuniculus paca. Os valores médios da maior largura proximal (Bp), distal (Bd), do maior comprimento (GL) e do maior comprimento a partir do côndilo (GLC) dos fêmures de Cuniculus sp. apresentam valores em média 20\% maiores do que os de Cuniculus paca (Tabela 2.5). As tíbias de Cuniculus sp. apresentam esta mesma diferença em relação a Cuniculus paca para a maior largura proximal (Bp) e distal (Bd) (Tabela 2.5). Diferenças percentuais de aproximadamente $25 \%$ entre as médias das espécies comparadas são verificadas para o maior comprimento (GL) das tíbias, dos rádios e dos úmeros, para a menor largura da diáfise (SD) de fêmures e de úmeros, para a maior largura proximal $(\mathrm{Bp})$ dos rádios e para a maior largura distal $(\mathrm{Bd})$ dos úmeros. (Tabela 2.5). As medidas de ossos longos que têm maior 
Tabela 2.4 - Medidas de hemimandíbulas de Cuniculus sp. e Cuniculus paca de acordo com Driesch (1976). 1, maior comprimento: Gonion caudale - Infradentale; 2, comprimento da fileira dentária, medido ao longo dos alvéolos; 3, comprimento do diastema, borda oral do alvéolo do terceiro prémolar - Infradentale; 5, altura do ramo vertical, Gonion ventrale - ponto mais alto do côndilo mandibular; 5 , altura do ramo vertical. D - direita, E - esquerda

\begin{tabular}{|c|c|c|c|c|c|c|c|c|}
\hline \multirow[t]{2}{*}{ Espécime } & \multirow[t]{2}{*}{ Lado } & \multirow[t]{2}{*}{ Taxon } & \multicolumn{6}{|c|}{ Medidas (mm) } \\
\hline & & & 1 & 2 & 3 & 4 & 5 & $5 a$ \\
\hline CVL3-P11221 & D & Cuniculus sp. & - & 38.26 & 79.84 & 42.40 & - & - \\
\hline CVL3-13149 & $D$ & Cuniculus sp. & - & 38.53 & 83.06 & 44.58 & 50.9 & - \\
\hline CVL3-13342 & $\mathrm{D}$ & Cuniculus sp. & 118.39 & - & 78.58 & - & 44.47 & 42.94 \\
\hline CVL3-4052 e 4080 & $\mathrm{D}$ & Cuniculus sp. & - & - & - & - & 51.06 & 49.04 \\
\hline CVL3-P13145* & $E$ & Cuniculus sp. & 140.34 & 38.44 & 83.01 & 45.30 & - & - \\
\hline Média & & & 129.37 & 38.41 & 81.12 & 44.09 & 48.81 & 45.99 \\
\hline desvio padrão & & & 15.52 & 0.14 & 2.27 & 1.51 & 3.76 & 4.31 \\
\hline MNRJ-26930 & $E$ & Cuniculus paca & 94.17 & 31.35 & 62.69 & 31.81 & 35.45 & 34.58 \\
\hline MNRJ-66167 & $D$ & Cuniculus paca & 97.95 & 30.99 & 61.6 & 31.31 & 41.93 & 36.12 \\
\hline MNRJ-66167 & $E$ & Cuniculus paca & 98.11 & 30.97 & 61.33 & 31.58 & 41.40 & 35.91 \\
\hline MNRJ-69148 & $E$ & Cuniculus paca & 91.52 & 27.15 & 58.62 & 32.60 & 34.55 & 34.15 \\
\hline MNRJ-69206 & D & Cuniculus paca & 86 & 30.52 & 57.53 & 28.05 & 33.96 & 31.59 \\
\hline MNRJ-69206 & $\mathrm{E}$ & Cuniculus paca & 86.06 & - & - & 28.02 & 33.70 & 31.73 \\
\hline MNRJ-69168 & $D$ & Cuniculus paca & - & 31.47 & 63.55 & 32.04 & 40.92 & . \\
\hline MNRJ-69168 & $E$ & Cuniculus paca & - & 32 & 63.41 & 31.60 & 40.79 & - \\
\hline MNRJ-74321 & $\mathrm{D}$ & Cuniculus paca & 93.51 & 31.7 & 61.08 & 30.18 & 38.68 & 36.14 \\
\hline MNRJ-20415 & $\mathrm{D}$ & Cuniculus paca & 87.51 & 30.34 & 60.49 & 30.52 & 35.89 & 35.01 \\
\hline MNRJ-20415 & $\mathrm{E}$ & Cuniculus paca & 87.97 & 30.48 & 59.71 & 31.27 & 36.05 & 34.97 \\
\hline MNRJ-20416 & $\mathrm{D}$ & Cuniculus paca & 99.99 & 31.21 & 63.35 & 34.31 & 39.32 & 37.94 \\
\hline MNRJ-20416 & $E$ & Cuniculus paca & 99.70 & 31.23 & 63.71 & 34.24 & 40.29 & 38.46 \\
\hline MNRJ-74324 & $D$ & Cuniculus paca & 91.35 & 34.13 & 61.97 & 28.08 & 34.74 & 33.24 \\
\hline MNRJ-74324 & $E$ & Cuniculus paca & 90.30 & 33.84 & 61.18 & 27.60 & 35.03 & 33.70 \\
\hline
\end{tabular}


Tabela 2.4- continuação

\begin{tabular}{|c|c|c|c|c|c|c|c|c|}
\hline \multirow[t]{2}{*}{ Espécime } & \multirow[t]{2}{*}{ Lado } & \multirow[t]{2}{*}{ Taxon } & \multicolumn{6}{|c|}{ Medidas (mm) } \\
\hline & & & 1 & 2 & 3 & 4 & 5 & $5 a$ \\
\hline MNRJ-4872 & $\mathrm{D}$ & Cuniculus paca & 102.35 & 32.66 & 62.97 & 30.62 & 37.74 & 36.08 \\
\hline MNRJ-4872 & $E$ & Cuniculus paca & 103.42 & 32.57 & 62.61 & 30.66 & 37.90 & 36.14 \\
\hline MNRJ-53664 & $\bar{D}$ & Cuniculus paca & 95.29 & 30.54 & 62.61 & 32.58 & 42.28 & 39.76 \\
\hline MNRJ-53664 & $E$ & Cuniculus paca & 95.70 & 30.88 & 62.16 & 32.53 & 42.87 & 40.36 \\
\hline MNRJ-28506 & $D$ & Cuniculus paca & 97.34 & 33.79 & 62.95 & 30.35 & 35.13 & 33.51 \\
\hline MNRJ-28506 & $E$ & Cuniculus paca & 97.76 & 33.85 & 63.11 & 30.16 & 34.99 & 33.34 \\
\hline MNRJ-1379 & $\mathrm{D}$ & Cuniculus paca & 94.89 & 26.32 & 58.91 & 32.66 & 34.10 & 31.67 \\
\hline MNRJ-1379 & $E$ & Cuniculus paca & 94.73 & 26.42 & 59.06 & 32.30 & 35.28 & 32.41 \\
\hline MNRJ-1378 & $\mathrm{D}$ & Cuniculus paca & 90.56 & 30.39 & 58.95 & 29.44 & 38.01 & 34.82 \\
\hline MNRJ-1378 & $E$ & Cuniculus paca & 92.23 & 29.92 & 59.42 & 31.04 & 37.86 & 35.42 \\
\hline MNRJ-1377 & $E$ & Cuniculus paca & 95.49 & 30.75 & 63.69 & 33.17 & 39.13 & 36.16 \\
\hline MNRJ-965 & $\bar{D}$ & Cuniculus paca & 88.57 & 28.80 & 54.96 & 28.19 & 34.84 & 33.47 \\
\hline MNRJ-965 & $E$ & Cuniculus paca & 88.26 & 29.39 & 56.05 & 27.73 & 35.26 & 34.54 \\
\hline MNRJ-8484 & D & Cuniculus paca & 83.85 & 30.77 & 57.29 & 27.35 & 31.54 & 30.66 \\
\hline MNRJ-8484 & $E$ & Cuniculus paca & 83.65 & 30.46 & 56.44 & 27.28 & 31.35 & 30.67 \\
\hline MNRJ-1682 & $\mathrm{D}$ & Cuniculus paca & 92.02 & 29.8 & 59.97 & 30.78 & 37.37 & 34.76 \\
\hline MNRJ-1682 & $\mathrm{E}$ & Cuniculus paca & 91.64 & 29.46 & 59.74 & 30.70 & 36.80 & 35.03 \\
\hline MNRJ-60557 & $D$ & Cuniculus paca & 84.08 & 28.29 & 52.85 & 26.08 & 35.43 & 32.89 \\
\hline MNRJ-60557 & $E$ & Cuniculus paca & 84.69 & 28.65 & 53.4 & 26.31 & 35.84 & 32.56 \\
\hline MNRJ-74326 & $D$ & Cuniculus paca & 95.42 & 30.68 & 61.82 & 31.44 & 37.90 & 36.32 \\
\hline MNRJ-74326 & $E$ & Cuniculus paca & 95.38 & 30.35 & 61.43 & 31.90 & 37.64 & 36.52 \\
\hline MNRJ-13516 & $\mathrm{D}$ & Cuniculus paca & 86.86 & 30.16 & 57.40 & 27.49 & 35.61 & 32.55 \\
\hline MNRJ-13516 & $E$ & Cuniculus paca & 86.08 & 30.15 & 57.35 & 27.24 & 34.61 & 31.57 \\
\hline MNRJ-6112 & $D$ & Cuniculus paca & 87.93 & 32.84 & 58.10 & 26.52 & 33.79 & 32.30 \\
\hline MNRJ-6112 & $\mathrm{E}$ & Cuniculus paca & 88.18 & 33.24 & 58.52 & 26.20 & 33.80 & 31.73 \\
\hline MNRJ-13515 & $\mathrm{D}$ & Cuniculus paca & 92.07 & 29.91 & 59.84 & 30.66 & 37.59 & 34.30 \\
\hline
\end{tabular}


Tabela 2.4- continuação

\begin{tabular}{ccccccccc}
\hline Espécime & Lado & Taxon & \multicolumn{7}{c}{ Medidas $\mathbf{( m m})$} \\
& & & $\mathbf{1}$ & $\mathbf{2}$ & $\mathbf{3}$ & $\mathbf{4}$ & $\mathbf{5}$ & $\mathbf{5 a}$ \\
\hline MNRJ-13515 & $\mathrm{E}$ & Cuniculus paca & 92.01 & 30.32 & 59.12 & 29.91 & 37.85 & 33.99 \\
MNRJ-8476 & $\mathrm{D}$ & Cuniculus paca & 90.37 & 32.37 & 59.15 & 28.43 & 35.89 & 34.68 \\
MNRJ-8476 & $\mathrm{E}$ & Cuniculus paca & 90.69 & 31.91 & 59.27 & 27.55 & 35.66 & 34.89 \\
MNRJ-8461 & $\mathrm{D}$ & Cuniculus paca & 94.05 & 31.54 & 60.57 & 29.13 & 38.12 & 34.46 \\
MNRJ-8461 & $\mathrm{E}$ & Cuniculus paca & 94.05 & 31.91 & 60.47 & 29.37 & 37.78 & 34.35 \\
MNRJ-8458 & $\mathrm{D}$ & Cuniculus paca & 95.90 & 29.91 & 61.38 & 31.94 & 38.24 & 34.74 \\
MNRJ-8458 & $\mathrm{E}$ & Cuniculus paca & 95.70 & 29.68 & 60.76 & 32.21 & 38.08 & 34.18 \\
MNRJ-8283 & $\mathrm{D}$ & Cuniculus paca & 88.84 & 26.20 & 55.68 & 30.56 & 36.52 & 33.51 \\
MNRJ-8283 & $\mathrm{E}$ & Cuniculus paca & 88.80 & 26.55 & 56.65 & 30.11 & 35.81 & 33.69 \\
MNRJ-A238449 & $\mathrm{D}$ & Cuniculus paca & 94.03 & 29.40 & 59.63 & 30.25 & 35.02 & 32.11 \\
MNRJ-A238449 & $\mathrm{E}$ & Cuniculus paca & 94.19 & 28.99 & 59.08 & 30.73 & 34.99 & 32.05 \\
Média & & & $\mathbf{9 2 . 2 1}$ & $\mathbf{3 0 . 5 2}$ & $\mathbf{5 9 . 6 6}$ & $\mathbf{2 9 . 9 5}$ & $\mathbf{3 6 . 5 6}$ & $\mathbf{3 4 . 3 6}$ \\
desvio padrão & & & $\mathbf{4 . 8 0}$ & $\mathbf{1 . 9 1}$ & $\mathbf{2 . 6 6}$ & $\mathbf{2 . 1 4}$ & $\mathbf{2 . 5 8}$ & $\mathbf{2 . 1 2}$ \\
\hline
\end{tabular}

*Indica um espécime formado por vários pequenos fragmentos: CVL3-P13147, CVL3-P 13146, CVL3-P12935, CVL3-P13157, CVL3-P13158, CVL3-P13007 e CVL3-P13153. 
Tabela 2.5 - Medidas dos ossos longos de Cuniculus sp. e Cuniculus paca de acordo com Driesch (1976). Bplargura da região proximal; SD- menor largura de diáfise; GL-maior comprimento; Bd- maior largura da região distal; GLC-maior comprimento a partir do côndilo femoral. D - direito, E - esquerdo.

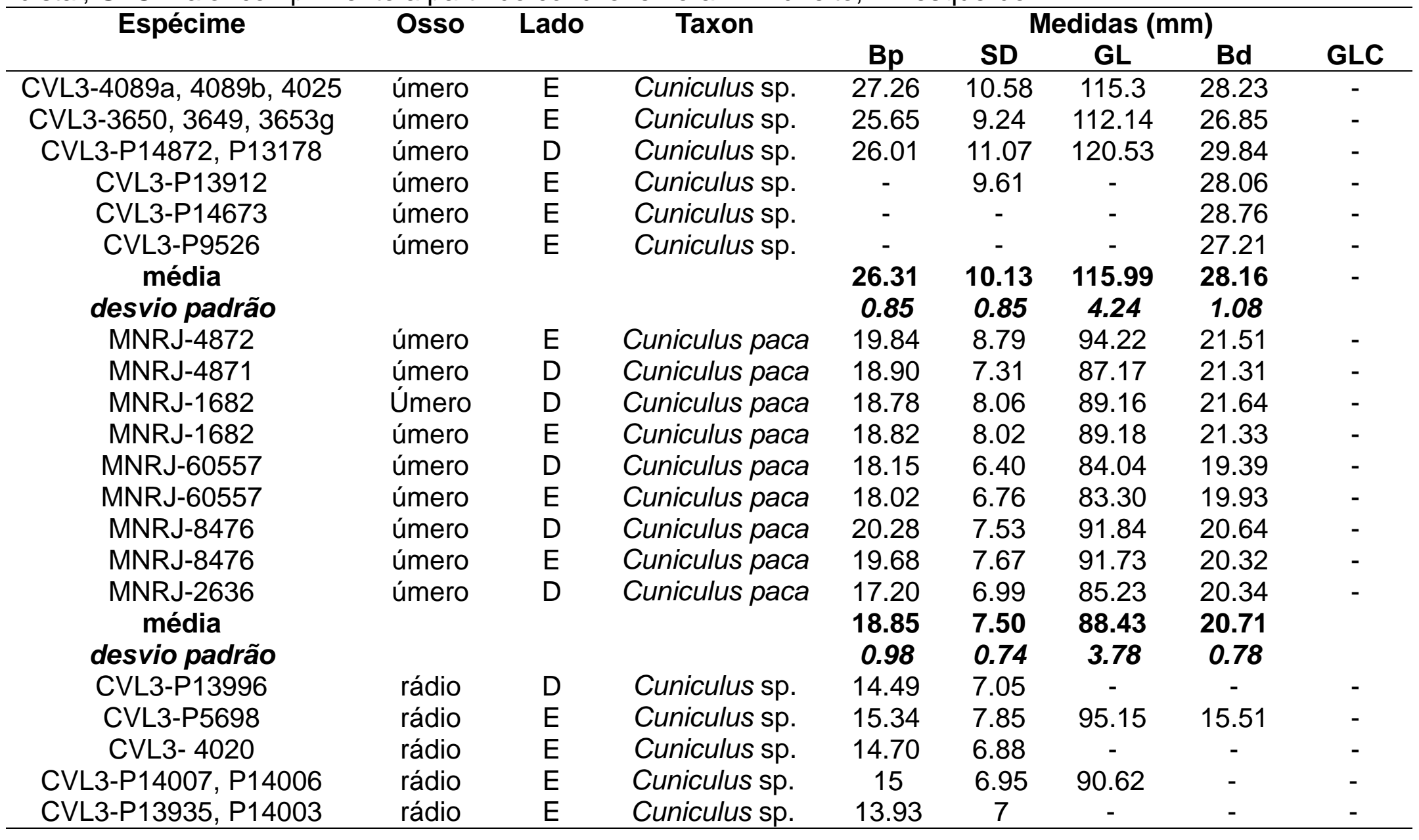


Tabela 2.5 - continuação

\begin{tabular}{|c|c|c|c|c|c|c|c|c|}
\hline \multirow[t]{2}{*}{ Espécime } & \multirow[t]{2}{*}{ Osso } & \multirow[t]{2}{*}{ Lado } & \multirow[t]{2}{*}{ Taxon } & \multicolumn{5}{|c|}{ Medidas (mm) } \\
\hline & & & & $\mathrm{Bp}$ & SD & GL & Bd & GLC \\
\hline CVL3-P5698 & rádio & $E$ & Cuniculus sp. & 13.78 & - & - & - & - \\
\hline CVL3-13996 & rádio & $\mathrm{D}$ & Cuniculus sp. & 13.47 & - & - & - & - \\
\hline CVL3-P9482 & rádio & $\mathrm{D}$ & Cuniculus sp. & 14.14 & - & - & - & - \\
\hline média & & & & 14.35 & 7.14 & 92.88 & 15.51 & \\
\hline desvio padrão & & & & 0.63 & 0.39 & 3.20 & - & \\
\hline MNRJ-4871 & rádio & $\mathrm{D}$ & Cuniculus paca & 10.83 & 4.82 & 68.04 & 10.70 & - \\
\hline MNRJ-1682 & rádio & $\mathrm{D}$ & Cuniculus paca & 10.75 & 5.12 & 71.25 & 10.99 & - \\
\hline MNRJ-1682 & rádio & $E$ & Cuniculus paca & 10.53 & 4.71 & 70.82 & 10.80 & - \\
\hline MNRJ-60557 & rádio & $\mathrm{D}$ & Cuniculus paca & 10.73 & 4.55 & 65.26 & 9.95 & - \\
\hline MNRJ-60557 & rádio & $E$ & Cuniculus paca & 10.75 & 4.77 & 65.80 & 9.90 & - \\
\hline média & & & & 10.72 & 4.79 & 68.23 & 10.47 & \\
\hline desvio padrão & & & & 0.11 & 0.21 & 2.77 & 0.51 & \\
\hline CVL3B-2170, 2171, 2172 & fêmur & $E$ & Cuniculus sp. & 35.81 & 15.03 & 137.37 & 31.64 & 129.65 \\
\hline CVL3B-2155a & fêmur & D & Cuniculus sp. & 35.81 & - & - & - & - \\
\hline CVL3-3520, 3432, 3437 & fêmur & $E$ & Cuniculus sp. & 35.64 & 15.16 & 137.86 & - & 131.45 \\
\hline CVL3-3523 & fêmur & $\bar{D}$ & Cuniculus sp. & - & 14.26 & - & - & - \\
\hline CVL3-P13091 & fêmur & $\mathrm{D}$ & Cuniculus sp. & - & 18.24 & - & - & - \\
\hline CVL3-P14011, P14013 & fêmur & $\mathrm{D}$ & Cuniculus sp. & - & 17.02 & - & - & - \\
\hline CVL3-P13917 & fêmur & $E$ & Cuniculus sp. & 37.99 & 17.40 & - & - & 144.29 \\
\hline CVL3-P13042 & fêmur & $E$ & Cuniculus sp. & - & 16.82 & - & - & - \\
\hline média & & & & 36.31 & 16.28 & 137.62 & 31.64 & 135.13 \\
\hline desvio padrão & & & & 1.12 & 1.46 & 0.35 & - & 7.98 \\
\hline MNRJ-4872 & fêmur & D & Cuniculus paca & 29.79 & 12.52 & 117.88 & 25.06 & 112.3 \\
\hline MNRJ-4871 & fêmur & D & Cuniculus paca & 29.72 & 12.17 & 109.08 & 25.18 & 104.08 \\
\hline MNRJ-1682 & fêmur & D & Cuniculus paca & 30.38 & 12.20 & 113.26 & 25.49 & 105.95 \\
\hline MNRJ-1682 & fêmur & $\mathrm{E}$ & Cuniculus paca & 30.20 & 12.47 & 113.92 & 25.55 & 105.27 \\
\hline
\end{tabular}


Tabela 2.5 - continuação

\begin{tabular}{|c|c|c|c|c|c|c|c|c|}
\hline \multirow[t]{2}{*}{ Espécime } & \multirow[t]{2}{*}{ Osso } & \multirow[t]{2}{*}{ Lado } & \multirow[t]{2}{*}{ Taxon } & \multicolumn{5}{|c|}{ Medidas (mm) } \\
\hline & & & & $\mathrm{Bp}$ & SD & GL & Bd & GLC \\
\hline MNRJ-60557 & fêmur & $\mathrm{D}$ & Cuniculus paca & 28.16 & 11.16 & 105.11 & 23.08 & 99.26 \\
\hline MNRJ-60557 & fêmur & $E$ & Cuniculus paca & 28.12 & 11.49 & 104.12 & 22.75 & 98.42 \\
\hline MNRJ-8476 & fêmur & $\mathrm{D}$ & Cuniculus paca & 29.89 & 12.41 & 114.69 & 25.49 & 106.90 \\
\hline MNRJ-8476 & fêmur & $\mathrm{E}$ & Cuniculus paca & 29.53 & 12.74 & 114.74 & 25.42 & 106.84 \\
\hline MNRJ-2636 & fêmur & $\mathrm{D}$ & Cuniculus paca & 28.37 & 12.02 & 105.67 & 25.29 & 101.29 \\
\hline média & & & & 29.35 & 12.13 & 110.94 & 24.81 & 104.48 \\
\hline desvio padrão & & & & 0.89 & 0.51 & 5.03 & 1.09 & 4.33 \\
\hline CVL3B-2155b & tíbia & D & Cuniculus sp. & - & - & - & 18.39 & - \\
\hline CVL3B-2173 & tíbia & $E$ & Cuniculus sp. & 32.05 & 11.14 & - & - & - \\
\hline CVL3-P13043 & tíbia & $\bar{E}$ & Cuniculus sp. & - & 12.11 & - & 19.49 & - \\
\hline CVL3-P13197 & tíbia & $\bar{D}$ & Cuniculus sp. & - & 12.15 & 142.68 & 19.47 & - \\
\hline média & & & & 32.05 & 11.80 & 142.68 & 19.12 & 32.05 \\
\hline desvio padrão & & & & - & 0.57 & - & 0.63 & - \\
\hline MNRJ-4872 & tíbia & $\mathrm{D}$ & Cuniculus paca & - & 8.53 & 107.81 & 14.85 & - \\
\hline MNRJ-4871 & tíbia & $\mathrm{D}$ & Cuniculus paca & 24.66 & 8.19 & 99.15 & 14.85 & - \\
\hline MNRJ-1682 & tíbia & $\mathrm{D}$ & Cuniculus paca & 25.21 & 8.13 & 104.79 & 14.70 & - \\
\hline MNRJ-1682 & tíbia & $E$ & Cuniculus paca & 25.24 & 8.37 & 104.78 & 14.94 & - \\
\hline MNRJ-60557 & tíbia & $\mathrm{D}$ & Cuniculus paca & 24.21 & 7.21 & 98.48 & 14.51 & - \\
\hline MNRJ-60557 & tíbia & $\mathrm{E}$ & Cuniculus paca & 23.69 & 7.17 & 98.62 & 14.90 & - \\
\hline MNRJ-8476 & tíbia & $\bar{E}$ & Cuniculus paca & 26.86 & 8.88 & 105.72 & 14.73 & - \\
\hline MNRJ-8476 & tíbia & $E$ & Cuniculus paca & 26.33 & 9.0 & 105.12 & 14.98 & - \\
\hline MNRJ-2636 & tíbia & $\mathrm{D}$ & Cuniculus paca & 23.97 & 9.02 & 99.65 & 14.67 & - \\
\hline média & & & & 25.02 & 8.28 & 102.68 & 14.79 & \\
\hline desvio padrão & & & & 1.12 & 0.70 & 3.64 & 0.15 & \\
\hline
\end{tabular}


percentual médio de variação são: a menor largura da diáfise (SD) das tíbias e dos rádios, a maior largura proximal $(\mathrm{Bp})$ dos úmeros e a maior largura distal (Bd) dos rádios, sendo os respectivos valores de Cuniculus sp. 30\% maiores do que os de Cuniculus paca (Tabela 2.5).

Entre os demais elementos pós-cranianos, as médias do menor comprimento do colo das escápulas (SLC) e do maior comprimento dos calcâneos (GL) de Cuniculus sp. são 20\% maiores que as de Cuniculus paca (Tabela 2.6). Já as médias do maior comprimento do processo glenóide (GLP) e da maior largura da cavidade glenóide (BG) das escápulas, bem como o maior comprimento (GL) dos calcâneos da primeira espécie são $\sim 25 \%$ maiores que as da última (Tabela 2.6). Finalmente, para o maior comprimento (GL) dos talus de Cuniculus sp. a diferença de médias em relação à Cuniculus paca é de 20\% (Tabela 2.6).

Na Tabela 2.7 constam os principais resultados obtidos com as análises realizadas nesta seção do capítulo. 
Tabela 2.6 - Medidas de escápulas, tálus e calcâneos de Cuniculus sp. e Cuniculus paca, segundo Driesch (1976). SLC-menor comprimento do colo da escápula; GLP-maior comprimento do processo glenóide; BG-largura da cavidade glenóide; G-maior comprimento; GB-maior largura. D-direita, E-esquerda.

\begin{tabular}{|c|c|c|c|c|c|c|c|c|}
\hline \multirow[t]{2}{*}{ Espécime } & \multirow[t]{2}{*}{ Osso } & \multirow[t]{2}{*}{ Lado } & \multirow[t]{2}{*}{ Taxon } & \multicolumn{5}{|c|}{ Medidas (mm) } \\
\hline & & & & SLC & GLP & BG & GL & GB \\
\hline CVL3-P13048 & escápula & $E$ & Cuniculus sp. & 15.06 & 21.84 & 15.55 & - & - \\
\hline CVL3-P9472 & escápula & $E$ & Cuniculus sp. & 14.18 & - & 14.75 & - & - \\
\hline CVL3-P13214 & escápula & D & Cuniculus sp. & 15.55 & - & - & - & - \\
\hline CVL3-P8225 & escápula & D & Cuniculus sp. & 14.18 & - & 13.12 & - & - \\
\hline CVL3-P1122 & escápula & D & Cuniculus sp. & 15.29 & - & - & - & - \\
\hline CVL3-3857 & escápula & D & Cuniculus sp. & 15.36 & - & - & - & - \\
\hline CVL3-3654 & escápula & D & Cuniculus sp. & 15.43 & - & - & - & - \\
\hline CVL3-4090 & escápula & $E$ & Cuniculus sp. & 15.61 & 21.37 & 14.67 & - & - \\
\hline média & & & & 15.08 & 21.61 & 14.52 & & \\
\hline desvio padrão & & & & 0.58 & 0.33 & 1.02 & & \\
\hline MN-4872 & escápula & $E$ & Cuniculus paca & 13.02 & 17.58 & 11.34 & - & - \\
\hline MN-4871 & escápula & D & Cuniculus paca & 12.84 & 16.65 & 11.10 & - & - \\
\hline MN-1682 & escápula & D & Cuniculus paca & 12.45 & 16.01 & 11.60 & - & - \\
\hline MN-1682 & escápula & $E$ & Cuniculus paca & 11.94 & 16.39 & 11.03 & - & - \\
\hline MN-60557 & escápula & $\bar{D}$ & Cuniculus paca & 11.16 & 15.29 & 10.83 & - & - \\
\hline MN-60557 & escápula & $E$ & Cuniculus paca & 11.11 & 15.31 & 10.43 & - & - \\
\hline MN-8476 & escápula & $\bar{D}$ & Cuniculus paca & 13.50 & 16.96 & 10.71 & - & - \\
\hline MN-8476 & escápula & $\mathrm{E}$ & Cuniculus paca & 13.49 & 16.99 & 10.84 & - & - \\
\hline média & & & & 12.44 & 16.40 & 10.99 & & \\
\hline desvio padrão & & & & 0.95 & 0.82 & 0.37 & & \\
\hline CVL3B-1625 & tálus & $E$ & Cuniculus sp. & - & - & - & 23.28 & - \\
\hline CVL3-P14066 & tálus & $\bar{D}$ & Cuniculus sp. & - & - & - & 23.24 & - \\
\hline CVL3-P14065 & tálus & D & Cuniculus sp. & - & - & - & 22.19 & - \\
\hline CVL3-P13969 & tálus & $E$ & Cuniculus sp. & - & - & - & 22.02 & - \\
\hline CVL3-P 13225 & tálus & $\bar{E}$ & Cuniculus sp. & - & - & - & 23.23 & - \\
\hline
\end{tabular}


Tabela 2.6 - continuação

\begin{tabular}{|c|c|c|c|c|c|c|c|c|}
\hline \multirow{2}{*}{ Espécime } & \multirow[t]{2}{*}{ Osso } & \multirow[t]{2}{*}{ Lado } & \multirow[t]{2}{*}{ Taxon } & \multicolumn{5}{|c|}{ Medidas (mm) } \\
\hline & & & & SLC & GLP & BG & GL & GB \\
\hline CVL3-P11191 & tálus & $\mathrm{E}$ & Cuniculus sp. & - & - & - & 23.06 & - \\
\hline CVL3-3664 & tálus & $E$ & Cuniculus sp. & - & - & - & 25.34 & - \\
\hline média & & & & & & & 23.19 & \\
\hline desvio padrão & & & & & & & 1.08 & \\
\hline MNRJ-4872 & tálus & $E$ & Cuniculus paca & - & - & - & 17.39 & - \\
\hline MNRJ-4871 & tálus & $\mathrm{D}$ & Cuniculus paca & - & - & - & 18.70 & - \\
\hline MNRJ-1682 & tálus & $E$ & Cuniculus paca & - & - & - & 18.77 & - \\
\hline MNRJ-1682 & tálus & $E$ & Cuniculus paca & - & - & - & 19.07 & - \\
\hline MNRJ-60557 & tálus & $\mathrm{D}$ & Cuniculus paca & - & - & - & 16.70 & - \\
\hline MNRJ-60557 & tálus & $\mathrm{E}$ & Cuniculus paca & - & - & - & 17 & - \\
\hline MNRJ-8476 & tálus & $\mathrm{D}$ & Cuniculus paca & - & - & - & 18.71 & - \\
\hline $\begin{array}{c}\text { MNRJ-8476 } \\
\text { média } \\
\text { desvio padrão }\end{array}$ & tálus & $E$ & Cuniculus paca & - & - & - & $\begin{array}{l}18.88 \\
18.15 \\
0.95\end{array}$ & - \\
\hline CVL3-P13182 & calcâneo & $\mathrm{D}$ & Cuniculus sp. & - & - & - & 47.65 & 18.76 \\
\hline CVL3-P13955 & calcâneo & $\mathrm{D}$ & Cuniculus sp. & - & - & - & - & 18.25 \\
\hline CVL3-P11182 & calcâneo & $\mathrm{D}$ & Cuniculus sp. & - & - & - & 44.61 & 19.44 \\
\hline CVL3-P13213 & calcâneo & $E$ & Cuniculus sp. & - & - & - & 47.46 & 18.90 \\
\hline CVL3-P13954 & calcâneo & $E$ & Cuniculus sp. & - & - & - & 42.64 & 18.64 \\
\hline CVL3B-2132 & calcâneo & $\mathrm{E}$ & Cuniculus sp. & - & - & - & 42.75 & 18.15 \\
\hline CVL3-4219 & calcâneo & $E$ & Cuniculus sp. & - & - & - & 47.01 & 19.32 \\
\hline CVL3-3586 & calcâneo & $E$ & Cuniculus sp. & - & - & - & - & 18.67 \\
\hline CVL3B-2132 & calcâneo & $\bar{E}$ & Cuniculus sp. & - & - & - & - & 18.15 \\
\hline CVL3-4219 & calcâneo & $E$ & Cuniculus sp. & - & - & - & 45 & 19.32 \\
\hline CVL3-3586 & calcâneo & $E$ & Cuniculus sp. & - & - & - & - & 18.67 \\
\hline média & & & & & & & 44.92 & 18.71 \\
\hline desvio padrão & & & & & & & 2.13 & 0.52 \\
\hline MNRJ-4871 & calcâneo & D & Cuniculus paca & - & - & - & 36.54 & 14.17 \\
\hline
\end{tabular}


Tabela 2.6 - continuação

\begin{tabular}{|c|c|c|c|c|c|c|c|c|}
\hline \multirow{2}{*}{ Espécime } & \multirow{2}{*}{ Osso } & \multirow{2}{*}{ Lado } & \multirow{2}{*}{ Taxon } & \multicolumn{5}{|c|}{ Medidas (mm) } \\
\hline & & & & SLC & GLP & BG & GL & GB \\
\hline MNRJ-1682 & calcâneo & $\mathrm{D}$ & Cuniculus paca & - & - & - & 36.75 & 14.31 \\
\hline MNRJ-1682 & calcâneo & $E$ & Cuniculus paca & - & - & - & 36.72 & 14.46 \\
\hline MNRJ-60557 & calcâneo & $\mathrm{D}$ & Cuniculus paca & - & - & - & 33.19 & 13.80 \\
\hline MNRJ-60557 & calcâneo & $E$ & Cuniculus paca & - & - & - & 33.10 & 13.80 \\
\hline $\begin{array}{l}\text { MNRJ-8476 } \\
\text { média } \\
\text { desvio padrão }\end{array}$ & calcâneo & $\mathrm{D}$ & Cuniculus paca & - & - & - & $\begin{array}{r}36.66 \\
35.66 \\
1.72\end{array}$ & $\begin{array}{l}14.40 \\
14.21 \\
0.31\end{array}$ \\
\hline
\end{tabular}

Tabela 2.7 - Principais resultados obtidos com as análises realizadas nesta seção do capítulo.

\begin{tabular}{ll}
\hline \multicolumn{1}{c}{ Análise } & \multicolumn{1}{c}{ Resultados } \\
\hline $\begin{array}{l}\text { Sítios com registro } \\
\text { de pacas extintas }\end{array}$ & $\begin{array}{l}\text { - } \\
\text { Gistribuição restrita à região de Lagoa Santa, Minas }\end{array}$ \\
\hline & $\begin{array}{l}\text { O material de Cuniculus sp. do Locus 3 tem medidas } \\
\text { compatíveis com as de Cuniculus major disponíveis } \\
\text { na literatura. }\end{array}$ \\
$\begin{array}{ll}\text { Comparação de } \\
\text { tamanho entre } \\
\text { Cuniculus sp.e }\end{array}$ & $\begin{array}{l}\text { Todas as medidas dos restos de Cuniculus sp. são } \\
\text { Cuniculus paca }\end{array}$ \\
& $\begin{array}{l}\text { maca. } \\
\text { Cuniculus do que as respectivas medidas de Cuniculus } \\
\text { que Cuniculus paca. }\end{array}$ \\
&
\end{tabular}




\section{Discussão}

As características anatômicas do material do Locus 3, incluindo: 1) as medidas compatíveis com as disponíveis para C. major na literatura; 2) as grandes proporções em relação à espécie vivente C. paca, aliada à 3) sua antiguidade e 4) a localização geográfica da descoberta representam fortes evidências que justificam a atribuição do material à Cuniculus major.

Com o novo registro efetuado, a Gruta Cuvieri representa atualmente o limite norte da distribuição geográfica de Cuniculus major entre os sítios de localização conhecida (Figura 2.5). A pequena distribuição dos restos deste grande roedor, até o momento, restrita à região de Lagoa Santa, Minas Gerais, contrasta com o registro fóssil de Cuniculus paca, encontrada em pelo menos sete estados brasileiros. Outro fato que chama a atenção é que apesar de outros estados brasileiros apresentarem depósitos pleistocênicos com abundantes restos de mamíferos fósseis (e.g. Bahia, Piauí e Rio Grande do Sul), as pacas extintas, Cuniculus major e Cuniculus laticeps, não foram registradas para estas localidades.

A carência de informações detalhadas sobre as pacas extintas representa uma grande dificuldade na identificação específica dos restos destes animais. Isso inviabiliza, conseqüentemente, a divulgação de novas descobertas de seus restos fósseis. O trabalho de Guérin (1991), por exemplo, parece refletir o pouco conhecimento disponível sobre as pacas extintas. O autor relata restos de Cuniculus paca e Cuniculus sp. provenientes de São Raimundo Nonato, Piauí. Uma vez que Guérin (1991) diferenciou Cuniculus sp. de Cuniculus paca, e quase que certamente a primeira não se refere a restos da espécie vivente Cuniculus tczanowskii 
(que ocorre em altitude, nos Andes; Eisenberg e Redford, 1999; Ríos-Uzeda, et al., 2004), parte do material reportado por este autor provavelmente pertence a uma das espécies extintas. No entanto, apesar dos esforços de Guérin (1991), esta informação não está disponível atualmente.

Com base nos dados disponíveis até o momento Cuniculus major representa o tronco da família Cuniculidae com menor distribuição geográfica que se tem notícia. Segundo esta distribuição, parece também que esta espécie apresentava menor tolerância a diferentes habitats do que as espécies viventes. Cuniculus paca, ocorre desde o norte do México (Moreno-Valdez et al., 1997) até o nordeste da Argentina, incluindo o leste do Paraguai, as Guianas e praticamente todo o Brasil (Wilson e Reeder, 2005; Eisenberg e Redford, 1999; Pérez, 1992). Segundo Eisenberg e Redford (1999), esta paca é relatada em diversos habitats florestais como manguezais, pântanos, matas ripárias e florestas de terra firme. Por sua vez, Cuniculus taczanowskii, habita os bosques nublados da cordilheira Andina da Venezuela, Colômbia, Equador, Peru e Bolívia (Eisenberg e Redford, 1999; Ríos-Uzeda, Wallace and Vargas, 2004), sendo freqüentemente encontrada entre 2.000-3.050 m de altitude (Ríos-Uzeda, Wallace and Vargas, 2004). Como visto, existe uma diferenciação clara entre os habitats ocupados por Cuniculus paca (terras baixas) e aqueles de Cuniculus taczanowskii, (bosques de altitude), mas Cuniculus paca e Cuniculus major são registradas apenas para terras baixas, o que pode indicar alguma semelhança entre os habitats por elas utilizados. Desta forma, é possível que durante a coexistência destas espécies a competição interespecífica entre elas promoveu, em alguma escala, a diferenciação no uso que cada 
espécie fazia do habitat (e.g. diferentes períodos de atividade entre as espécies; Begon, et al., 2007).

Com relação à abundância de Cuniculus major, Lund (1950) relata que nas cavernas por ele exploradas os seus restos eram bem menos numerosos que os de Cuniculus laticeps. Sabe-se que existem vários processos bióticos e abióticos que causam vieses de preservação de restos ósseos em cavernas, os quais, conseqüentemente, afetam as estimativas de abundância (e.g. Simms, 1994; Lyman, 1994a). Porém, se considerarmos o porte avantajado de Cuniculus major e a relação inversa entre massa corporal e densidade populacional de mamíferos, identificada por Damuth (1981), esta paca deve ter experimentado baixas densidades populacionais em relação a seus congêneres.

A baixa densidade populacional e a competição com Cuniculus paca podem ter sido importantes na extinção de Cuniculus major. Segundo o modelo proposto por Jonhson (2002) sobre as causas da extinção pleistocênica, as histórias de vida e a ecologia das espécies são fatores que influenciam diretamente as respectivas probabilidades de extinção. Uma das principais conclusões de Jonhson (2002) é a de que espécies com taxas reprodutivas baixas apresentavam maior probabilidade de extinção, sendo que aquelas que produziam menos de um filhote/fêmea/ano tinham $50 \%$ de chance de se extinguirem.

A história de vida de Cuniculus paca, e muito provavelmente a de Cuniculus major, são condizentes com a de um K-estrategista, com crescimento lento, intensa competição intra-específica, maturidade sexual tardia e baixa fecundidade, sendo a prole de tamanho grande e pouco 
numerosa (Begon, et al., 2007). Se considerarmos que ambas as espécies apresentam estas características de maneira relativamente análoga, Cuniculus major, que apresenta maior massa corporal, estaria sujeita a uma maturidade sexual ainda mais tardia do que a de Cuniculus paca. Assim, como Cuniculus paca já apresenta uma taxa reprodutiva de apenas um filhote por ano, com raras exceções (Eisenberg e Redford, 1999; Pachaly, 2001) - o que, segundo o modelo de Jonhson (2002), sugere grande probabilidade de extinção - Cuniculus major provavelmente excedia este limiar, e esta limitação reprodutiva pode ter sido determinante para a sua extinção.

Outro aspecto que deve ser considerado é que posteriormente à descrição de Cuniculus major, em 1837, alguns estudos revelaram uma tendência de diminuição da massa corporal de mamíferos desde o Último Máximo Glacial (UMG; Guthrie 1984; 2003; King e Saunders, 1984; Martin e Barnosky, 1993), entre 23.000 e 18.000 anos (Gasse, 2000; Clark e Mix, 2002). A partir deste cenário é possível que tanto os materiais atribuídos a Cuniculus major, quanto a Cuniculus paca pertençam à mesma linhagem, mas os primeiros representam a variedade mais comum em tempos pré UMG e os últimos aquela assumida pós UMG. Embora a comparação minuciosa de alguns caracteres anatômicos entre Cuniculus major e Cuniculus paca revele diferenças morfológicas (e.g. forma da borda superior do arco zigomático; Figura 2.4) que suportam o estatus específico de Cuniculus major, esta variação está contemplada na hipótese de que elas são uma mesma linhagem. Isso, por que, segundo os princípios da alometria, o aumento de tamanho de uma estrutura orgânica pode ter 
implicações sobre sua forma (Cheverud, 1982). O teste desta hipótese, no entanto, exige pesquisas futuras que investiguem se a trajetória alométrica que seria seguida por Cuniculus paca se este táxon experimentasse aumento de tamanho corporal coincide com as características observadas nos restos de Cuniculus major.

\section{Conclusão}

A paca extinta Cuniculus major é pouco conhecida e atualmente sua distribuição geográfica restringe-se à região de Lagoa Santa, Minas Gerais, onde a Gruta Cuvieri representa o limite norte de sua ocorrência. Cuniculus major apresenta proporções ósseas da ordem de 20 a 30\% maiores do que Cuniculus paca. As semelhanças morfológicas entre as espécies estudadas são marcantes, e uma vez que as demais espécies da família Cuniculidae, extintas (C. laticeps) e viventes (C. paca e $C$. taczanowskil), têm porte bastante similar, o tamanho dos ossos Cuniculus major representa um fator eficiente para diferenciar preliminarmente esta espécie das demais pacas conhecidas. 


\section{TAFONOMIA}

A análise tafonômica representa uma abordagem complementar à identificação anatômica e taxonômica, subsidiando uma melhor compreensão da formação do pacote fossilífero do Locus 3. Para caracterizar tafonomicamente o material, cada peça foi minuciosamente observada em busca de mudanças em sua superfície. Assim, a distribuição espacial dos fósseis apresentada neste capítulo considerou individualmente os diferentes aspectos observados no material sob uma perspectiva tafonômica.

\subsection{Material}

A análise tafonômica abrange os restos ósseos plotados e de peneira dos mamíferos de médio porte ( $>5$ e $<44 \mathrm{~kg}$ ) e de um táxon de grande porte (> $44 \mathrm{~kg}$ ) escavados no Locus 3 da Gruta Cuvieri. Foram consideradas também peças não identificadas anatômica e taxonomicamente pelo potencial informativo que elas apresentam do ponto de vista tafonômico. No total foram analisadas 6140 peças recuperadas nos Loci 3A e B.

Para a elaboração da reconstituição virtual da distribuição óssea utilizouse os desenhos das exposições descritos anteriormente no item Material do Capítulo 2 - Cura e identificação do material. Desta forma, somente as peças plotadas são representadas na reconstituição virtual.

\subsection{Métodos}

As análises tafonômicas realizadas consideram os fósseis segundo um conjunto de características de interesse, as quais são descritas a seguir. Para 
reconstituir virtualmente a distribuição espacial dos ossos em um ambiente tridimensional os desenhos das exposições foram processados da mesma forma descrita no item Método, do Capítulo 2 - Cura e identificação do material. A Figura 2.1 (Capítulo 2 - Cura e identificação do material) apresenta de maneira simplificada as etapas deste processamento, sendo que 0 procedimento detalhado consta no Anexo I.

\section{Distribuição dos fósseis segundo o grupo taxonômico}

A partir dos dados da identificação taxonômica a distribuição espacial dos fósseis foi representada virtualmente. Os ossos de cada grupo taxonômico, bem como aqueles de táxon indeterminado, foram considerados de duas maneiras. A primeira delas inclui todas as peças e a segunda, somente aquelas que se apresentavam articuladas ou com lógica anatômica. Por lógica anatômica consideram-se peças que não estavam efetivamente articuladas, mas que encontravam-se espacialmente próximas e de maneira análoga a da organização anatômica observada em esqueletos articulados.

\section{Estado de fragmentação}

Diversos processos biológicos e geológicos são responsáveis pela fragmentação de restos fósseis (Lyman, 1994a; Kos, 2003a). A fragmentação inevitavelmente determina propriedades importantes dos restos ósseos (e.g. tamanho e forma), influenciando seu potencial de preservação e transporte. $O$ estado de fragmentação de um espécime pode ser definido, relativamente, pelo percentual que o espécime representa perante o elemento esquelético do qual deriva. Desta forma, o registro desta característica seguiu o seguinte critério: 
espécime íntegro $=95-100 \%$; espécime fragmentado $=50-94 \%$; e fragmento $=$ $1-49 \%$.

\section{Exposição ao intemperismo climático}

Segundo o trabalho experimental de Behrensmeyer (1978), ossos expostos a intempéries climáticas apresentam alterações características, sendo que as mais evidentes são trincas longitudinais e esfoliação de suas superfícies. Isto por que as mudanças diárias no microclima ao redor dos ossos ocasionam, num primeiro momento, a degradação da matriz orgânica e, mais tarde, da inorgânica (Nielsen-Marsh et al., 2000). Como o período pelo qual os ossos ficam expostos às intempéries climáticas influencia a intensidade das mudanças Behrensmeyer (1978) definiu seis estágios para classificar os restos ósseos afetados por este fenômeno. É importante ressaltar que o trabalho experimental de Behrensmeyer (1978) foi realizado a céu aberto e que as variações diárias de temperatura e umidade nessas condições são muito superiores às observadas em ambientes cavernícolas. Logo, espera-se que tais feições manifestem-se de forma mais atenuada no material escavado na Gruta Cuvieri. Em função disso, a utilização dos estágios propostos por Behrensmeyer (1978) para classificar o material do Locus 3 seria inadequada. Optou-se, portanto, por registrar apenas a presença ou a ausência de trincas nos ossos analisados.

\section{Sinais de abrasão}

Modificações da superfície óssea caracterizadas por feições arredondadas e de aparência polida são causadas pelo atrito dos ossos tanto 
com a água, as partículas sedimentares em transporte e outros ossos, quanto com a matriz sedimentar em que os ossos estão depositados (Lyman, 1994a). A análise destas características possibilita obter, principalmente, informações relativas ao retrabalhamento hídrico sofrido pelos ossos. Tanto o arredondamento, quanto o polimento podem apresentar-se de maneira muito variada em diferentes peças, dificultando a determinação de estágios de exposição à abrasão. Por este motivo, registrou-se apenas a presença ou a ausência destas feições nos fósseis.

\section{Modificações produzidas por animais}

Vários animais, como carnívoros e roedores, são mencionados como agentes que alteram a superfície de remanescentes ósseos através de suas dentições (Fernandez-Jalvo et. al., 2002; Holz e Simões, 2002; Kos, 2003a e Lyman, 1994a). O comportamento apresentado por esses animais Ihes confere também o papel de potenciais acumuladores ou dispersores de material ósseo.

As marcas de dentes produzidas por carnívoros foram descritas e classificadas em alguns trabalhos (Binford, 1981; Haynes, 1983; Lyman, 1994a), sendo que em todos eles as mesmas feições foram observadas; porém, a denominação adotada por cada autor varia. Considerando a descrição minuciosa realizada por Binford (1981) quanto às marcas de dentes produzidas por carnívoros e as fotografias que ilustram suas descrições, a nomenclatura por ele proposta foi adotada neste trabalho através de traduções livres dos termos utilizados por aquele autor.

As marcas produzidas por roedores são muito distintivas, caracterizandose por sulcos longos, largos e paralelos (Miller, 2007), mas algumas vezes 
ossos muito alterados por estes animais apresentam múltiplos sulcos não paralelos e sobrepostos (Haglund, 1996). Assim, a análise das marcas de roedores presentes no material do Locus 3 considerou tanto as descrições mencionadas, quanto o detalhado registro fotográfico apresentado por Lyman (1994a).

\section{Distribuição de peças complementares}

Embora estudos que envolvam a remontagem de peças complementares consumam muito tempo (Larson e Ingbar, 1992), eles podem fornecer importantes informações sobre movimentos ocorridos após a deposição dos ossos e durante seu soterramento (Villa, 1982; Hofman, 1992). Tais movimentos podem ser detectados mesmo em depósitos paleontológicos/arqueológicos em que, aparentemente, as matrizes sedimentares não foram perturbadas (Villa, 1982). Existem diversos tipos de estudos baseados na remontagem de peças, sendo que aquele adotado neste trabalho é a remontagem mecânica. No caso do estudo de remanescentes ósseos, a remontagem mecânica consiste basicamente na união de fragmentos de um mesmo elemento esquelético (Todd e Frison 1992; Todd e Standford 1992). Uma vez que os fósseis de cada subdivisão do Locus 3 foram identificados anatômica e taxonomicamente, eles foram agrupados segundo o elemento esquelético, o lado e o taxon que representam (e.g. fêmures esquerdos de Tayassuidae do Locus 3A). A partir dos grupos formados, buscouse remontar as peças ali presentes. Esta procura por peças complementares foi realizada de maneira sistemática, verificando a possibilidade de remontagem de cada uma das peças com as demais incluídas no mesmo grupo. Na reconstituição virtual da distribuição espacial dos fósseis as peças que se 
complementam são unidas por uma linha que representa a distância entre elas e a orientação do movimento que as distanciou.

\subsection{Resultados}

A seguir são apresentados os resultados das análises tafonômicas referentes ao material exumado do Locus 3 da Gruta Cuvieri.

\section{Distribuição dos fósseis segundo o grupo taxonômico}

Na Figura 3.1 é possível observar a disposição geral das peças plotadas em relação aos eixos de referência a partir da vista de perspectiva sudeste. Nesta figura verifica-se que os grupos taxonômicos, bem como as peças de táxon indeterminado, ocupam amplamente toda a área escavada (Figura 3.1). Observa-se também que a distribuição das peças de cada grupo é bastante heterogênea, com peças mais ou menos abundantes em determinadas regiões da área escavada (Figura 3.1). Para que se possa verificar mais claramente a distribuição dos ossos de cada grupo taxonômico, bem como dos ossos não identificados taxonomicamente, num primeiro momento os dados serão apresentados separadamente em dois conjuntos, sendo: 1) ossos de C. major, C. paca e Cervidae; e 2) Tayassuidae, P. onca e táxon indeterminado. A distribuição das peças é apresentada em vista de planta e de perfil leste, pois a análise combinada destas vistas provê melhores condições de avaliação da posição dos fósseis no espaço escavado.

Na Figura 3.2 é possível observar a distribuição horizontal e vertical dos ossos do primeiro conjunto. Na vista de planta observa-se que os restos de $C$. major (esferas azuis) apresentam-se bastante concentrados no Locus 3A, 


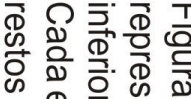

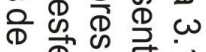

ก这

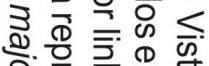

$\therefore$ 㑒

का का ก 요

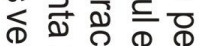

융 $\frac{1}{3}$.

员尔

雨於

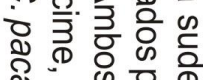

is

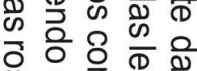

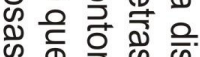

융ำ

ญ유

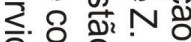

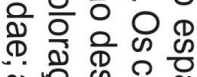

क "

곡 응 윽

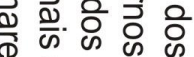

क 他

음 $\stackrel{\bar{D}}{\mathbb{D}} \stackrel{\mathbb{D}}{\mathbb{D}}$.

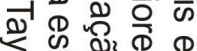

足

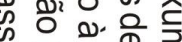

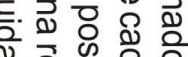

赵

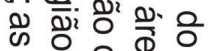

은 응으.

象

क व

유응. 워 $\omega$

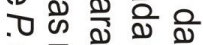

구용

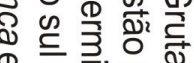

为

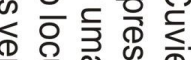

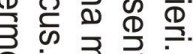

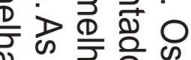

요은

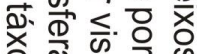

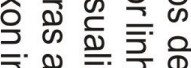

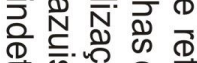

का के

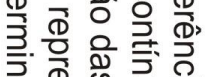

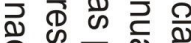

응 क्ष

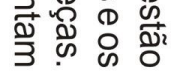

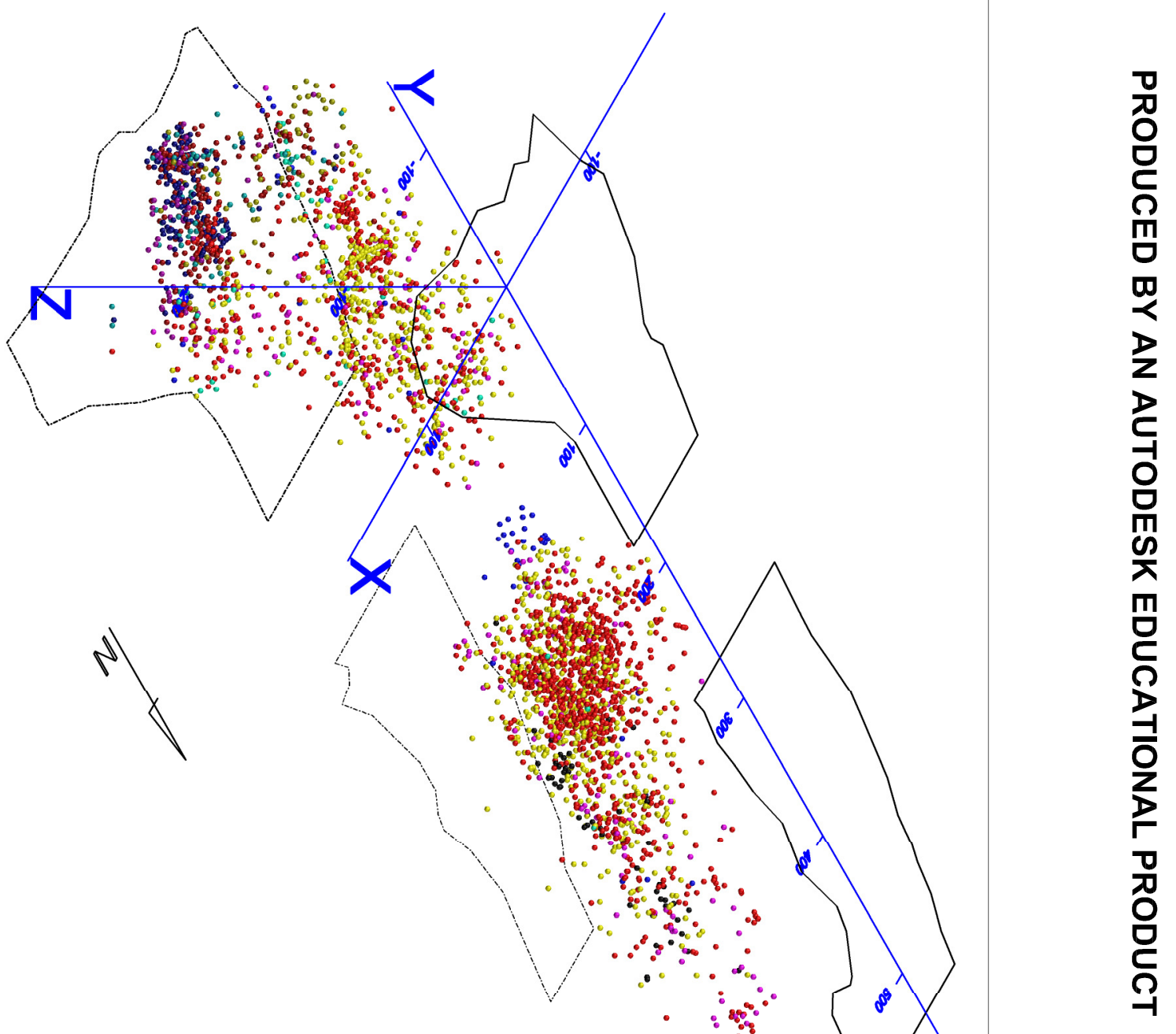




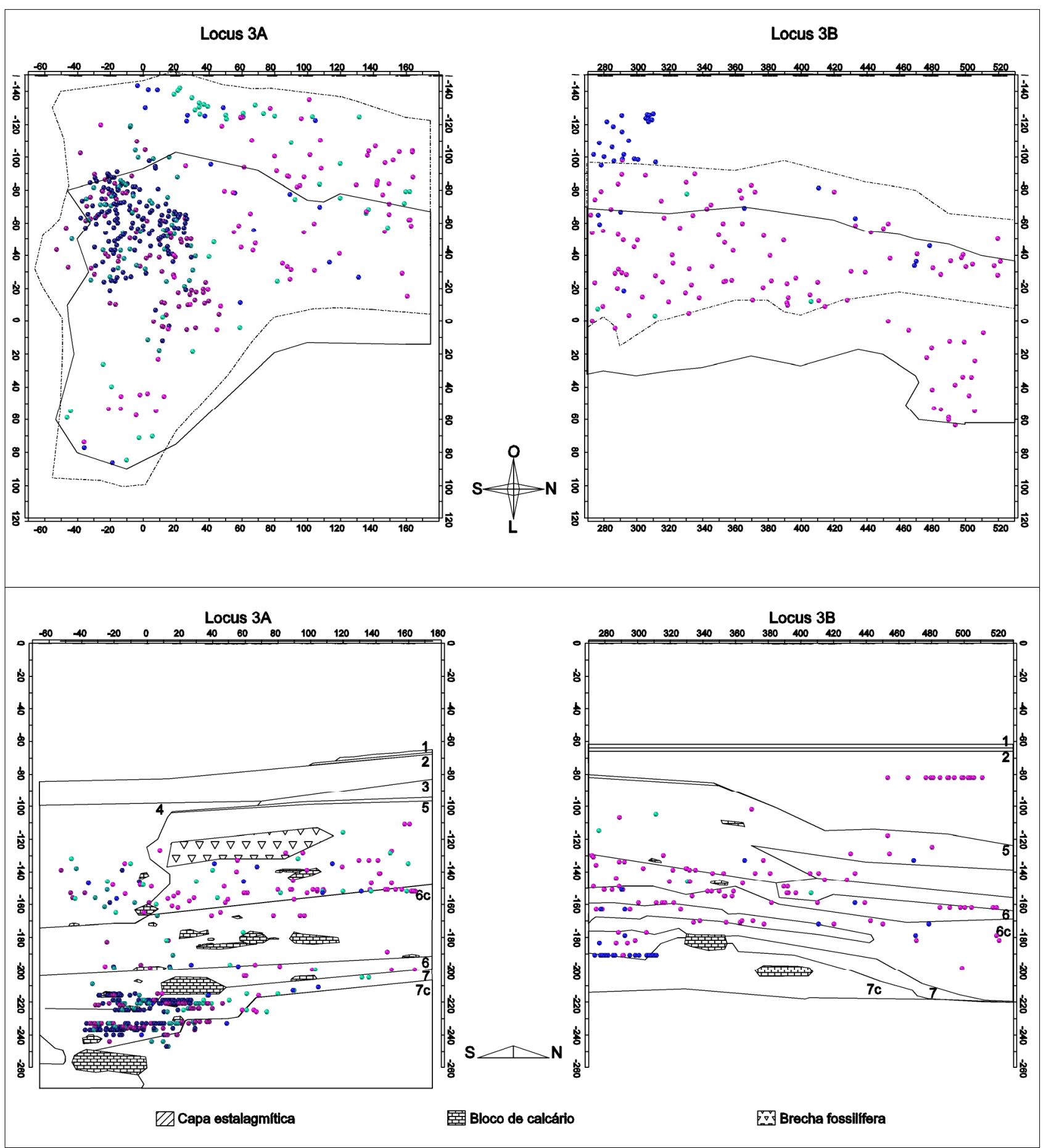

Figura 3.2 - Distribuição espacial dos fósseis de C. major, C. paca e Cervidae. Acima vista de planta, abaixo vista leste. As esferas azuis representam restos de C. major, as verdes de C. paca e as rosas de Cervidae. Cada esfera representa um espécime, sendo que as de coloração mais escura estão na região das bacias no sul do locus. Na vista de planta o contorno superior das paredes do locus está representado em linha contínua e o inferior em tracejada. 
No Locus $3 \mathrm{~B}$ as peças de C. major localizam-se principalmente na região sudoeste, com pouquíssimas peças mais a norte (Figura 3.2). No plano vertical do Locus $3 \mathrm{~A}$ os ossos de C. major distribuem-se principalmente nas fácies $6 \mathrm{e}$ 7 inconsolidadas, com algumas peças nos limites inferior e superior das fácies 6 e 7 consolidadas, respectivamente (Figura 3.2). Outros ossos da espécie ocorrem esparsos nas metades inferiores das fácies 4 e 5 (Figura 3.2). No Locus $3 \mathrm{~B}$ as peças de C. major encontram-se principalmente nos limites entre as fácies 7 e 7 consolidada, sendo que poucas peças distribuem-se pelas fácies 5, 6 e 6 consolidada (Figura 3.2).

Na vista de planta da Figura 3.2 verifica-se que C. paca (esferas verdes) tem peças distribuídas de maneira esparsa por grande parte do Locus $3 \mathrm{~A}$, tanto na área das bacias quanto fora delas. No Locus 3B as peças desta espécie são escassas e restringem-se ás regiões sul e central (Figura 3.2). Verticalmente os ossos de C. paca distribuem-se principalmente pelas fácies $4,5,6$ e 7 do Locus 3A, com menor número de peças nas fácies 6 e 7 consolidadas (Figura 3.2). Os raros ossos de C. paca encontrados no Locus 3B ocorrem nas fácies 5, 6 e 6 consolidada (Figura 3.2).

A vista de planta da Figura 3.2 permite observar que os restos de Cervidae (esferas rosas) encontram-se dispersos de maneira bastante ampla em ambas as subdivisões do Locus 3. A distribuição vertical deste táxon no Locus $3 A$ dá-se nas fácies 6 e 7, com poucas peças na fácies 6 consolidada, as quais, ocorrem nas imediações dos limites inferior e superior desta fácies (Figura 3.2). Na metade inferior das fácies 4 e 5 os ossos de Cervidae voltam a ser mais abundantes (Figura 3.2). No plano vertical do Locus 3B observa-se pequena quantidade de restos de Cervidae na área sul da fácies 7 , com maior 
ocorrência nas fácies 6 e 6 consolidada (Figura 3.2). Nas fácies 2 e 5 encontrase um número menor de ossos de Cervidae, sendo que aqueles da fácies 2 representam um mesmo indivíduo e encontram-se bastante concentrados horizontal e verticalmente (Figura 3.2).

A Figura 3.3 exibe a distribuição dos restos fósseis dos animais incluídos no segundo grupo. É possível observar que no Locus $3 A$ as peças pertencentes a Tayassuidae (esferas amarelas) apresentam ampla distribuição horizontal, sendo sensivelmente menos abundantes no terço sul (Figura 3.3). No Locus $3 \mathrm{~B}$ os ossos deste táxon também ocupam a maior parte da área escavada, mas sua abundância diminui gradualmente a medida que se avança de sul para norte (Figura 3.3). Como se pode observar na vista leste da Figura 3.3 os restos de Tayassuidae encontram-se principalmente nas fácies 4 e 5 . Na primeira as peças localizam-se exclusivamente na metade inferior, enquanto que na segunda alguns fósseis ocupam também a metade superior. Na fácies 6 consolidada do Locus 3A as peças de Tayassuidae são menos abundantes e apresentam-se bastante dispersas (Figura 3.3). Ainda no Locus 3A os ossos de Tayassuidae encontram-se nas fácies 6 e 7, alguns deles localizados na área das bacias (Figura 3.3).

No plano vertical do Locus 3B os restos de Tayassuidae ocorrem principalmente no terço sul (Figura 3.3). Nas fácies 6 e 6 consolidada há uma gradativa redução na quantidade de peças deste táxon conforme se avança no sentido norte (Figura 3.3). No terço médio da fácies 6 consolidada há uma pequena concentração de ossos relativamente isolados dos demais logo abaixo de uma brecha fossilífera. Mais ao norte, a mesma fácies apresenta maior amplitude vertical assim como os ossos que ali ocorrem (Figura 3.3). Nas 


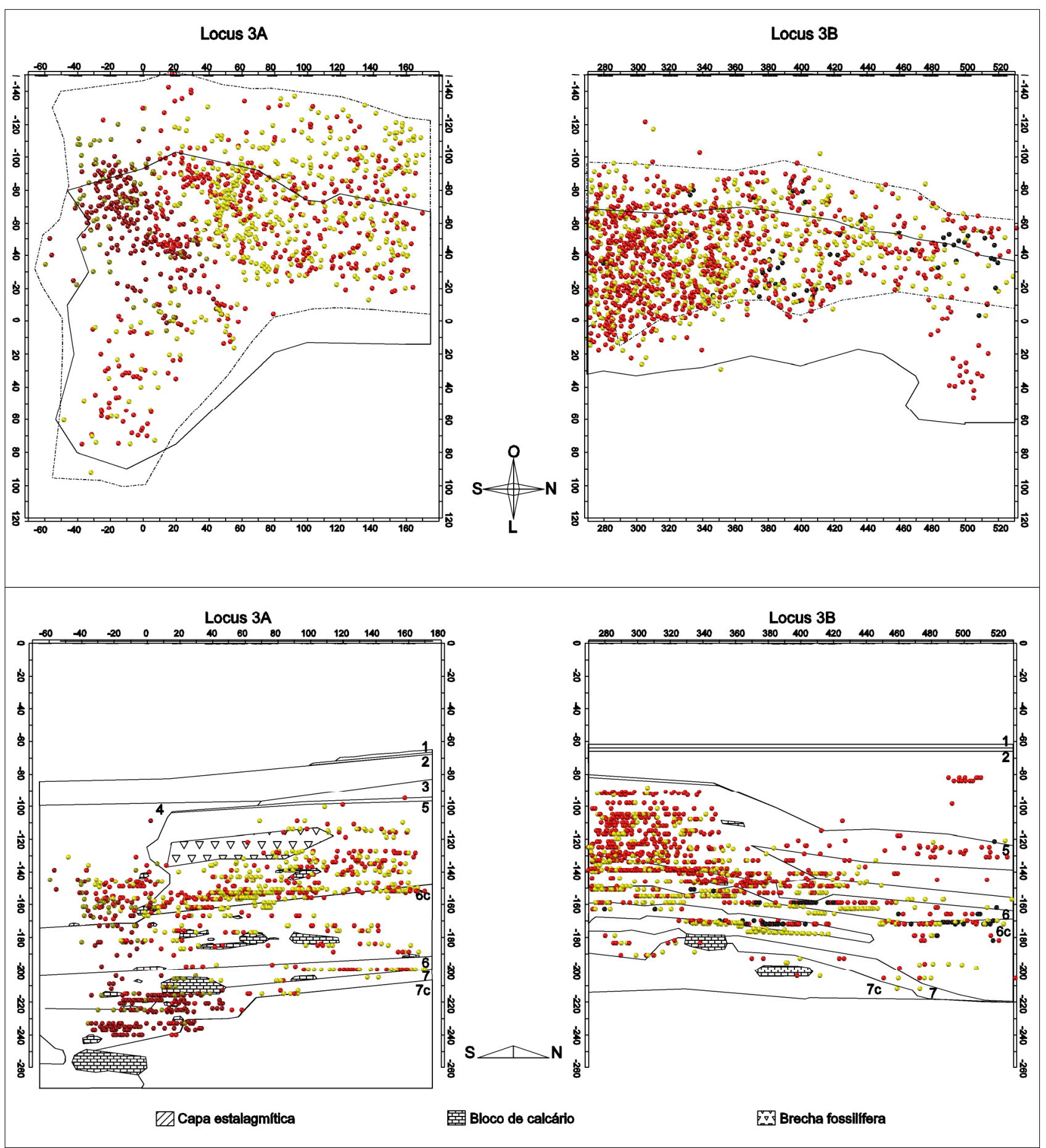

Figura 3.3 - Distribuição espacial dos fósseis de Tayassuidae, P. onca e de taxon indeterminado. Acima vista de planta, abaixo vista leste. As esferas amarelas representam restos de Tayassuidae, as pretas de $P$. onca e as vermelhas de táxon indeterminado. Cada esfera representa um espécime, sendo que os de coloração mais escura estão na região das bacias no sul do locus. Na vista de planta o contorno superior das paredes do locus está representado em linha contínua e o inferior em tracejada. 
fácies 7 e 7 consolidada o número de ossos de Tayassuidae é bastante reduzido e eles distribuem-se principalmente próximos ao contato entre as fácies (Figura 3.3).

Observando a Figura 3.3 verifica-se ainda que os restos de $P$. onca (esferas pretas) estão restritos ao Locus 3B e distribuem-se principalmente nos terços central e norte da área escavada. Verticalmente as peças ocorrem em maior quantidade na fácies 6 consolidada e a maioria daquelas localizadas no terço central da fácies coincidem com a brecha nela imersa (Figura 3.3). As peças situadas no terço norte estão, em sua maior parte, muito próximas do contato com a parte inferior da fácies 6 (Figura 3.3). Alguns restos de $P$. onca ocorrem também na fácies 6 , sobretudo, na área central. Verifica-se também na Figura 3.3 que apenas uma peça localiza-se bem acima das demais, na parte norte do contato entre as fácies 2 e 5. Desconsiderando esta peça o esqueleto de $P$. onca distribui-se verticalmente por uma faixa de aproximadamente $30 \mathrm{~cm}$.

Na vista de planta da Figura 3.3 é possível observar que as peças não identificadas taxonomicamente (esferas vermelhas) distribuem-se amplamente pela área escavada de todo o Locus 3. Na subdivisão A do locus a distribuição é relativamente homogênea, com uma pequena concentração na área das bacias (Figura 3.3). No Locus 3B observa-se gradual decréscimo na abundância de peças à medida que se avança de sul para norte (Figura 3.3).

No plano vertical constata-se que os restos não identificados taxonomicamente são encontrados em todas as fácies (Figura 3.3). No Locus 3A parte das peças está concentrada na área das bacias das fácies 6 e 7 (Figura 3.3), enquanto um pequeno número delas ocorre de maneira bastante difusa na fácies 6 consolidada (Figura 3.3). Os restos não identificados 
localizados na fácies 4 , e na área da fácies 5 adjacente a primeira, encontramse principalmente em sua metade inferior (Figura 3.3). Na área norte da fácies 5 os ossos não identificados ocorrem na metade inferior e, em menor número, na superior (Figura 3.3).

Na vista leste do Locus 3B observa-se que na fácies 2 encontram-se algumas peças concentradas na área norte (Figura 3.3). Observa-se também que os ossos não identificados distribuem-se principalmente no terço sul das fácies 5 e 6 e diminuindo em quantidade no sentido norte (Figura 3.3). Nas fácies 6 consolidada, 7 e 7 consolidada as peças são bem menos abundantes, sendo que na primeira e na última as peças não identificadas localizam-se na parte superior das respectivas fácies (Figura 3.3).

A Figura 3.4 permite visualizar exclusivamente a distribuição de peças articuladas e com proximidade anatômica. Na vista de topo do Locus 3A verifica-se três concentrações de peças nestas condições, sendo duas de Tayassuidae (esferas amarelas) - uma menor na região sudoeste (ossículos do carpo, metacarpos e falanges) e outra maior na região central (vértebras, sacro, costelas e pata dianteira) - e uma de C. major (esferas azuis), também na área central (mandíbula, átlas, dois fragmentos de áxis e mais duas vértebras cervicais; Figura 3.4). A vista de planta do Locus $3 B$ exibe quatro concentrações: uma de C. major (esferas azuis) na região sudoeste (pélvis, sacro, vértebras caudais e lombares, fêmur, tíbia, metatarsos e falanges); uma de $P$. onca (esferas pretas) na área central (calcâneo, metatarso e falanges); uma de Tayassuidae (esferas amarelas; falanges) também no centro e uma de Cervidae (esferas rosas) na região nordeste (pélvis, sacro, vértebras, escápula, costelas, fêmures, rádioulnas e metapódios; Figura 3.4). 


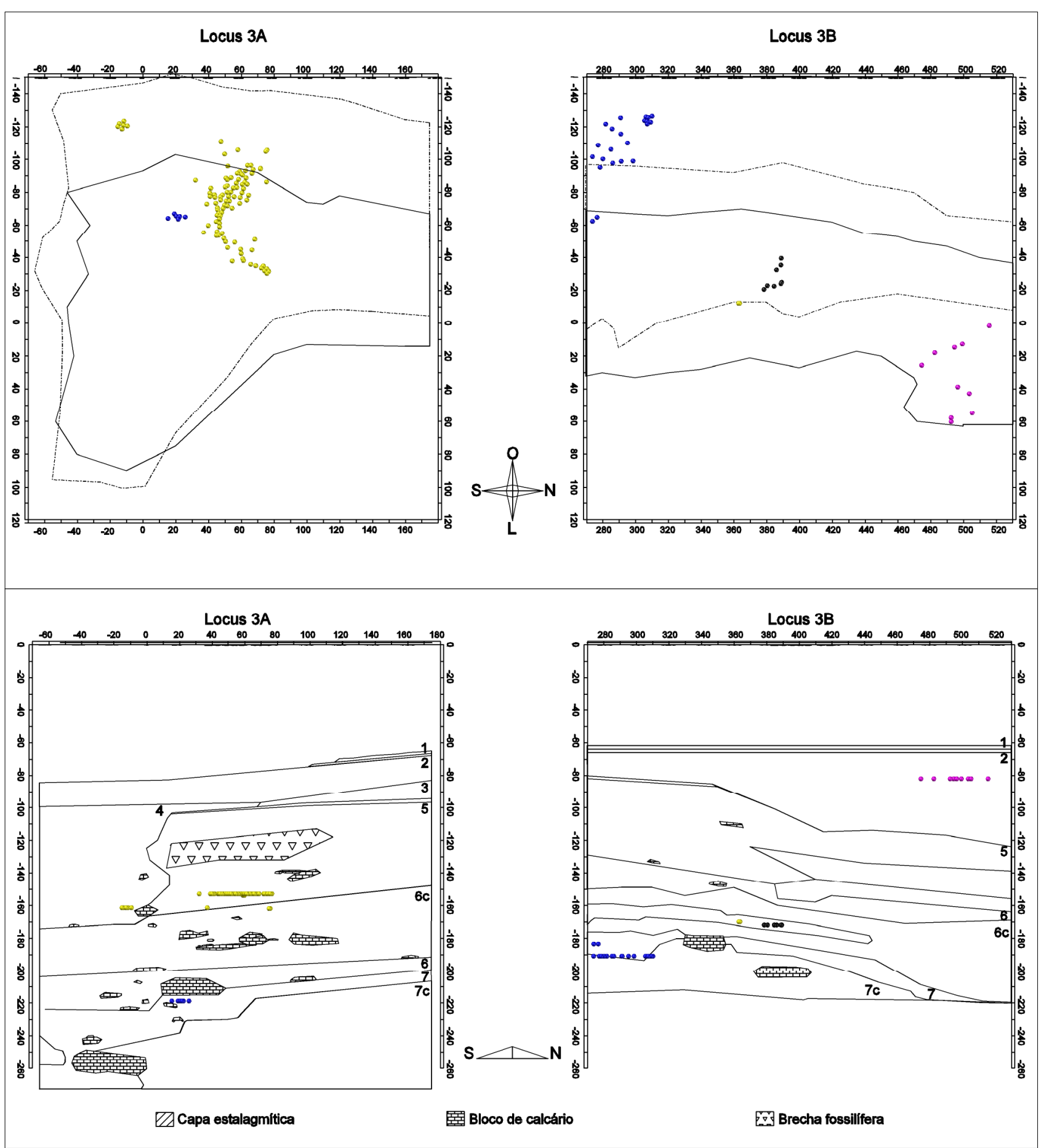

Figura 3.4 - Distribuição espacial dos ossos articulados e com lógica anatômica. Acima vista de planta, abaixo vista leste. Cada esfera representa um espécime. As esferas azuis representam restos de C. major, as rosas de Cervidae, as amarelas de Tayassuidae e as pretas de $P$. onca. Na vista de planta o contorno superior das paredes do locus está representado em linha contínua e o inferior em tracejada. 
A vista leste da Figura 3.4 mostra que a menor das concentrações ósseas de Tayassuidae do Locus $3 \mathrm{~A}$ está na fácies 4 , enquanto que a maioria das peças da concentração maior ocorre na fácies 5 e os ossos de C. major ocorrem na fácies 7 (Figura 3.4). Na vista de perfil do Locus 3B (Figura 3.4) verifica-se que as peças de C. major estão nas imediações do contato entre as fácies 7 e 7 consolidada, ao passo que as concentrações de Tayassuidae e de P. onca ocorrem na fácies 6 consolidada, coincidindo com a brecha de ossos ali imersa. No plano vertical da Figura 3.4 verifica-se ainda que a concentração de ossos de Cervidae ocorre na fácies 2.

\section{Estado de fragmentação}

Os espécimes íntegros totalizam 1026 peças (16,7\%), sendo que 640 $(10,4 \%)$ ocorrem no Locus 3A e $386(6,3 \%)$ no Locus 3B. Os espécimes fragmentados reúnem 1428 peças $(23,3 \%)$, das quais 955 (15,6\%) provêm do Locus $3 \mathrm{~A}$ e $473(7,7 \%)$ do Locus 3B. Os fragmentos somam $3682(60,0 \%)$ peças, $1471(24,0 \%)$ no Locus 3A e $2211(36,0 \%)$ no Locus 3B.

Na Figura 3.5 é possível observar o percentual de espécimes por parte anatômica para cada estado de fragmentação e considerando cada subdivisão do Locus 3 separadamente. Na Figura 3.5, A observa-se que, no que se refere às peças íntegras, tanto o Locus $3 \mathrm{~A}$ quanto $\circ 3 \mathrm{~B}$ apresentam freqüências semelhantes, com pequenas diferenças nos metapódios - cujo percentual é maior no primeiro - e nos ossos do carpo/tarso e nas falanges - para o qual o percentual é maior no segundo. Já na Figura $3.5, \mathrm{~B}$, que se refere às peças fragmentadas, verifica-se que o Locus $3 \mathrm{~A}$ apresenta um maior percentual para mandíbulas, vértebras, costelas, escápulas, pélvis, radioulna/rádio e ulna, ao 

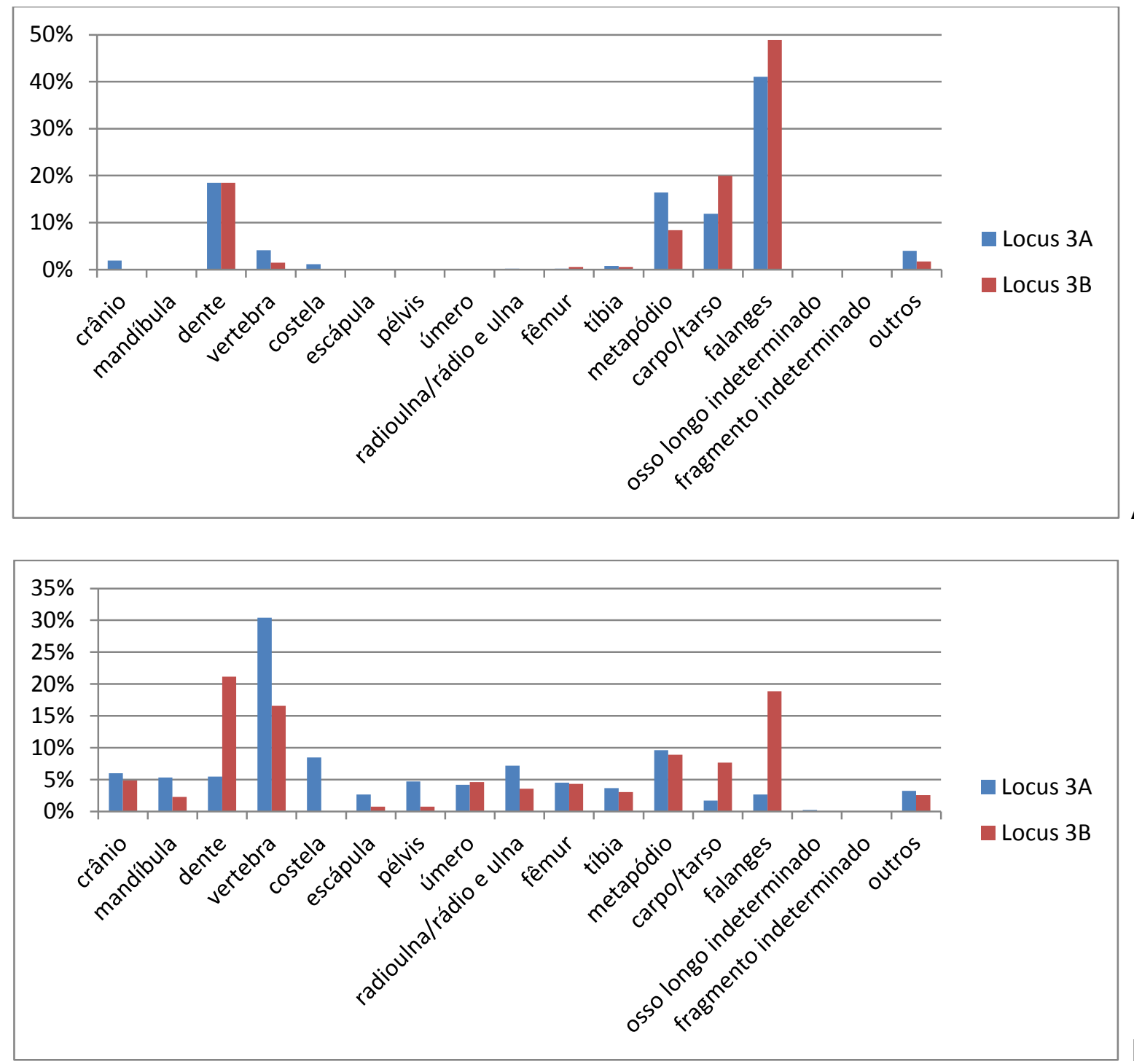

B

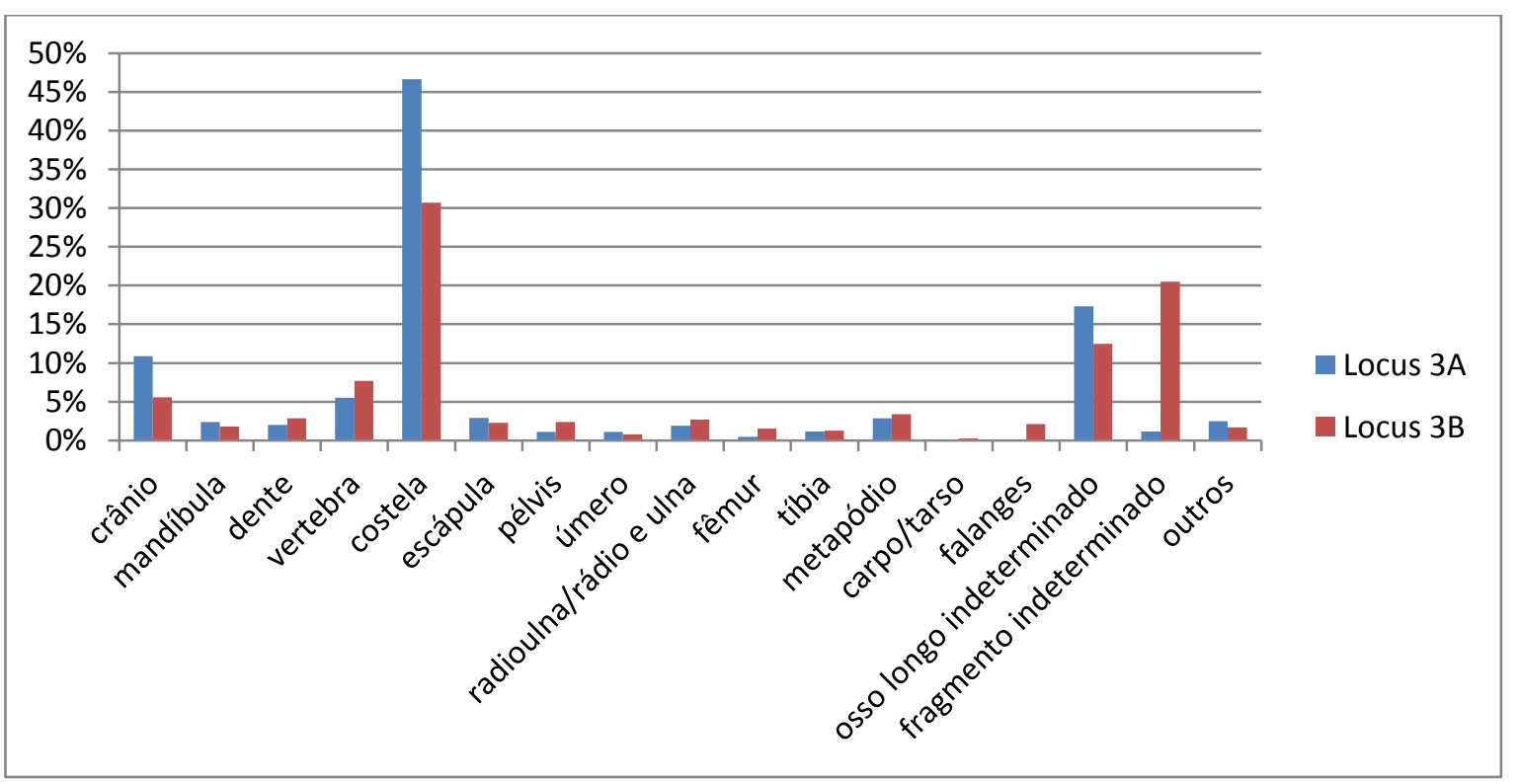

Figura 3.5 - Percentual de espécimes por parte anatômica para cada estado de fragmentação e considerando cada subdivisão do Locus 3 como uma totalidade. A: espécimes íntegros; B: espécimes fragmentados; C: fragmentos. 
passo que, no Locus 3B isso ocorre apenas para dentes, ossos do carpo/tarso e falanges. No que tange aos fragmentos, na Figura 3.5,C verifica-se que ambas as sudivisões do Locus 3 apresentam percentuais relativamente similares. As diferenças ocorrem principalmente para fragmentos de crânio, costela e osso longo indeterminado - que são mais abundantes no Locus $3 \mathrm{~A}$ - e para fragmentos indeterminados, que são mais abundantes no Locus 3B.

A Figura 3.6 exibe a distribuição espacial das peças segundo o estado de fragmentação. Na vista de planta verifica-se que os espécimes íntegros são os menos abundantes, mas distribuem-se por toda a superfície escavada do Locus 3A e B (Figura 3.6). Situação semelhante é a dos espécimes fragmentados e fragmentos, mas os primeiros formam uma pequena concentração na área central do Locus $3 \mathrm{~A}$, enquanto os últimos encontram-se concentrados principalmente no terço sul do Locus 3B e gradativamente escasseiam no sentido norte (Figura 3.6). No plano vertical da Figura 3.6 é possível verificar que os espécimes íntegros ocorrem em praticamente todas as fácies, desde aquelas mais profundas, como as 6 e 7, passando pela fácies 6 consolidada até as fácies 2, 4 e 5, mais acima. Os espécimes fragmentados e fragmentos apresentam distribuições semelhantes a das peças íntegras, mas os últimos concentram-se na fácies 5 do Locus 3B, na metade sul (Figura 3.6). 

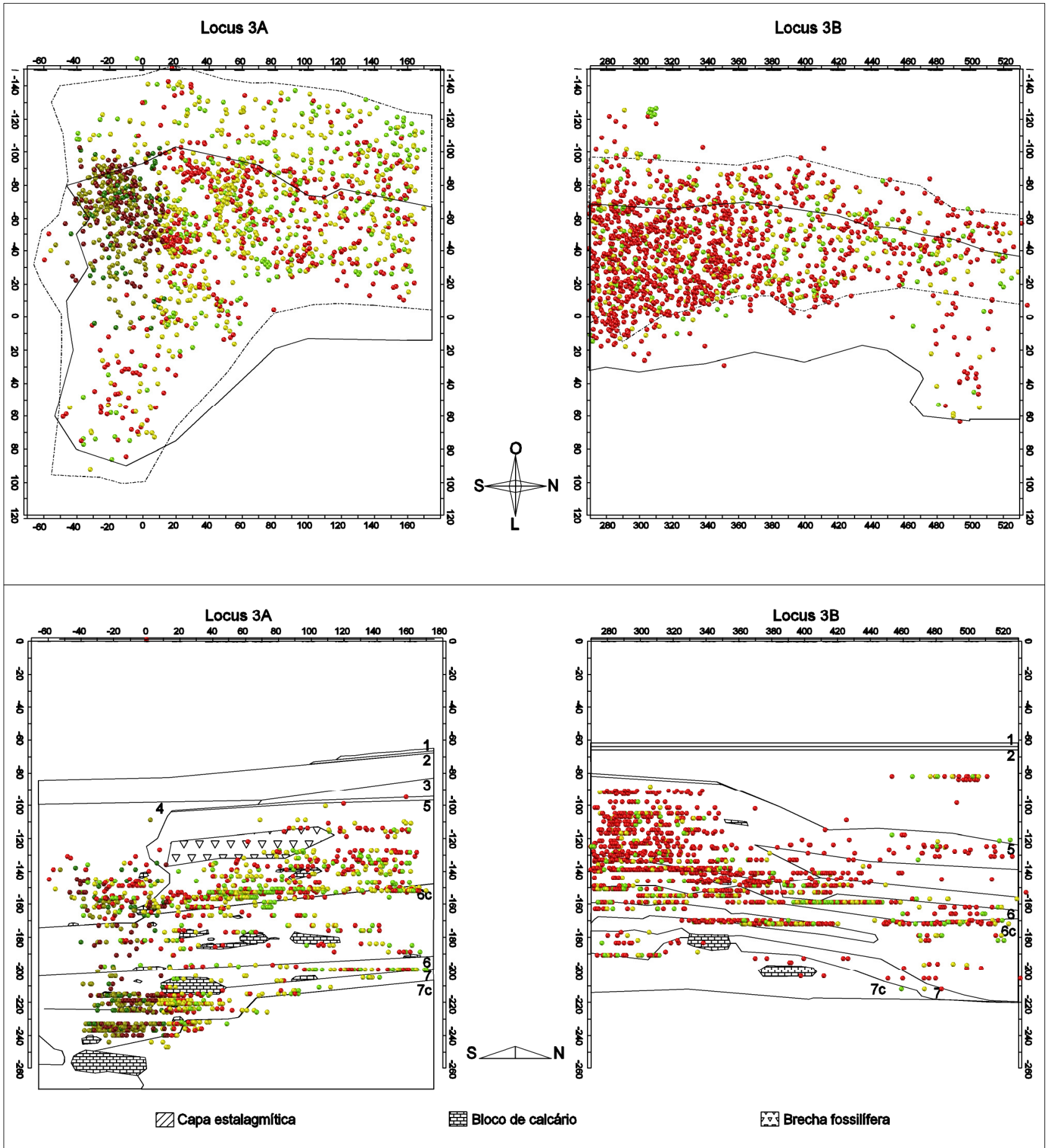

Figura 3.6 - Distribuição espacial dos ossos segundo o estado de fragmentação. Acima vista de planta, abaixo vista leste. Cada esfera representa um espécime, sendo que as de coloração mais escura estão na região das bacias no sul do locus. As esferas verdes representam peças íntegras, as amarelas peças fragmentadas e as vermelhas os fragmentos. Na vista de planta o contorno superior das paredes do locus está representado em linha contínua e o inferior em tracejada. 


\section{Exposição a intempéries climáticas}

Em 1332 (21,69\%) peças foi possível detectar a presença de feições associadas a intempéries climáticas. Deste total, 517 (8,42\%) foram escavadas no Locus $3 \mathrm{~A}$ e $815(13,27 \%)$ no 3B. Apesar de a coleta destes dados ter sido feita considerando apenas a presença ou ausência de trincas nos ossos, foi possível observar peças afetadas em diferentes intensidades.

A Figura 3.7 ilustra esta observação em alguns ossos longos, sendo A e B exemplos de ossos mais afetados - com múltiplas trincas distribuídas amplamente - enquanto C e D representam ossos menos afetados - com poucas trincas de ocorrência localizada.

Na Figura 3.8 é possível observar a distribuição dos ossos com feições associadas ao intemperismo climático. Na vista de topo verifica-se que ossos intemperizados estão dispersos por praticamente toda a superfície do locus (Figura 3.8). No Locus 3A observa-se uma distribuição relativamente uniforme, com exceção do extremo sudeste, onde a densidade de peças é levemente menor (Figura 3.8). No Locus 3B as peças estão mais proximamente associadas do que no Locus 3A e sua distribuição diminui de forma gradativa do sentido sul para norte (Figura 3.8).

Na vista leste da Figura 3.8 observa-se que no Locus 3A que uma pequena parte das peças intemperizadas está concentrada na área das bacias das fácies 6 e 7, com poucas peças na área norte destas fácies. Na fácies 6 consolidada a densidade de peças diminui até aproximar-se do contato com as fácies 4 e 5 onde as peças intemperizadas são abundantes, sobretudo, na metade inferior das fácies (Figura 3.8). 

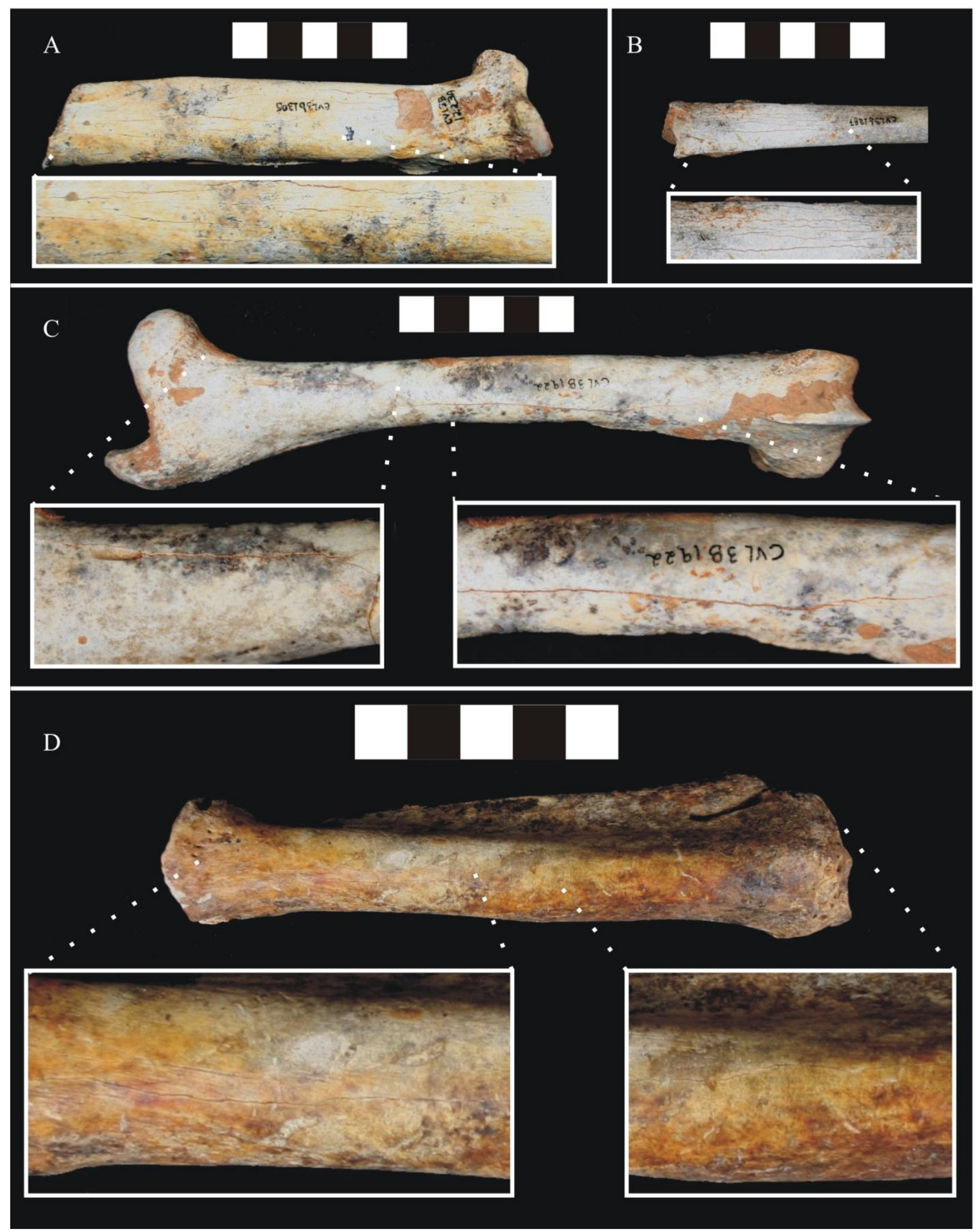

Figura 3.7 - Ossos com feições associadas ao intemperismo climático. A (rádio esquerdo de Panthera onca) e B (metatarso direito de Cervidae) representam ossos mais intensamente intemperizados, apresentando feixes com múltiplas trincas longitudinais de maneira generalizada sobre a superfície óssea. C (fêmur direito de Cervidae) e D (radioulna esquerda de Tayassuidae) representam ossos menos afetados pelas intempéries, apresentando apenas trincas localizadas, e no caso de $D$, de maneira bastante tênue. 

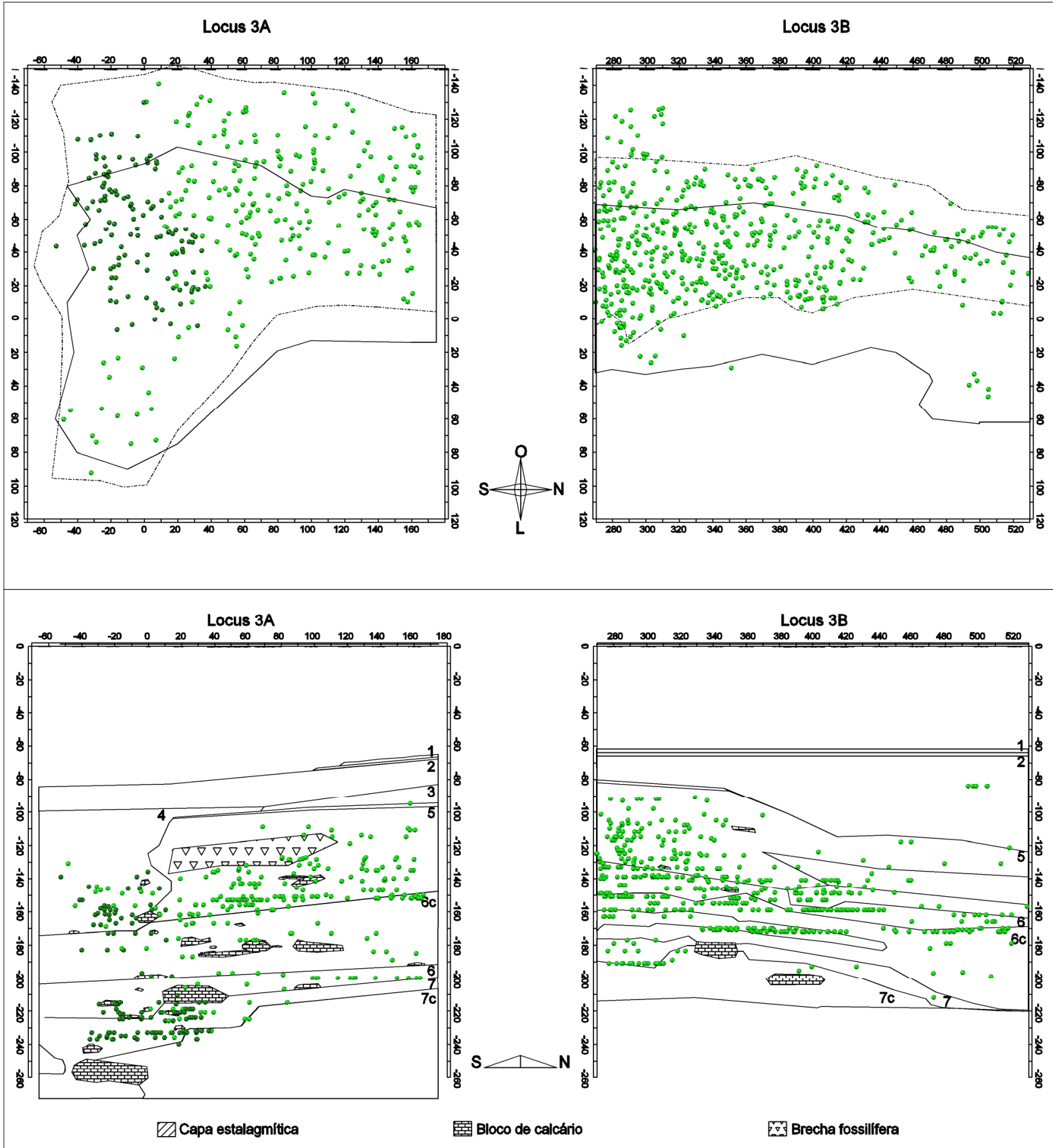

Figura 3.8 - Distribuição espacial dos ossos com sinais de exposição a intempéries climáticas. Acima vista de planta, abaixo vista leste. Cada esfera representa um espécime, sendo que as de coloração mais escura estão na região das bacias no sul do locus. Na vista de planta o contorno superior das paredes do locus está representado em linha contínua e o inferior em tracejada. 
O Locus 3B, na vista leste da Figura 3.8, apresenta ossos intemperizados em pequena quantidade nas fácies 7 e 7 consolidada. As fácies 6 e 6 consolidada concentram a maior parte das peças intemperizadas, sendo que na área mais profunda da região norte da fácies 6 consolidada as peças são mais escassas (Figura 3.8). Na fácies 5 os ossos expostos ao intemperismo localizam-se principalmente na metade sul do locus, com poucas peças mais a norte (Figura 3.8). A fácies 2 apresenta poucos ossos intemperizados, os quais, ocorrem exclusivamente na parte norte de sua distribuição (Figura 3.8)

\section{Sinais de abrasão}

Verificou-se que 553 (9\%) peças apresentam sinais de abrasão, das quais $396(6,44 \%)$ ocorrem no Locus 3A e 157 ( 2,55\%) no 3B. A Figura 3.9 permite visualizar algumas peças que exemplificam modificações generalizadas (A e B) e localizadas, sendo que em C e D observam-se ossos com abrasão de superfícies fragmentadas e em E um calcâneo direito de Cervidae com intensa abrasão na região lateral que removeu o tecido compacto e parte do trabecular. Atente para o fato de que a região mesial do calcâneo (Figura 3.9, E porção superior) permaneceu intacta. Na mesma figura, F indica uma vértebra lombar de Cuniculus major e G um metatarso de Tayassuidae que, assim como o calcâneo de Cervidae (Figura 3.9, E), apresentam abrasão localizada formando uma superfície aproximadamente plana.

A distribuição espacial das peças que apresentam sinais de abrasão pode ser observada na Figura 3.10. Na vista de topo verifica-se que no Locus 3A há uma sensível concentração de peças na área das bacias das fácies 6 e 7 


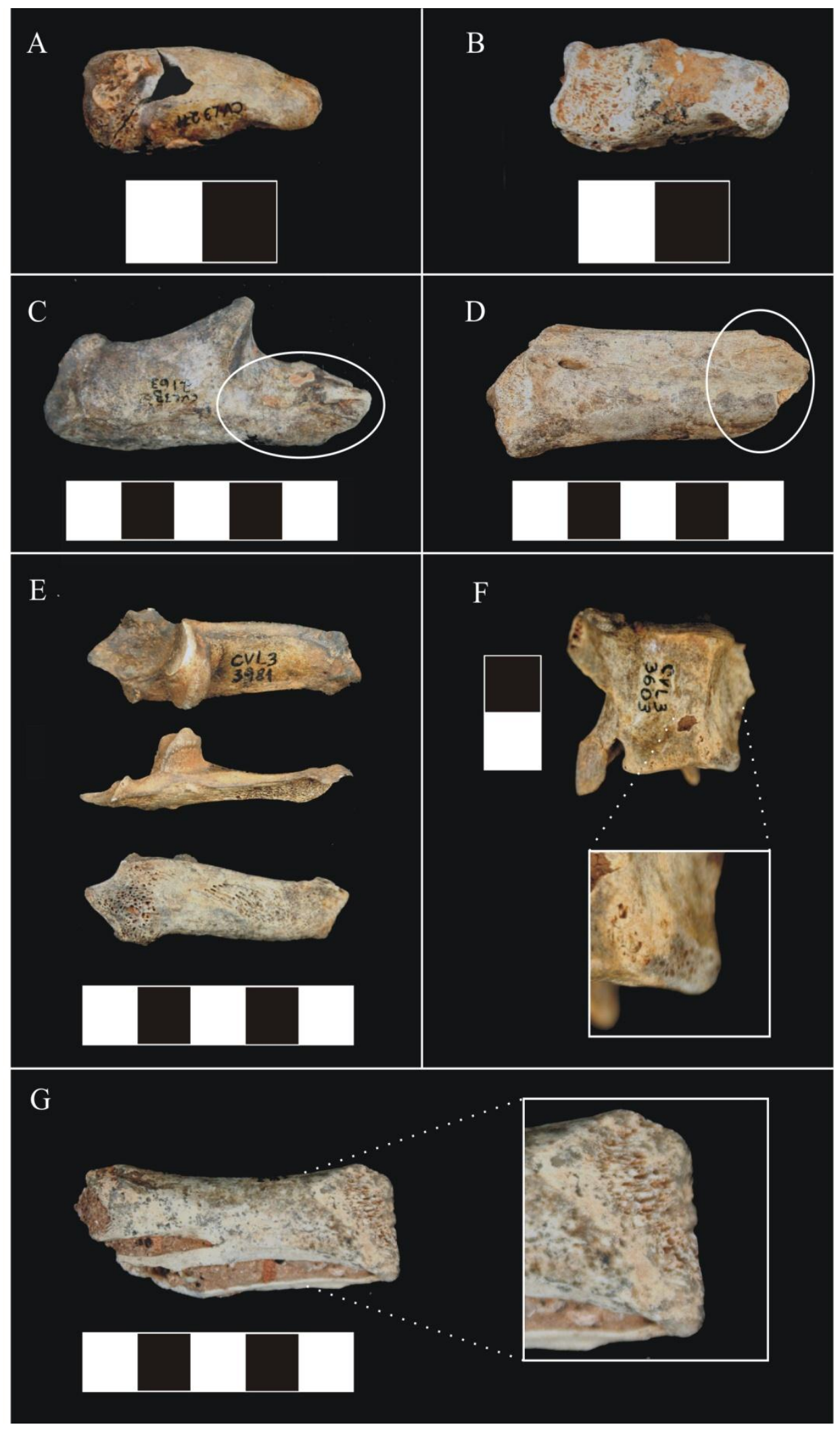

Figura 3.9 - Ossos que apresentam sinais de abrasão. A e B são falanges proximais de Artyodactila que apresentam abrasão generalizada. C e D são exemplos de ossos com abrasão de superfícies fragmentadas. E (calcâneo direito de Cervidae), F (vértebra lombar de Cuniculus major.) e G (metatarso de Tayassuidae) apresentam abrasão localizada com aspecto plano. 


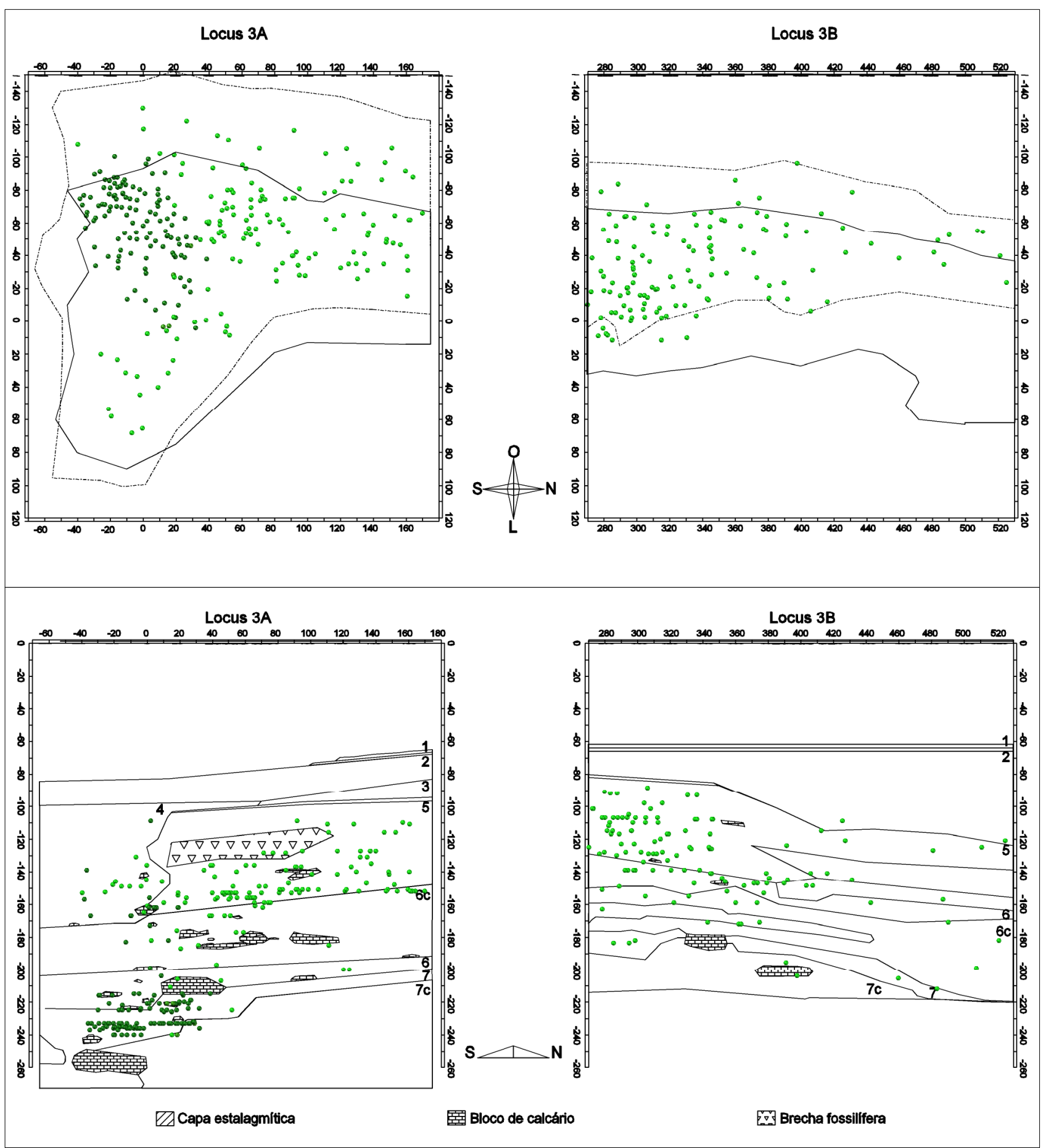

Figura 3.10 - Distribuição espacial dos ossos com sinais de abrasão. Acima vista de planta, abaixo vista leste. Cada esfera representa um espécime, sendo que as de coloração mais escura estão na região das bacias no sul do locus. Na vista de planta o contorno superior das paredes do locus está representado em linha contínua e o inferior em tracejada. 
e que no Locus 3B as peças diminuem gradativamente em quantidade a medida que se avança no sentido sul (Figura 3.10).

No plano vertical da Figura 3.10 percebe-se que a maior parte dos ossos com sinais de abrasão que ocorrem na área das bacias, está na verdade, naquela formada pela fácies 7 e em menor escala na fácies 6 (Figura 3.10). Na fácies 6 consolidada as peças abrasonadas são pouco abundantes e distribuem-se principalmente no terço central da fácies (Figura 3.10). Tanto na fácies 4, quanto na 5 , as peças são mais freqüentes na metade inferior (Figura 3.10). No Locus 3B as peças estão verticalmente concentradas no terço sul da

fácies 5, com poucas peças mais a norte (Figura 3.10). O mesmo pode ser observado para as fácies 6 e 6 consolidada (Figura 3.10). Nas fácies 7 e 7 consolidada as peças são escassas e não se concentram em nenhuma área específica (Figura 3.10)

\section{Modificações produzidas por animais: Roedores}

Os ossos apresentando marcas produzidas por estes animais totalizaram $68(1,10 \%)$ peças, sendo $31(0,5 \%)$ do Locus $3 \mathrm{~A}$ e $37(0,6 \%)$ do 3B. Na Figura 3.11 é possível visualizar algumas peças em que o volume de tecido ósseo removido é relativamente pequeno (A e B) quando comparado a aquele retirado em outras (C e D). Na maioria dos ossos as marcas foram produzidas nas diáfises, mas em raros casos elas ocorrem nas epífises (Figura 3.11, E).

A distribuição das peças com marcas da ação de roedores pode ser observada na Figura 3.12. Na vista de topo constata-se que as peças são pouco mais abundantes na metade sul do Locus 3A e que no Locus 3B elas distribuemse em três pequenos grupos, um em cada terço do locus (áreas sul, 

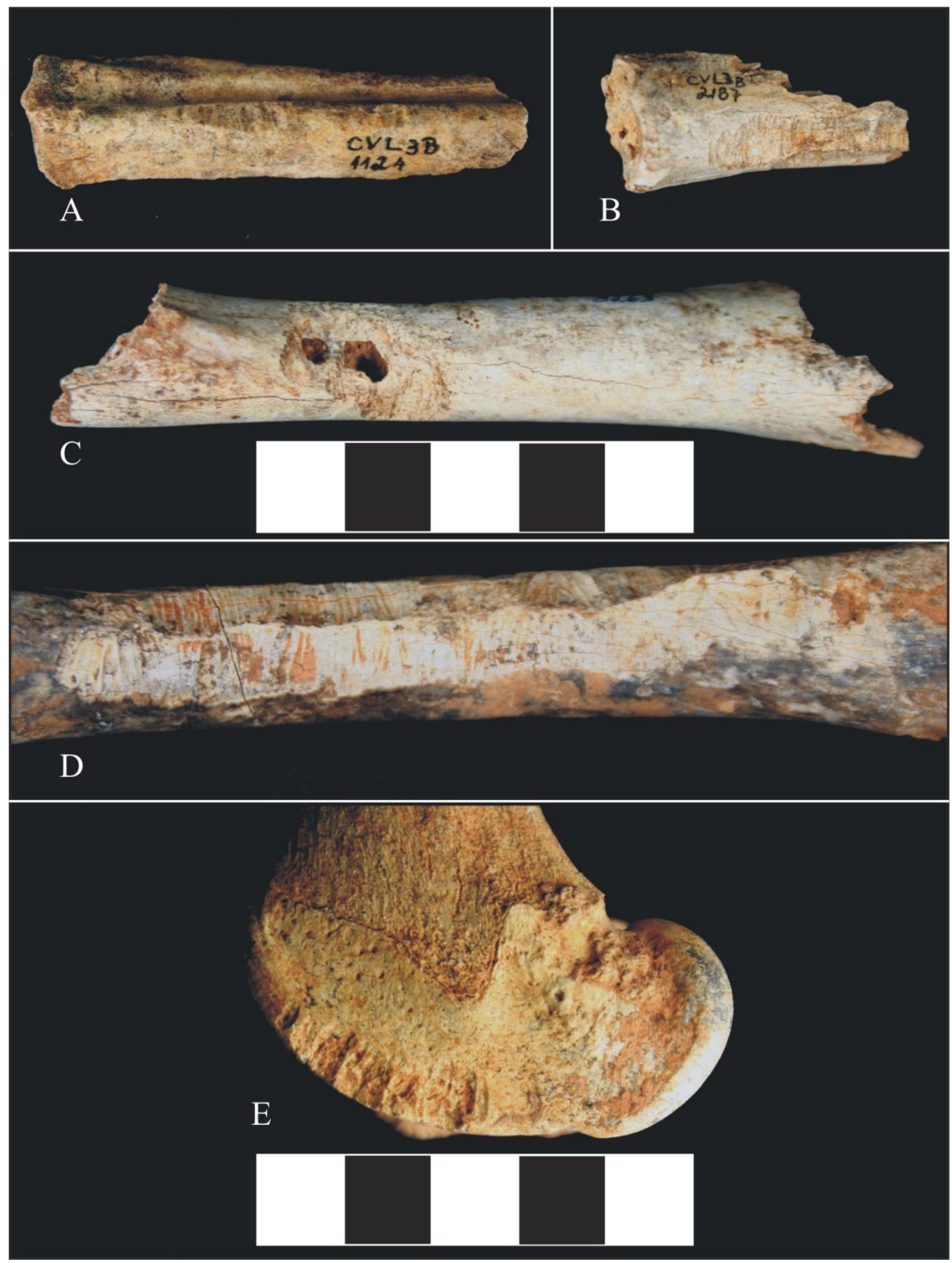

Figura 3.11 - Ossos que apresentam marcas produzidas por roedores. A e B metatarsos direitos de Cervidae, vistas anterior e lateral esquerda, respectivamente. $C$ - úmero esquerdo de Cervidae em vista posterior. D - fêmur direito de Cervidae em vista posterior da diáfise. E - fêmur direito de Tayassuidae em vista lateral esquerda da epífise distal. Todas as peças estão em mesma escala. 


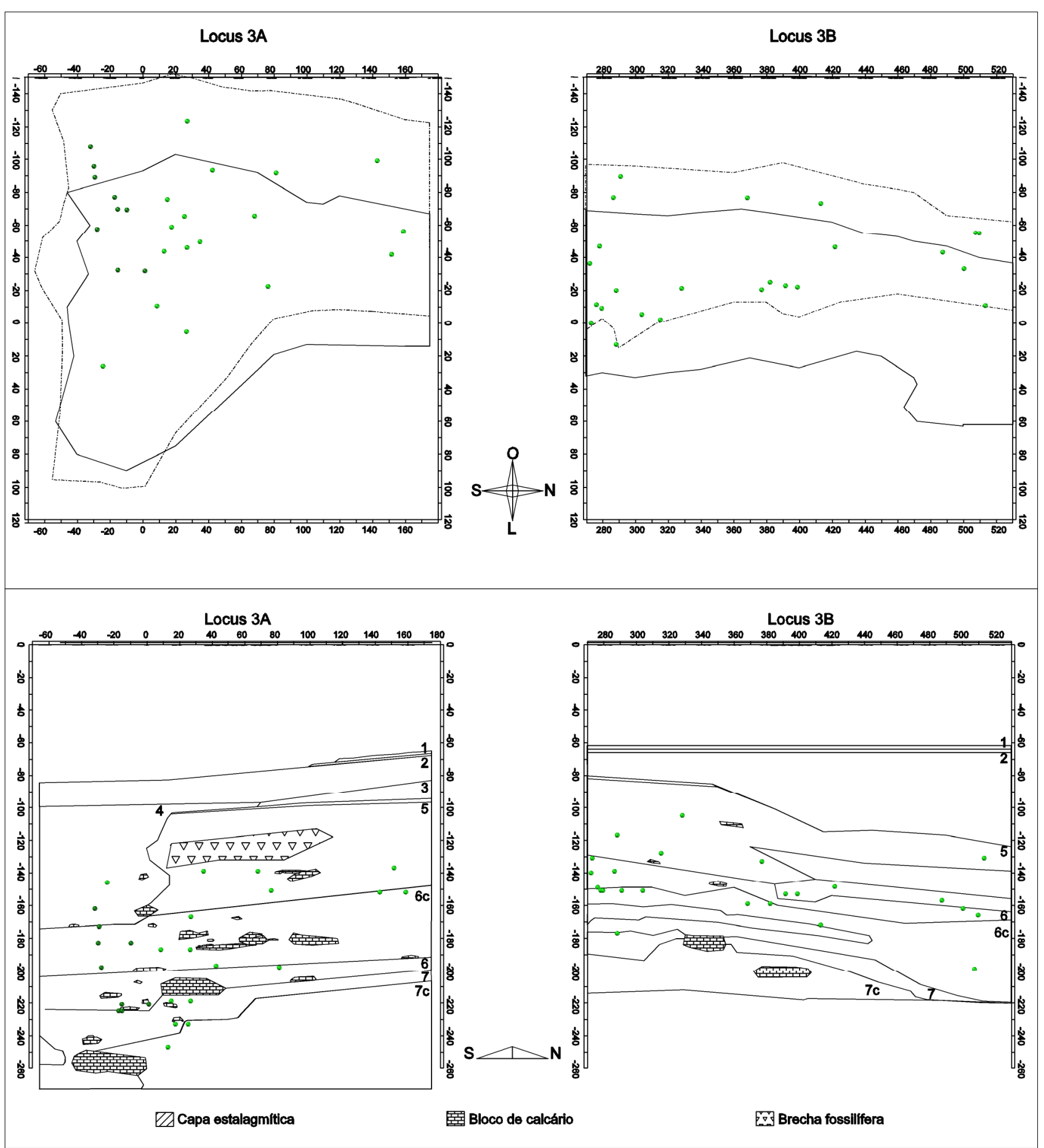

Figura 3.12 - Distribuição espacial dos ossos com marcas da ação de roedores. Acima vista de planta, abaixo vista leste. Cada esfera representa um espécime, sendo que as de coloração mais escura estão na região das bacias no sul do locus. Na vista de planta o contorno superior das paredes do locus está representado em linha contínua e o inferior em tracejada. 
central e norte; Figura 3.12).

$\mathrm{Na}$ vista leste do Locus 3A observa-se que uma pequena parte dos ossos roídos distribuem-se nas fácies 6 e 7 (Figura 3.12). As demais peças ocorrem nas fácies 4, 5 e 6 consolidada e de maneira bastante esparsa (Figura 3.12). No plano vertical do Locus 3B observa-se que as peças ocorrem na maior parte nas fácies 6 e 6 consolidada, com raras peças na fácies 5 (Figura 3.12).

\section{Modificações produzidas por animais: Carnívoros}

Foram identificadas, exclusivamente no Locus 3A, 24 ossos $(0,35 \%)$ apresentando alguns dos diferentes padrões descritos por Binford (1981) como sendo causados por carnívoros. Em alguns ossos observaram-se puncturas (Figura 3.13, A, D, K e L), que são definidas por Binford (1981; punctures) como feições em que determinada área de um osso sofre um colapso devido à pressão exercida pela dentição de um carnívoro. Em outros casos observou-se depressões (Figura 3.13, A, B, C e H), que segundo Binford (1981; pitting) ocorrem quando o tecido ósseo é forte o bastante para não colapsar sob o esforço das mordidas. Observaram-se também incisões (Figura 3.13, G e I), que decorrem, segundo Binford (1981; scoring), do ato de puxar ou rotacionar um osso entre os dentes. $O$ autor enfatiza que o padrão geral de consumo de ossos por carnívoros e necrófagos se inicia nos tecidos trabeculares e avança para os compactos, resultando na destruição preferencial de epífises. No entanto, durante a coleta de dados este padrão foi observado claramente em apenas uma peça (Figura 3.13, J). Apesar da minuciosa observação realizada, é possível que fatores como abrasão, fragmentação ou cobertura por 


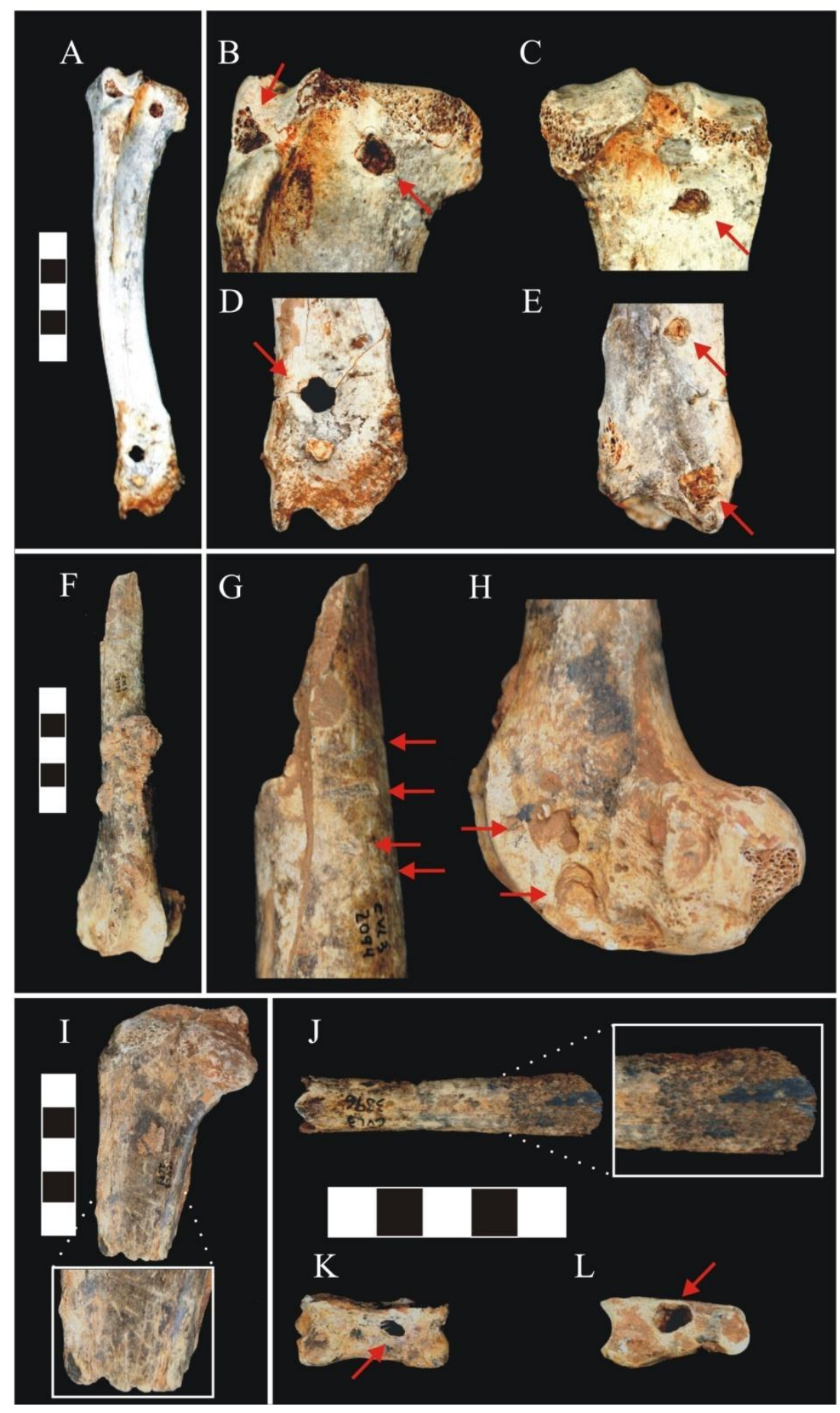

Figura 3.13 - Ossos que apresentam marcas produzidas por carnívoros. A - tíbia esquerda de Tayassuidae com puncturas e depressões ampliadas em B e D (porções proximal e distal anteriores, respectivamente) e em C e E (porções proximal e distal posteriores, respectivamente). $F$ - fêmur esquerdo de Tayassuidae com incisões e depressões ampliadas, respectivamente, em G e H. I - tíbia esquerda de Tayassuidae com incisões evidenciadas no detalhe. J metacarpo direito de Cervidae em que o tecido trabecular foi totalmente removido e o compacto apresenta muitas depressões sobrepostas na área proximal, como evidenciado no detalhe. $\mathrm{K}$ e $\mathrm{L}$ são falanges proximais de Tayassuidae que apresentam puncturas. As setas vermelhas indicam a localização de algumas das marcas observadas. 


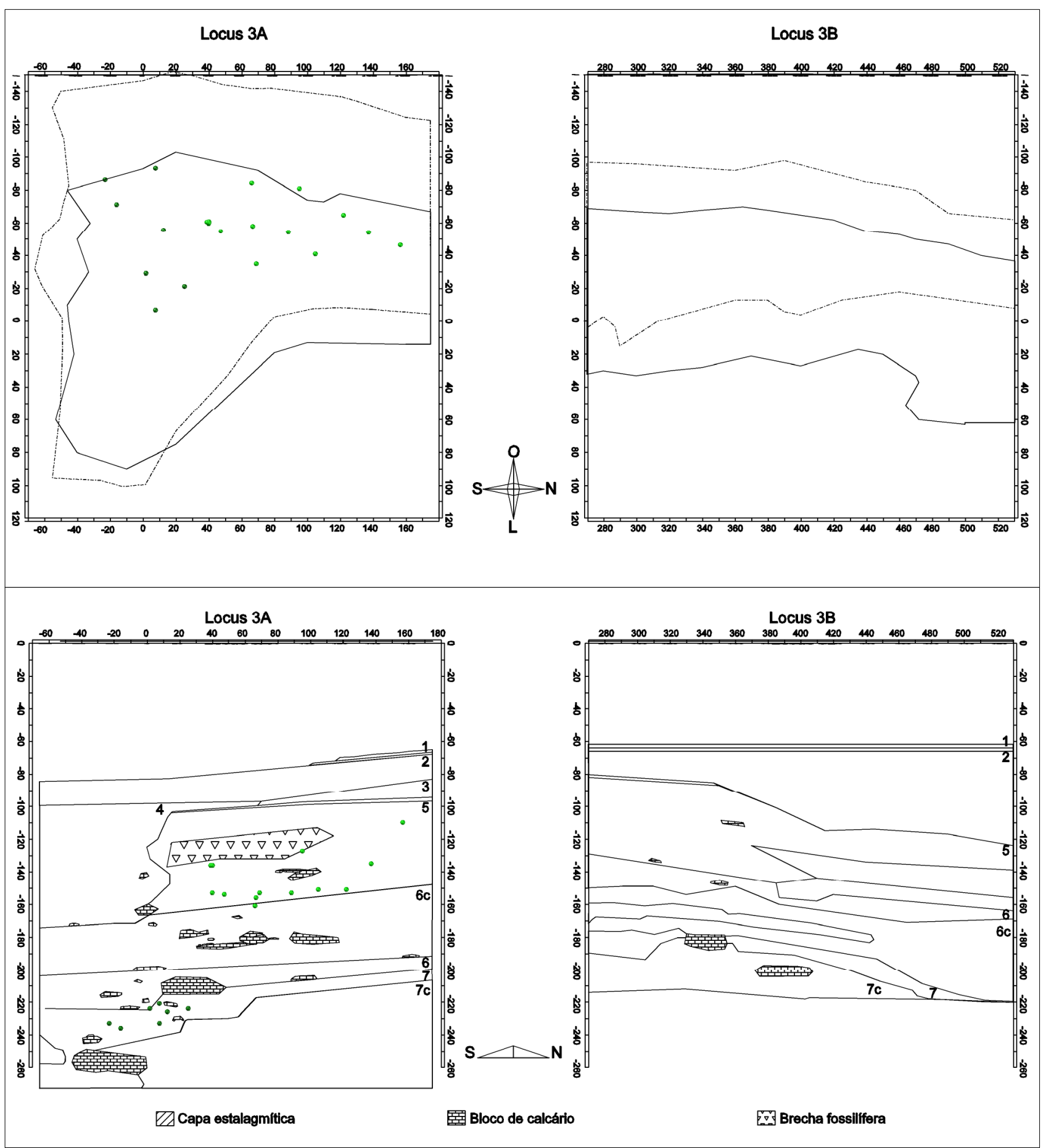

Figura 3.14 - Distribuição espacial dos ossos com marcas produzidas por carnívoros. Acima vista de planta abaixo, vista leste. Cada esfera representa um espécime, sendo que as de coloração mais escura estão na região das bacias no sul do locus. Na vista de planta o contorno superior das paredes do locus está representado em linha contínua e o inferior em tracejada. 
concreções, tenham obliterado marcas similares em outras peças.

Na Figura 3.14 é possível observar a distribuição das peças com marcas da ação de carnívoros. Na vista de planta do verifica-se que as peças se dispõe de maneira aproximadamente triangular na área central do Locus $3 \mathrm{~A}$ (Figura 3.14). No plano vertical constata-se que as peças do terço sul ocorrem na fácies 7 e que aquelas das áreas central e norte do locus ocorrem predominantemente na fácies 5 (Figura 3.14).

\section{Distribuição de peças complementares (remontagem)}

Na Figura 3.15 é possível observar a distribuição espacial das peças cuja complementaridade foi constatada. $\mathrm{Na}$ vista de planta do Locus $3 \mathrm{~A}$ verifica-se peças complementares distribuídas em ampla área desta subdivisão, com exceção das regiões sudeste e noroeste (Figura 3.15). Peças separadas por até $10,0 \mathrm{~cm}$ são as mais abundantes (18 ocorrências; 42,9\%), seguidas daquelas distanciadas por até $20,0 \mathrm{~cm}$ (10 ocorrências; 23,8\%). Distâncias até 30,0; 40,0; 50,0 e 60,0 cm são as menos abundantes, com 4, 0, 3 e 1 ocorrências, respectivamente $(9,5 \% ; 0 \% ; 7,1 \%$; e $2,4 \%$, respectivamente). O número de ocorrências com distanciamento superior aos $60,0 \mathrm{~cm}$ apresenta-se um pouco maior, totalizando 6 casos (14,3\%). Ainda na vista de planta observa-se que o movimento das peças complementares ocorre em diversos ângulos, sem uma orientação preferencial evidente (Figura 3.15).

No plano horizontal do Locus 3B as peças que se completam ocorrem por praticamente toda a área escavada, excetuando-se uma faixa longitudinal paralela e adjacente à face leste do locus (Figura 3.15). Peças distantes até 10,0 e 20,0 cm são as mais freqüentes (37,9\% e 41,4\%, respectivamente). Nas 

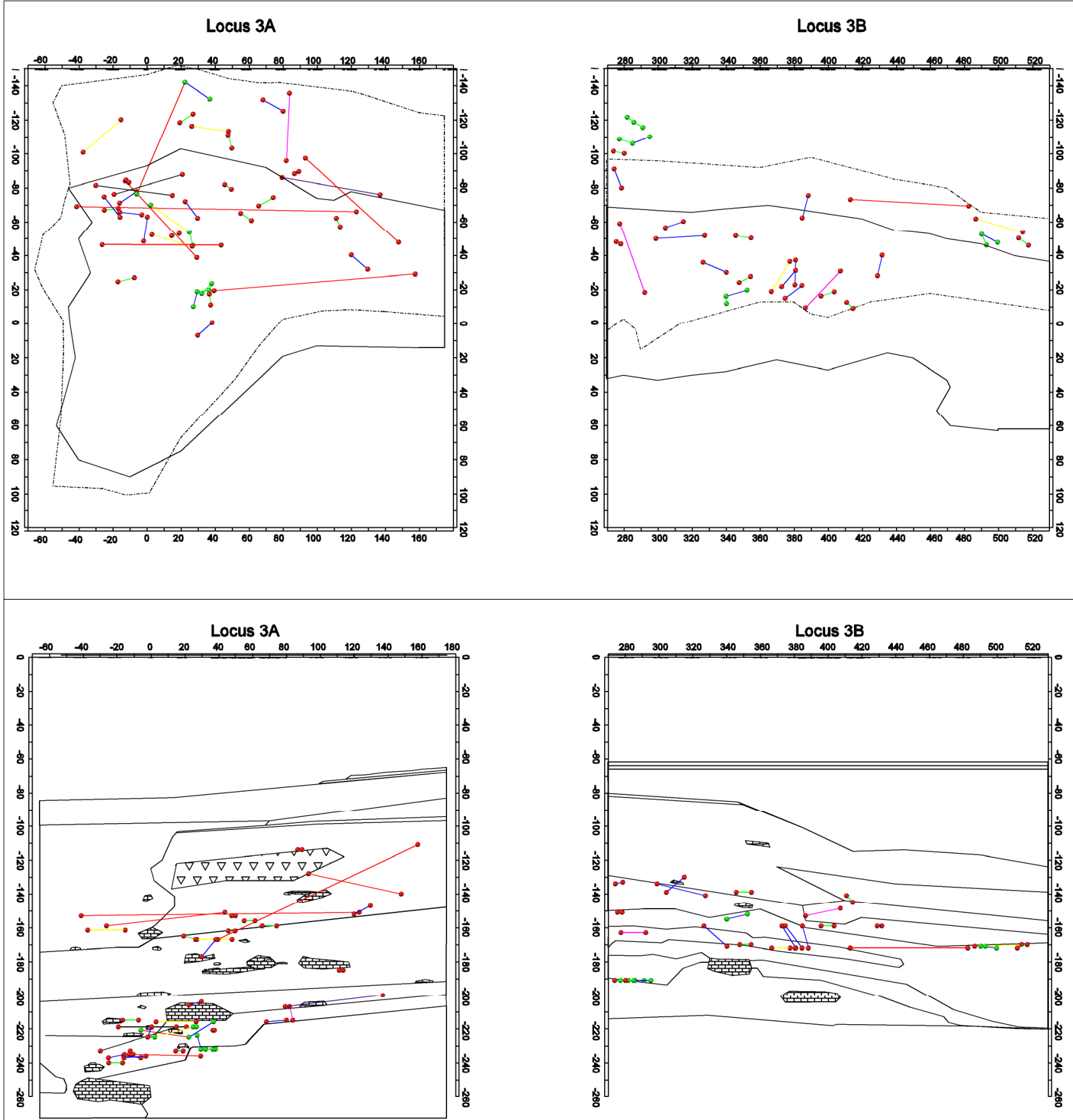

$\square$ Capa estalagmítica

臨 Bloco de calcário

国 Brecha fossilifera

Figura 3.15 - Distribuição espacial das peças complementares (remontagem). Acima vista de planta, abaixo vista leste. Cada esfera representa um espécime, sendo que as linhas unem as peças que se completam. A cor da linha indica a distância entre as peças segundo as categorias: verde até 10,0 cm; azul 10,1-20,0 cm; amarelo 20,1-30,0 cm; rosa 30,1-40,0 cm; preto 40,1-50,0 cm; roxo 50,1-60,0 $\mathrm{cm}$; vermelho mais de $60,0 \mathrm{~cm}$. As esferas verdes representam casos em que três ou mais espécimes se unem formando um mesmo elemento esquelético. Na vista de planta o contorno superior das paredes do locus está representado em linha contínua e o inferior em traceja 
categorias de distância com até 30,0; 40,0; 50,0 e 60,0 cm, além daquela com mais de 60,0 cm de deslocamento, as ocorrências são muito menos numerosas totalizando $10,3 \% ; 3,4 \% ; 3,4 \% ; 0 \%$ e 3,4\%; respectivamente. Como observado na vista de planta do Locus 3A o deslocamento das peças complementares ocorre em diversos ângulos, sem uma orientação preferencial evidente (Figura 3.15).

$\mathrm{Na}$ vista leste observa-se que algumas peças que se complementam estão inseridas numa mesma fácies, como se verifica nas fácies 4 e 5 , por exemplo (Figura 3.15). Em outros casos constata-se a situação oposta, com peças que se unem apesar de se localizarem em fácies diferentes, como entre as fácies 5 e 6 consolidada (Figura 3.15). Nesta figura observa-se também que a maioria das peças que se complementam estão mais distanciadas entre si no sentido horizontal do que vertical, de maneira que as linhas que as unem têm direções aproximadamente paralelas aos contatos entre fácies, como se verifica na parte norte do limite inferior da fácies 6 consolidada do Locus $3 A$, por exemplo (Figura 3.15). Verifica-se ainda na Figura 3.15 que algumas peças apresentam grande dispersão vertical em relação às respectivas partes complementares. Em alguns casos pode-se constatar que a diferença de profundidade entre uma peça e outra é maior do que a distância horizontal entre elas. Finalmente, observa-se na Figura 3.15 (esferas de cor verde) que em alguns casos três ou mais espécimes que se unem representam um mesmo elemento esquelético. Em parte deles a distribuição de cada espécime varia quanto à profundidade e fácies em que ocorre.

Abaixo segue a Tabela 3.1 onde constam os principais resultados obtidos com as análises realizadas neste capítulo. 
Tabela 3.1 - Principais resultados obtidos com as análise realizadas.

\begin{tabular}{|c|c|}
\hline Análise & Resultados \\
\hline $\begin{array}{l}\text { Distribuição } \\
\text { segundo o } \\
\text { grupo } \\
\text { taxonômico }\end{array}$ & $\begin{array}{l}\text { - Animais se distribuem em praticamente todas as fácies. } \\
\text { - } P \text {. onca ocorre exclusivamente no Locus } 3 \mathrm{~B} \text {. } \\
\text { - Mistura entre ossos de diferentes indivíduos. } \\
\text { - Um indivíduo de Cervidae na fácies } 2 \text { e um de } P \text {. onca nas fácies } 6 \\
\text { têm peças relativamente concentradas, ambos no Locus } 3 \mathrm{~B} \text {. }\end{array}$ \\
\hline $\begin{array}{l}\text { Distribuição de } \\
\text { peças } \\
\text { articuladas e } \\
\text { com lógica } \\
\text { anatômica } \\
\end{array}$ & $\begin{array}{l}\text { - Poucos grupos de ossos nestas condições. } \\
\text { - } 4 \text { dos } 5 \text { taxons identificados estão representados por ao menos um } \\
\text { grupo de ossos nestas condições. } \\
\text { - Grupos de ossos ocorrem isolados, mas distribuídos horizontal e } \\
\text { verticalmente pela área escavada Locus } 3 \text {. }\end{array}$ \\
\hline $\begin{array}{r}\text { Estad } \\
\text { fragme }\end{array}$ & $\begin{array}{l}\text { - Peças íntegras, fragmentadas e fragmentos somam } 16,7 ; 23,3 \text { e } \\
60,0 \% \text { da amostra, respectivamente. } \\
\text { - Percentuais semelhantes entre o Locus } 3 \mathrm{~A} \text { e B para partes } \\
\text { anatômicas íntegras e fragmentos, mas diferentes para peças } \\
\text { fragmentadas*. } \\
\text { - Presença dos três estados em todas as fácies fossilíferas com } \\
\text { fragmentos concentrados na metade sul da fácies } 5 \text { e } 6 \text { do Locus } 3 \mathrm{~B} \text {. }\end{array}$ \\
\hline $\begin{array}{l}\text { Expos } \\
\text { intemr } \\
\text { climá }\end{array}$ & $\begin{array}{l}\text { da amostra apresenta esta feição. } \\
\text { âo na intensidade da feição. } \\
\text { dispersão horizontal e vertical de peças com a feição pelo } \\
\text { 3. }\end{array}$ \\
\hline $\begin{array}{l}\text { Sinai } \\
\text { abra }\end{array}$ & $\begin{array}{l}\text { ção. } \\
\text { jeneralizada. }\end{array}$ \\
\hline $\begin{array}{r}\text { Modifice } \\
\text { produzid } \\
\text { roedo }\end{array}$ & $\begin{array}{l}\text { ão. } \\
\text { mente horizontal e verticalmente } \\
\text { e } 3 .\end{array}$ \\
\hline $\begin{array}{l}\text { Modific } \\
\text { produzic } \\
\text { carnív }\end{array}$ & $\begin{array}{l}\text { - } 0,35 \% \text { da amostra apresenta a feição. } \\
\text { - Peças modificadas ocorrem de maneira esparsa exclusivamente no } \\
\text { Locus } 3 \mathrm{~A} \text { e principalmente nas fácies } 5 \text { e } 7 \text {. } \\
\text { - } 0,35 \% \text { da amostra apresenta a feição. }\end{array}$ \\
\hline $\begin{array}{l}\text { Distribuição d } \\
\text { peças } \\
\text { complementar }\end{array}$ & $\begin{array}{l}\text { - No Locus 3A pequenas distâncias entre peças (até } 20,0 \mathrm{~cm} \text { ) } \\
\text { predominam }(66,7 \%) \text {. As distâncias médias (entre } 20,1 \text { e } 50,0 \mathrm{~cm} \text { ) e } \\
\text { grandes (mais de } 50 \mathrm{~cm} \text { ) são equivalentes, com 16,7\% cada. } \\
\text { - No Locus 3B pequenas distâncias entre peças (até } 20,0 \mathrm{~cm} \text { ) } \\
\text { predominam }(79,3 \% \text { ). As distâncias médias (entre } 30,0 \text { e } 50,0 \mathrm{~cm} \text { ) e } \\
\text { grandes (mais de } 50 \mathrm{~cm} \text { ) somam } 17,2 \text { e } 3,4 \% \text {, respectivamente. } \\
\text { - Não se observa orientação comum dos movimentos. } \\
\text { - Presença de movimentos intra-fácies e inter-fácies. } \\
\text { - Predominância de dispersão horizontal com movimentos paralelos } \\
\text { ao contato entre fácies. } \\
\text { - Presença de movimentos verticais consideráveis. } \\
\text { - Em alguns casos mais de dois espécimes formam o mesmo } \\
\text { elemento esquelético. }\end{array}$ \\
\hline
\end{tabular}

*Freqüências calculadas considerando Locus $3 \mathrm{~A}$ e B separadamente. 


\subsection{Discussão}

\section{Distribuição segundo o grupo taxonômico}

A distribuição espacial dos grupos taxonômicos analisados mostra que os restos ósseos destes animais ocorrem em praticamente todas as fácies do Locus 3. Uma vez que a deposição das fácies sedimentares parece ter ocorrido de forma lenta (como discutido adiante em exposição a intempéries climáticas e marcas produzidas por roedores), a distribuição generalizada dos fósseis em meio às fácies indica que a incorporação de ossos ao depósito do Locus 3 se deu ao longo de uma ampla faixa temporal. A natureza confinada do Locus 3 aliada a grande quantidade de espécimes fósseis resultou em uma alta densidade de peças, favorecendo a mistura horizontal e vertical dos ossos de diferentes indivíduos e taxons. Certamente uma gama de processos bióticos (e.g. pisoteio) e abióticos (e.g. compactação da coluna sedimentar) contribuiu para esta mistura, mas a influência de cada processo esteve invariavelmente subordinada a condições mais gerais, as quais estavam sujeitos todos os fósseis, que são o confinamento e o adensamento dos fósseis.

Considerando a complexidade observada na cronologia absoluta do Locus 3 e a mistura de ossos de diferentes táxons e de indivíduos do mesmo táxon é muito difícil atualmente definir uma cronologia relativa para a deposição dos animais. Desta forma, uma aproximação a que os resultados permitem chegar implica em basear a cronologia relativa nas peças articuladas e com lógica anatômica. Nesse caso, Cuniculus major, foi o primeiro táxon a ter seus restos incorporados ao depósito, na fácies 7 do Locus $3 \mathrm{~A}$ e na fácies 7 e 7 consolidada do Locus 3B. Em seguida, o único indivíduo de P. onca depositouse nas fácies 6 consolidada do Locus B. Seqüencialmente, restos de um 
indivíduo de Tayassuidae depositaram-se principalmente nas fácies 5 do Locus 3A, e em menor escala na fácies 4. Por fim, o animal mais recente do depósito certamente é o cervídeo cujos ossos ocorrem concentrados na fácies 2 do Locus 3B, relativamente isolados do restante dos fósseis.

Como visto nos resultados, alguns esqueletos mantiveram seus ossos relativamente agrupados, como o cervídeo na fácies 2 e a onça nas fácies 6 , ambos no Locus 3B. Isto revela que estes esqueletos, apesar de também estarem sujeitos ao confinamento e ao adensamento de peças, não foram influenciados intensamente por processos capazes de dispersar amplamente seus ossos, sobretudo, no primeiro caso. Isto mostra que, embora as condições de confinamento e adensamento em que os fósseis se encontravam no Locus 3 potencializaram as chances de mistura dos remanescentes ósseos, tais condições isoladamente não são as únicas responsáveis pelo padrão observado. Diante disso, a indagação sobre os outros fatores que contribuíram para a formação do depósito do Locus 3 fornece, por si própria, uma idéia da complexidade envolvida.

A distribuição espacial dos fósseis articulados e com lógica anatômica sugere uma complexidade ainda maior. Isto por que, após a queda no Locus 3 , a maioria dos indivíduos teve seus esqueletos totalmente desarticulados, dispersos e fragmentados, enquanto que em poucos casos isso aconteceu apenas parcialmente, preservando alguns ossos articulados ou com lógica anatômica. Sabe-se que o contexto ambiental no qual ocorre a necrólise de uma carcaça influencia outros processos bioestratinômicos como a sequência de desarticulação, dispersão e fragmentação de elementos esqueléticos (Hill, 1979; Holz e Simões, 2002). No caso do Locus 3 os principais contextos de 
necrólise que teriam favorecido a preservação de partes articuladas e com lógica anatômica são:

1) Soterramento rápido das carcaças; Segundo Holz e Simões (2002) quando o soterramento ocorre antes da necrólise total das partes moles existem grandes chances de preservação de esqueletos articulados praticamente inteiros.

2) Soterramento lento com dispersão e fragmentação moderadas; Este contexto de necrólise contribui para a preservação de apenas alguns segmentos articulados, sem seleção por parte anatômica e sujeitos às variações de intensidade nos processos dispersores e de fragmentação.

Com relação ao soterramento rápido, sabe-se que na região de Lagoa Santa a sedimentação em cavernas via fluxo de massa não tem um papel importante (Auler, 2009). Mais especificamente quanto à Gruta Cuvieri, tanto nos sedimentos escavados no Locus 3, quanto nas sondagens do conduto principal, não foram encontradas evidências de deslizamentos/fluxo de massa (Hubbe, 2008). Além disso, como será visto adiante, a distribuição espacial das peças com feições associadas ao intemperismo climático e com marcas de roedores sugerem que a sedimentação no interior do Locus 3 foi lenta. Estes mesmos resultados foram obtidos previamente para os ossos de megafauna recuperados do mesmo abismo (Hubbe, 2008). Com base nestes argumentos a ocorrência de soterramento rápido como fator de preservação de partes articuladas pode ser descartada.

Como visto, resta apenas uma possibilidade para a preservação dos 
ossos articulados e com lógica anatômica registrados no Locus 3. A considerável distribuição destes registros pelas diferentes regiões da área escavada, bem como o fato de eles representarem em sua maioria apenas partes dos esqueletos, favorece a aceitação de que a sedimentação lenta associada à ação moderada de processos de dispersão e fragmentação destes restos seja responsável pelo padrão observado. Uma informação que reforça esta interpretação é a de que os grupos de ossos articulados e com lógica anatômica são formados por peças íntegras, fragmentadas e fragmentos (Figuras 3.4 e 3.6), o que sugere que os processos de necrólise, desarticulação, dispersão e fragmentação ocorreram mais ou menos simultaneamente e em intensidades variáveis. Um caso que chama a atenção pela contribuição de um fator adicional na preservação da articulação/lógica anatômica é o dos restos do taiassuídeo localizado na área central do Locus 3A. Além de este esqueleto reunir espécimes nos três estados de fragmentação, sugerindo a ação moderada e concomitante dos processos mencionados, ele ocorre a aproximadamente $20 \mathrm{~cm}$ abaixo de uma brecha de ossos. Esta brecha muito provavelmente serviu de anteparo para a ação de processos ocorridos posteriormente, como o pisoteio e a queda de blocos, protegendo os restos deste taiassuídeo. Situação semelhante foi encontrada por Hubbe (2008) e Kos (2003a), sendo que estes autores encontraram peças íntegras protegidas por uma brecha de ossos e uma capa estalagmítica, respectivamente.

\section{Estado de fragmentação}

Os resultados sobre o estado de fragmentação mostram que as 
subdivisões do Locus 3 apresentam percentuais diferentes de peças íntegras, fragmentadas e fragmentos. $O$ Locus $3 \mathrm{~A}$ apresenta freqüências maiores para as duas primeiras categorias e o Locus 3B apresenta freqüência maior para a terceira. Para o Locus 3A os fatores de fragmentação são a queda de animais, o pisoteio, a maior quantidade de blocos abatidos e a compactação da coluna sedimentar. Já para o Locus 3B os fatores de fragmentação consistem em pisoteio, menor quantidade de blocos abatidos e a compactação da coluna sedimentar. Desta forma, como o Locus 3A apresenta fatores mais favoráveis à de fragmentação do material ali depositado do que o Locus 3B, seria esperado encontrar mais fragmentos no primeiro. No entanto, os resultados obtidos são contrários a isto.

A discussão dos resultados sobre os estados de fragmentação é bastante problemática principalmente por dois motivos: 1) boa parte das fácies escavadas no Locus 3B eram consolidadas, ocasionando a fragmentação de vários dos espécimes plotados durante as escavações, e 2) entre todo o material de peneira recuperado nas escavações das duas áreas do Locus 3 foram numerados e analisados apenas aqueles minimamente passíveis de identificação anatômica, restando nas peneiras centenas de fragmentos que não podem ser identificados. Desta forma, a maior abundância de fragmentos no Locus 3B observada nos resultados pode ser produto de um viés resultante destes dois motivos. Aparentemente a solução deste problema não se dará de maneira trivial, mas alguns esclarecimentos podem ser obtidos com trabalhos futuros que avaliem sistematicamente os tipos de fragmentação do material do Locus 3 e que contabilizem os fragmentos não identificáveis anatômica/taxonomicamente que foram recuperados na peneira de cada 
exposição.

Os resultados obtidos com a análise do estado de fragmentação em função das partes anatômicas revelam que o Locus $3 \mathrm{~A}$ e B apresentam percentuais semelhantes com relação a peças íntegras e fragmentos e valores diferentes para peças fragmentadas. O Locus 3A apresenta, principalmente, maior percentual de peças fragmentadas que são relativamente grandes e frágeis (vértebras, costelas, escápulas e pélvis). Já o Locus 3B apresenta maiores freqüências de peças fragmentadas que são relativamente pequenas e resistentes (dentes, ossículos do carpo/tarso e falanges). Os fatores que levaram a esta fragmentação diferencial em função das partes anatômicas também são difíceis de avaliar, principalmente devido ao primeiro motivo relatado acima (fragmentação durante a escavação).

A grande quantidade de peças do Locus 3B, como dentes, ossículos do carpo/tarso e falanges, que apresentavam fragmentação recente causada durante a escavação chamou a atenção ainda durante a coleta de dados. Como a detecção deste problema só ocorreu após o término da coleta de dados do material do Locus $3 \mathrm{~A}$, a presença desta característica não foi registrada sistematicamente. No entanto, de acordo com a observação realizada durante a coleta de dados a fragmentação recente certamente é mais freqüente nas peças do Locus 3B. Por isso, a fragmentação diferencial das partes anatômicas entre as duas subdivisões do Locus 3 provavelmente resulta de um viés criado durante as escavações.

Apesar dos problemas discutidos, os resultados sobre os estados de fragmentação revelam informações importantes sobre a formação do depósito do Locus 3. A mais evidente é que peças nos três estados de fragmentação 
ocorrem em todas as fácies e outra é que predominam os fatores de fragmentação de natureza bioestratinômica (queda, pisoteio, abatimento de blocos) em relação aos diagenéticos (compactação da coluna sedimentar). Desta forma, entre os diferentes fatores de fragmentação que agiram sobre os restos ósseos do Locus 3, o pisoteio por parte de outros animais parece ter sido aquele que o fez de maneira mais intensa, seguido da queda de animais e de blocos calcários. Isto por que o pisoteio teve uma grande abrangência espacial, incluindo tanto o Locus $3 \mathrm{~A}$ quanto o 3B. Outro ponto importante é que embora nem todos os animais que caíram no Locus 3 sobreviveram à queda, aqueles que o fizeram provavelmente pisotearam intensamente tanto os ossos em superfície, quanto aqueles em sub-superfície. Além disso, uma vez que os eventos de pisoteio decorrem do fato de os animais sobreviverem à queda no Locus 3, eles muito provavelmente ocorreram em diferentes momentos ao longo da formação do depósito fossilífero.

Os demais fatores de fragmentação, muito provavelmente, tiveram uma ação mais restrita. A queda de animais e a maioria dos blocos abatidos limitaram-se espacialmente às regiões central e sul do Locus $3 \mathrm{~A}$, atingindo ossos em superfície e sub-superfície. Como argumentado para o pisoteio, estes fatores provavelmente também agiram em diferentes momentos ao longo da formação do depósito fossilífero. No entanto, o abatimento de blocos ocorreu principalmente durante a deposição das fácies 6,6 consolidada e 7 . Já a compactação da coluna sedimentar parece ser o fator que menos contribuiu para a fragmentação do material ósseo, pois provavelmente limitou-se espacialmente aos níveis mais profundos do pacote fossilífero, só exercendo alguma influência sobre os ossos após o acúmulo de considerável volume de 
sedimentos. Por isso, este fator de fragmentação provavelmente não agiu durante boa parte da formação do depósito do Locus 3.

À luz destas informações fica claro que os esqueletos dos animais incorporados ao Locus 3 sofreram fragmentação durante várias etapas de seu histórico tafonômico, desde a necrólise até após o soterramento final. Entre os fatores de fragmentação identificados o pisoteio é o principal, seguido da queda de animais e blocos calcários, enquanto que a compactação da coluna sedimentar é o que teve menor influência sobre os ossos. Fica evidente também a ausência de níveis com peças de um estado de fragmentação específico, demonstrando que os fatores de fragmentação agiram sobre cada espécime independentemente, causando fragmentação de alguns deles em diferentes graus e mantendo outros íntegros, apesar da íntima associação espacial entre eles. Este cenário ilustra bem a complexidade intrínseca à formação do pacote fossilífero do Locus 3, tanto pela diversidade de processos envolvidos, quanto pela concomitância com que eles aparentemente agiram sobre os ossos.

Comparativamente ao que Hubbe (2008) observou no material de megafauna do Locus 3 os resultados discutidos aqui são bastante similares. Primeiramente, por que o percentual de peças fragmentadas e de fragmentos verificado aqui $(83,3 \%)$ é bastante próximo ao que Hubbe (2008) averiguou no material de megamamíferos $(84,2 \%$;). Tal constatação contraria a expectativa de que os restos de mamíferos de médio porte, por apresentarem ossos menores em relação à megafauna, reuniriam um maior percentual de peças fragmentadas e de fragmentos. No entanto, considero importante reiterar que parte do material ósseo das peneiras do Locus 3 não foi considerada neste 
trabalho por não ser passível de identificação taxonômica. Desta forma, é provável que entre 0 material de peneira existam fragmentos de mesomamíferos que não foram considerados aqui, o que potencialmente acarreta em resultados enviesados.

Outro ponto em comum com o trabalho de Hubbe (2008) é que este autor identificou o pisoteio como o agente mais importante na fragmentação dos ossos da megafauna, com pouca ação do abatimento de blocos, que se restringiu à fácies 6 . Além disso, Hubbe (2008) também observou a associação espacial entre restos da megafauna em diferentes estados de fragmentação, concluindo que os fatores responsáveis pelo padrão agiram sobre os espécimes individualmente.

Como visto, no que se refere à fragmentação os restos dos mamíferos de médio e grande porte do Locus 3 apresentam históricos tafonômicos bastante semelhantes.

\section{Exposição a intempéries climáticas}

Conforme visto nos resultados, as peças com feições associadas ao intemperismo climático somam $21,7 \%$ da amostra. A ampla dispersão horizontal e vertical destas peças sugere que: 1) elas permaneceram expostas em superfície em diferentes momentos da formação do pacote fossilífero; 2) isso ocorreu principalmente em um determinado momento e mais tarde as peças foram retrabalhadas assumindo a distribuição observada ou; 3 ) tanto a exposição, quanto a re-exposição em superfície durante diferentes momentos da formação do pacote fossilifero possibilitaram a ação do intemperismo (considerando que as peças re-expostas são aquelas que já haviam sido 
soterradas previamente e que tornaram a ter suas superfícies evidenciadas, total ou parcialmente, na interface ar/sedimento).

A esporadicidade com que os animais caíram no Locus 3 favorece a aceitação da primeira alternativa. No entanto, os resultados sobre as peças com sinais de abrasão, discutidos a seguir, sugerem re-exposição de ossos à interface ar-sedimento. Portanto, apesar de a exposição dos espécimes em superfície provavelmente ser o principal contexto em que o intemperismo agiu, uma parcela dos ossos deve ter sido intemperizada após ser re-exposta. Desta forma, a alternativa 1 pode ser descartada.

A alternativa 2, por seu turno, exige a ocorrência de um grande evento de retrabalhamento capaz de distribuir as peças intemperizadas de um dado nível por todas as fácies do Locus 3. Porém, a presença de esqueletos com ossos articulados e com lógica anatômica, identificados aqui e em Hubbe (2008), e o fato de eles se distribuírem amplamente pelas fácies do Locus 3 representam uma forte evidência contrária a ocorrência de eventos de retrabalhamento de grande magnitude. Outra evidência que se opõe à idéia de um grande evento de retrabalhamento no Locus 3 advém da análise dos sedimentos. Embora Haddad-Martim (2007) tenha encontrado indícios de alterações pós-deposicionais nos sedimentos escavados, eles se relacionam com movimentos que geram vazios no interior das fácies, indicando alterações de sub-superfície e efeitos de contração, mas não a ocorrência de um evento de retrabalhamento de alta energia. Diante destes dois argumentos, esta hipótese pode ser considerada inviável.

Com relação à alternativa 3, que combina exposição em superfície e reexposição à interface ar/sedimento, existem evidências bastante claras. Como 
discutido anteriormente, não há indícios de soterramento rápido de animais no Locus 3. Isto sugere que parte dos ossos depositados em cada fácies foi soterrada lentamente, permanecendo em exposição na superfície durante períodos relativamente longos. Soma-se a isso o fato de, como discutido a seguir, existirem indícios da existência de um mecanismo de re-exposição de peças à interface ar/sedimento. Desta forma, a exposição em superfície e a reexposição de peças à interface ar/sedimento podem ser consideradas responsáveis pelo padrão de distribuição espacial observado para as peças intemperizadas, sendo que entre elas a primeira parece ter sido preponderante, enquanto a outra teve um papel secundário.

Assim como se observou para a fragmentação, os resultados sobre a ação do intemperismo discutidos no presente e aqueles obtidos por Hubbe (2008) são muito semelhantes. Em ambos os trabalhos os percentuais de peças intemperizadas representam de pouco mais de $20 \%$ das respectivas amostras, mais especificamente, $25,8 \%$ para a megafauna (Hubbe, 2008) e $21,7 \%$ verificados aqui. O outro ponto concordante com o trabalho de Hubbe (2008) é que a sedimentação no Locus 3 parece ter sido lenta, contribuindo para que os restos ósseos ficassem expostos em superfície e, consequentemente, ao intemperismo climático.

\section{Sinais de abrasão}

As peças que apresentam esta modificação da superfície óssea totalizam $9 \%$ da amostra. Considerando que a principal forma de acumulação óssea no Locus 3 se deu pela queda de animais neste abismo (Mayer, 2007; Hubbe, 2008), assume-se que os processos subseqüentes, incluindo a 
abrasão, ocorreram exclusivamente in situ. Durante a coleta de dados sobre abrasão observou-se espécimes modificados de maneira generalizada, o que segundo Trueman e Benton (1997) tem sido associado ao transporte do material por longas distâncias. Por outro lado, Fernandez-Jalvo e Andrews (2003) afirmam que tal associação não é válida, tanto pela dificuldade de reproduzir situações realísticas em experimentos de abrasão, quanto porque os ossos podem ser abrasonados sem terem sido transportados. No caso do Locus 3 , com sua natureza confinada, as peças que apresentam abrasão generalizada potencialmente foram movidas, mas necessariamente, em seu interior.

Assim como discutido anteriormente sobre a ação do intemperismo, não há indícios de que os sinais de abrasão foram gerados simultaneamente em vários espécimes de um mesmo nível estratigráfico, e mais tarde, um grande evento de retrabalhamento os dispersou pelo Locus 3. Por isso, considera-se que a abrasão das peças tenha ocorrido paulatinamente ao longo da formação do depósito fossilífero. Segundo esta interpretação, o processo de abrasão dos fósseis ocorreu, mais provavelmente, por duas vias: 1) na superfície, com energia fornecida principalmente pela água; e 2) no interior das fácies; por atrito principalmente com as partículas sedimentares.

Convém esclarecer que a abrasão na superfície inclui também aquelas peças que estiveram soterradas em níveis estratigráficos relativamente superficiais e que posteriormente foram total ou parcialmente re-expostas à interface ar/sedimento. Uma vez que o Locus 3 apresenta sedimentos com alterações pós-deposicionais decorrentes da ação da água, o mecanismo responsável por esta re-exposição de espécimes muito provavelmente 
relaciona-se diretamente com o regime hídrico. Isto por que nas áreas do locus em que a ação de fluxos superficiais, gotejamentos e poças foi mais intensa ou recorrente a matriz sedimentar acabou por ser localmente erodida, o que potencialmente propiciou que os ossos da subsuperfície fossem pouco a pouco re-expostos em superfície.

Entre as alternativas mencionadas a abrasão na interface ar/sedimento parece ser a principal responsável pelo padrão observado. Primeiramente, por que sua fonte de energia advém da atividade hídrica, que é relativamente regular conforme os ciclos sazonais, e muitas ordens de grandeza mais dinâmica do que os movimentos de partículas numa coluna sedimentar. Segundo, por que a ação da água na interface ar/sedimento promove o atrito entre uma maior variedade de elementos, como sedimentos e ossos e entre ossos e outros ossos. Outro aspecto desta interpretação que condiz com os resultados obtidos é que a superfície das peças sujeitas ao atrito pode ser afetada tanto de forma generalizada, quanto localizada, sendo o último caso provavelmente mais comum em peças parcialmente soterradas. Em alguns casos, dependendo da intensidade de incidência de água, bem como das propriedades físicas dos espécimes fósseis, a re-exposição em superfície pode ter implicado não apenas na abrasão, mas também na movimentação destas peças.

Já a segunda possibilidade de abrasão dos fósseis, que ocorre exclusivamente no interior das fácies, parece ter uma participação menos acentuada do que a discutida anteriormente. Embora Haddad-Martim (2007) relate a ocorrência de movimentos dos sedimentos do Locus 3, decorrentes de alterações em sub-superfície e efeitos de contração, a abrasão resultante deste 
processo parece ter sido tênue. Esta afirmação é embasada principalmente no argumento de que embora se saiba que depósitos sedimentares, no caso o pacote fóssilífero, não são estáticos (Andrews, 2006), a energia resultante da movimentação das partículas sedimentares no interior do Locus 3 pode, em geral, ser considerada muito pequena. É possível que outros processos, como o pisoteio, eventualmente contribuam de maneira indireta com um pouco mais de energia para a abrasão no interior das fácies, intensificando momentaneamente $\mathrm{o}$ atrito entre os sedimentos e os restos fósseis. No entanto, mesmo com esta intensificação da abrasão no interior das fácies, considero que este mecanismo tenha contribuído em menor escala do que o discutido anteriormente.

Desta forma, a abrasão na interface ar/sedimento, em oposição a aquela restrita ao interior das fácies, caracteriza-se como a principal via responsável pelos sinais de abrasão observados no material estudado. Este processo mostra-se importante também para ao retrabalhamento dos fósseis, promovendo a re-exposição e movimentação de espécimes que já haviam sido soterrados, sujeitando-os tanto a ação da abrasão, quanto de outros fatores.

Como se verificou para a fragmentação e o intemperismo, os resultados relativos à abrasão obtidos aqui e em Hubbe (2008) também são semelhantes. O percentual de peças abrasonadas verificado por Hubbe (2008; 8,6\%) para restos da megafauna do Locus 3 é muito próximo daquele encontrado no presente (9\%). A principal diferença em relação ao material estudado aqui é que para a megafauna não se registraram ossos com abrasão generalizada (Hubbe, 2008). Com base nesta informação Hubbe (2008) descartou a possibilidade da ocorrência de fluxos hídricos correntes e contínuos no Locus 
3. Apesar de entre os ossos estudados aqui alguns apresentarem abrasão generalizada, a interpretação de Hubbe (2008) mantém-se coerente. Primeiramente, por que de maneira geral, tais peças são consideravelmente menores do que aquelas da megafauna, sendo mais facilmente impelidas pela água, principal elemento motriz da abrasão. Em segundo lugar, por que parte dos esqueletos de mamíferos de médio porte está depositada no Locus 3 desde considerável tempo antes de o primeiro megamamífero acidentar-se ali (os restos da megafauna ocorriam principalmente na metade superior do pacote fossilífero; ver Figura 2.3; Capítulo 2 - Cura e identificação do material). Sendo assim, uma grande parte dos restos de mesomamíferos do Locus 3 esteve sujeita à abrasão por um período maior do que os da megafauna, apresentando como conseqüência peças mais intensamente alteradas pelo processo.

\section{Modificações produzidas por animais: Roedores}

Segundo as marcas deixadas por roedores nos ossos exumados do Locus 3 estes animais modificaram a superfície de uma parcela muito pequena do total $(1,10 \%)$. As marcas da ação de roedores nos ossos sugerem que eles permaneceram expostos na superfície e que provavelmente foram movimentados. Isto por que, segundo o trabalho experimental de Hoffman e Hays, (1986), roedores são importantes agentes que transportam ossos, sobretudo, aqueles de pequenas dimensões, como os ossos fragmentados e os fragmentos do Locus 3. Como as peças modificadas por roedores se distribuem de maneira ampla horizontal e verticalmente pelo Locus 3, exceto 
nas fácies em que os ossos são escassos (fácies 1, 2 e 3), estes animais provavelmente modificaram e/ou transportaram as peças em diferentes momentos da formação do depósito fossilífero.

Neste caso, existem três possibilidades pelas quais a ação de roedores poderia ser explicada: 1) os roedores acessaram o interior do Locus 3 através da fissura entre o Locus 3B e C; 2) os roedores acessaram o interior do Locus 3 descendo pelas paredes do locus; e 3) os roedores caíram pela entrada do Locus $3 \mathrm{~A}$, sobreviveram à queda, e modificaram alguns ossos que ali jaziam.

A identificação de qual via permitiu o acesso dos roedores ao material fóssil do Locus 3, ou mesmo qual delas foi a mais importante, é difícil de determinar, representando um problema de equifinalidade. Assim, restam apenas algumas considerações a fazer sobre cada uma delas.

Com relação à primeira hipótese, convém esclarecer que a fissura que interliga os Loci 3B e 3C é bastante estreita (Figura 1.2; Capítulo 1 Introdução), mas não o suficiente para impedir a passagem de pequenos roedores. Outro ponto importante é que em algum momento esta passagem foi obstruída pelo abatimento de blocos. Desta forma, como os ossos com marcas de roedores ocorrem amplamente pelo pacote fossilífero, a entrada destes animais não pode ter ocorrido exclusivamente pelo Locus 3C.

Quanto à segunda possibilidade, deve-se considerar que alguns roedores nativos que habitam cavernas e abrigos rochosos (e.g. Kerodon rupestris, Wied, 1820; Mares e Lacher Jr., 1987; Santana et al., 2003) apresentam anatomia especializada para a escalada, o que Ihes permitiria acessar o interior do Locus 3. Embora suas paredes sejam verticais, elas são consideravelmente irregulares, apresentando muitas reentrâncias e projeções, 
tanto da própria rocha calcária na qual se formou a caverna, quanto de espeleotemas e brechas agregadas a ela. Assim, não é possível descartar a hipótese de que roedores adaptados a ambientes cavernícolas acessaram o material estudado alterando-o ou movendo-o.

Em concordância com a terceira possibilidade, os ossos roídos no interior do Lócus 3 decorrem da ação de animais que eventualmente caíram ali e sobreviveram algum tempo após a queda. Neste caso, considerando os dados do presente trabalho e aqueles em Mayer (2007) a identificação de quatro grupos de roedores (Cuniculidae, Dasyproctidae, Muridae e Caviidae) que somam pelo menos 37 indivíduos, fornece algum subsidio para esta hipótese, mas não exclui as anteriores.

Como mencionado, com base nas evidências disponíveis até o momento é difícil identificar se cada possibilidade elencada contribuiu para o padrão observado e qual seu peso no processo. Além disso, as diferentes vias de acesso dos roedores podem ter contribuído concomitantemente para a modificação e o transporte de ossos depositados no Lócus 3. Em relação a esta questão, os restos de megafauna não oferecem informações adicionais, pois não foram encontradas marcas de roedores neste material (Hubbe, comunicação pessoal, 2011).

\section{Modificações produzidas por animais: Carnívoros}

Conforme os resultados sobre peças que apresentam marcas da ação de carnívoros elas representam uma parcela muito pequena do total $(0,35 \%)$. Estas peças ocorrem de maneira esparsa exclusivamente no Locus $3 \mathrm{~A}$ e principalmente nas fácies 5 e 7 o que indica um intervalo entre dois momentos 
da ação destes animais.

O trabalho de Hubbe (2008), desenvolvido previamente com o material de megafauna do Locus 3, identificou a presença de marcas de carnívoros em apenas um osso de Tapirus terrestris entre os 1197 analisados no total $(1 / 1197=0,0008)$. Hubbe $(2008)$ concluiu que a ação de carnívoros foi efêmera, não contribuindo expressivamente para o acúmulo de ossos no Locus 3 . No presente estudo, 14 dos ossos com marcas de carnivoros são de Tayassuidae, 3 de Cuniculus paca, 3 de Cuniculus major e 1 de Cervidae. Considerando estes 21 ossos frente as 6140 peças analisadas no total, os resultados deste trabalho estão de acordo com aqueles obtidos por Hubbe (2008), mas mostram, ainda que muito modestamente, uma participação maior dos carnívoros na modificação da superfície dos ossos de mesomamíferos do que da megafauna $(21 / 6140=0,003)$.

É importante lembrar que, como enfatizado por Lyman (1994a), a identificação de marcas produzidas por estes animais não necessariamente implica que eles foram os agentes acumuladores dos ossos. Além disso, nas sondagens realizadas no abrigo da caverna e ao longo do conduto principal (Figura 1.2; Capítulo 1 - Introdução) não há indícios do uso destas áreas por carnívoros. Desta forma, outra possibilidade é que os animais responsáveis pelas marcas observadas no material do Locus 3 tenham acessado o interior do fosso. Como mencionado anteriormente, a fissura que comunica o Locus 3B com o 3C é bastante estreita (Figura 1.2; Capítulo 1 - Introdução) para permitir a entrada de animais de médio porte e sua ligação com o exterior obstruiu-se em algum momento no passado, os carnívoros que alteraram os ossos devem ter caído no abismo. Neste caso, os animais responsáveis pelas marcas 
observadas devem estar entre os pequenos mamíferos do Locus 3, pois como pode ser visto nas Figuras 3.3 e 3.14 o indivíduo de $P$. onca exumada do Locus 3B não apresenta a menor associação estratigráfica com as peças modificadas. Os pequenos mamíferos do Locus 3 foram analisados apenas parcialmente até o momento, sendo que a identificação taxonômica destes animais foi realizada somente para o material do Locus $3 \mathrm{~A}$, e entre eles sabese que estão representados ao menos dois indivíduos de carnívoros de pequeno porte (Mayer, 2007).

Alguns trabalhos (White et al., 1984; Behrensmeyer et al., 1992; Wang e Martin, 1993) têm relatado que odores de carcaças e ruídos de animais aprisionados no interior de abismos parecem exercer alguma atratividade sobre necrófagos e carnívoros. Existem também relatos de animais que sobreviveram a quedas maiores do que a profundidade do Locus 3 (Wang e Martin, 1993; Kos, 2003b; Ostbye et al., 2006). Se isso ocorreu, seria esperado encontrar, somente no Locus 3, poucos ossos com marcas destes animais, como foi observado. No entanto, avalio que para esta hipótese ser aceita são necessárias informações mais consistentes sobre os fatores que contribuem para o aprisionamento de carnívoros em abismos. Além disso, estudos futuros que identifiquem o restante do material de pequenos mamíferos do Locus 3A e que avaliem a compatibilidade entre os táxons carnívoros registrados e as marcas observadas nos ossos terão papel importante no esclarecimento desta questão.

\section{Distribuição de peças complementares (remontagem)}

A distribuição espacial das peças complementares no Locus $3 A$ e $B$ 
demonstra que as pequenas distâncias entre peças (até $20,0 \mathrm{~cm}$ ) predominam e que distâncias médias (entre 20,1 e 50,0 cm) e grandes (mais de 50,1 cm) são menos freqüentes.

Vários fatores estão envolvidos tanto na fragmentação das peças quanto em sua movimentação, de maneira que a causa de cada um destes processos pode ser diferente. Como os principais fatores de fragmentação atuantes no Locus 3 são o pisoteio, a queda de animais e de blocos calcários, e eles potencialmente implicam em movimentação das peças recém fragmentadas, tais fatores provavelmente também representam o mais importante mecanismo de fragmentação e dispersão de peças complementares. Embora outros fatores como a ação de roedores e carnívoros devam ter contribuído na fragmentação e dispersão das peças, as evidências sobre as respectivas participações na formação do depósito são, em geral, pouco expressivas.

A discussão dos resultados sobre as distâncias entre peças remontadas e a orientação dos movimentos é muito difícil, sobretudo, pela multiplicidade de fatores potencialmente envolvidos e pela grande variedade de padrões observados (diferentes distâncias e orientações). Apesar destas dificuldades os resultados obtidos fornecem importantes informações sobre a amplitude dos movimentos ocorridos durante a formação do depósito do Locus 3.

O movimento de peças por distâncias pequenas limitou-se, na maioria dos casos, às fácies em que os espécimes se encontravam. Nestes casos, existe grande probabilidade de que ambas as peças complementares tenham sido pouco deslocadas em relação à posição original. Sob esta perspectiva, tais ocorrências devem refletir episódios em que tanto a fragmentação, quanto a dispersão foram causadas simultaneamente pelo mesmo fator (e.g. pisoteio) 
e num mesmo evento.

Quando se trata de movimentos que extrapolam os limites das fácies, predominam as ocorrências com distâncias médias e grandes entre peças complementares. Para estes contextos não se exclui a possibilidade de que o mesmo fator fragmentou e dispersou, simultaneamente, um dos espécimes por considerável distância. Entretanto, a probabilidade de que a fragmentação e a considerável dispersão de um dos espécimes resultam de eventos distintos é grande (e.g. fragmentação por pisoteio e dispersão por escoamento superficial de água). Isto, por que um fator tafonômico que age sobre um elemento esquelético já fragmentado em vários espécimes pode afetar de maneira particular cada um deles (Roksandic, 2002), dispersando mais uns do que outros. É importante mencionar que no exemplo citado a dispersão também poderia ser causada pelo mesmo processo da fragmentação, que no caso é o pisoteio. Desde que isso não tenha ocorrido simultaneamente, a probabilidade de um evento secundário de pisoteio influenciar diferencialmente cada um dos espécimes é maior.

A ação desta sucessão de eventos sobre as peças complementares parece mais facilmente observável nos casos em que mais de dois espécimes formam o mesmo elemento esquelético. Estes casos dividem-se principalmente em dois grupos: 1) todas as peças ocorrem a distâncias pequenas umas das outras (até $20,0 \mathrm{~cm}$ ); e 2) duas das peças ocorrem a uma distância pequena em relação à outra (até $20,0 \mathrm{~cm}$ ) e uma terceira peça ocorre a uma distância média ou grande em relação às duas primeiras (de 20,1 até mais de 60,0 cm).

Segundo o raciocínio que vem sendo desenvolvido nesta seção, para os espécimes no primeiro grupo a fragmentação e a dispersão provavelmente 
ocorreram simultaneamente causadas pelo mesmo fator. Já para aqueles do segundo grupo, a fragmentação e a dispersão dos espécimes provavelmente representam eventos distintos. A fragmentação decorrendo de um evento primário, e a dispersão resultando de eventos posteriores, que influenciaram diferentemente cada um dos espécimes que formavam o mesmo elemento esquelético. Portanto, nos casos que se enquadram no segundo grupo, a fragmentação e a dispersão decorrem de ao menos dois eventos, mas provavelmente este número foi ainda maior.

A distribuição de peças complementares para as quais se verificou movimentos sub-horizontais representa o tipo mais comum de dispersão registrada no Locus 3. Tal distribuição das peças complementares sugere que, anteriormente à movimentação, os espécimes se encontravam numa mesma profundidade, ainda representando um mesmo elemento ósseo, ou em profundidades relativamente próximas, apresentando-se fragmentados por eventos prévios. Seja qual for o caso, o fato de que os movimentos foram predominantemente horizontais indica que a maior parte dos eventos de dispersão provavelmente ocorreu quando os espécimes transportados se encontravam expostos em superfície. Cabe ressaltar que como mais de um processo (e.g. queda de animais, pisoteio e escoamento superficial de água) poderiam resultar na distribuição espacial observada, não é possível identificar qual é(são) o(s) processo(s) responsável(is), o que representa um problema de equifinalidade.

Entre as peças complementares dispersas sub-horizontalmente, verificou-se que dois casos nos quais uma das peças se encontrava na fácies 4 e a outra na fácies 5 (Figura 3.15; vista de perfil, entre -150 e -160 de 
profundidade), podem lançar alguma luz sobre uma questão discutida por Haddad-Martim (2007). Segundo este autor, existe uma marcada diferença entre estas fácies, sendo que a 4 apresenta sedimentos inconsolidados e a 5 sedimentos cimentados (Haddad-Martim, 2007). Como argumentado por Haddad-Martim (2007), esta diferença, isoladamente, sugere a classificação destes sedimentos em duas fácies distintas. No entanto, o autor apresenta algumas evidências contrárias a esta separação. Uma delas é que alguns ossos apresentavam uma parte inserida nos sedimentos inconsolidados (fácies 4) e outra nos cimentados (fácies 5), sugerindo que, originalmente, estes ossos ocorriam num único sedimento cimentado que teve, posteriormente, a parte correspondente à área das bacias dissolvida (Haddad-Martim, 2007). A outra evidência é que não foram encontradas mudanças abruptas no arcabouço destes sedimentos e nem em suas colorações (Haddad-Martim, 2007). Desta forma, os dois casos de complementaridade entre peças dispersas subhorizontalmente e com um éspécime exumado da fácies 4 , e outro da facies 5 representam mais uma evidência contrária à separação destas fácies. Isto por que, a fragmentação e a dispersão sub-horizontal destes espécimes provavelmente ocorreram na superfície do mesmo sedimento, em tempos anteriores à dissolução na área das bacias.

Diferentemente dos movimentos sub-horizontais, aqueles que ocorreram verticalmente entre peças complementares tem menor amplitude. Apesar disso, os movimentos verticais chamam a atenção para a complexidade envolvida na formação deste depósito fossilífero do Locus 3. Isto por que, como visto, existe uma série de evidências de que os animais caíram no abismo e lá pereceram, tendo seus esqueletos sido desarticulados, fragmentados e dispersos in situ. 
Desta forma, o considerável deslocamento vertical de peças que integravam um mesmo elemento esquelético é bastante intrigante.

Outra diferença dos movimentos verticais em relação aos horizontais (e também outro exemplo da complexidade da formação do depósito) é que no primeiro caso, antes da fragmentação e da dispersão, um espécime poderia estar depositado na superfície ou soterrado. Assim, a queda e/ou o pisoteio por parte de outros animais, incluindo a megafauna, poderiam tanto fragmentar um espécime em superfície quanto dispersá-lo verticalmente por distâncias consideráveis. No caso de ossos soterrados os espécimes podem ter sido fragmentados e transportados durante movimentações de sedimentos e/ou através dos vazios que se formaram a partir disso, os quais foram registrados por Haddad-Martim, (2007) para o Locus 3. Por fim, como tem sido enfatizado, a complexidade envolvida na formação do pacote fossilífero do Locus 3 é grande e frequentemente a identificação dos processos tafonômicos envolvidos representa um problema de equifinalidade. 


\section{CONSIDERAÇÕES FINAIS E CONCLUSÃO}

Com relação ao Capítulo 2-Cura e identificação do material conclui-se que foram identificados 16 indivíduos de Tayassuidae, 9 de Cuniculus paca, 8 de Cervidae, 7 de Cuniculus major e 1 de Panthera onca. Os aspectos ecológicos dos grupos identificados que podem ter motivado a entrada dos animais na caverna são variados e atualmente não é possível avaliar qual deles foi preponderante.

A proporção entre o número mínimo de indivíduos de animais com diferentes pesos corporais e que fazem parte de níveis tróficos distintos é condizente com os padrões esperados segundo as comunidades naturais atuais.

Considerando que os grupos identificados aqui, em Mayer (2007) e em Hubbe (2008) representam uma variedade taxonômica pequena, e que ao mesmo tempo, estes animais apresentam pesos corporais muito distintos, o potencial de aprisionamento de animais do Locus 3 pode ser considerado complexo. A restrição espacial dos restos de megafauna à parte superior do depósito e a exposição gradativa das entradas da caverna (segundo o modelo de evolução sedimentar da Gruta Cuvieri; Haddad-Martim, 2007) constituem fortes evidências de que o potencial de aprisionamento de animais do Locus 3 se tornou mais abrangente ao longo da formação do pacote fossilífero.

Como visto no Capítulo 3-Tafonomia a formação do depósito fossilífero do Locus 3 é bastante complexa. Estão envolvidos vários processos bioestratinômicos e diagenéticos e a ação deles em muitos casos é simultânea e sobreposta. O problema da equifinalidade está presente em vários dos itens 
discutidos e a principal implicação disso é a impossibilidade de identificar mais detalhadamente a participação de alguns fatores em determinados processos.

A esporadicidade com que os animais caíram no abismo e a ocorrência de seus restos em diferentes fácies sedimentares, as quais, segundo os resultados obtidos aqui e em Hubbe (2008), depositaram-se lentamente, levam à conclusão de que o aprisionamento de animais no Locus 3 ocorreu durante um período considerável de tempo.

Os processos de necrólise, desarticulação, dispersão e fragmentação ocorreram mais ou menos simultaneamente e em intensidades variáveis. Desta forma, a natureza confinada do Locus 3 , a grande densidade de fósseis e a sedimentação lenta contribuíram para que os processos mencionados favorecessem a mistura horizontal e vertical de ossos de diferentes indivíduos e táxons.

Apesar dos problemas relacionados à fragmentação, conclui-se que este foi um processo muito importante que atuou desde a necrólise das carcaças até após o soterramento final dos fósseis. O percentual de peças fragmentadas observado aqui é bastante alto e muito semelhante ao verificado por Hubbe (2008) para os megamamíferos por ele analisados. O pisoteio foi identificado como o principal agente de fragmentação do material, o que também foi constatado por Hubbe (2008) para os restos de megafauna. Com base na abrangência espacial e temporal dos demais fatores de fragmentação concluise que a queda de animais e de blocos teve um papel secundário e que a influência da compactação da coluna sedimentar foi ainda mais subordinada. De maneira geral, os fatores de fragmentação caracterizam-se principalmente por atingirem diferentes espécimes independentemente, apesar da associação 
espacial entre eles. Chamo a atenção também para o fato de que em alguns casos as brechas fossilíferas do Locus 3 contribuíram contrariamente à fragmentação do material, preservando parte dos restos de um taiassuideo identificado aqui e de alguns ossos da megafauna analisados por Hubbe (2008).

Depois da fragmentação, o intemperismo climático foi o fator que mais modificou a superfície dos restos ósseos analisados. Apesar das diferenças entre as propriedades físicas de ossos de meso e de megamamíferos as intempéries agiram sobre um percentual de peças muito semelhante nestes dois grupos de animais. Além disso, tanto a distribuição espacial das peças intemperizadas analisadas aqui, quanto em Hubbe (2008), permitem concluir que a sedimentação no Locus 3 foi lenta. A ação do intemperismo sobre os ossos depositados no Locus 3 ocorreu principalmente enquanto estes estavam em superfície, mas uma parte destes espécimes também sofreu a ação do intemperismo após ser re-exposta à interface ar/sedimento.

Abrangendo uma parcela menor do que a alterada pelo intemperismo, a abrasão teve uma contribuição modesta na formação do depósito estudado. Esta conclusão é válida para o pacote fossilífero como um todo, pois os resultados obtidos aqui e em Hubbe (2008) são afins. Embora a abrasão tenha ocorrido principalmente em superfície e em decorrência da ação da água, com base nos dados dos meso e megamamíferos conclui-se que a dinâmica hidrológica no interior do Locus 3 se caracterizava por gotejamentos, escoamentos superficiais e poças, em oposição a fluxos correntes e contínuos. O regime hídrico teve ainda um papel importante no retrabalhamento do material do Locus 3, envolvendo tanto a abrasão em superfície, quanto a re- 
exposição de peças previamente soterradas.

A identificação dos carnívoros e roedores responsáveis pelas marcas observadas no material carece de maiores esclarecimentos, mas com base nos dados disponíveis a contribuição destes animais para a formação do pacote fossilífero pode ser considerada diminuta.

A distribuição espacial das peças complementares permite concluir que naquelas fortemente associadas espacialmente a fragmentação e a dispersão provavelmente agiram simultaneamente, mais provavelmente causadas pelo mesmo fator. Já naquelas muito distanciadas a fragmentação e a dispersão representam, mais provavelmente, eventos distintos que influenciaram diferentemente cada um dos espécimes que formavam o mesmo elemento esquelético. Nestes casos, os fatores de fragmentação e dispersão não foram necessariamente os mesmos.

Com relação aos movimentos sub-horizontais de peças complementares conclui-se que tais episódios ocorreram em superfície ao longo de diferentes momentos da formação do pacote fossilífero. Conclui-se também que a complementaridade entre peças das fácies 4 e 5 fortalecem o argumento de Haddad-Martim (2007) de que ambas as fácies representam um mesmo depósito sedimentar que foi parcialmente alterado (por cimentação e dissolução) após a deposição.

Em alguns casos a dispersão vertical entre peças complementares atingiu profundidades consideráveis. Mediante as diversas evidências de que os animais caíram e pereceram no Locus 3 e seus esqueletos foram fragmentados e dispersos in situ conclui-se que as movimentações de sedimentos e a formação de vazios foram importantes na dispersão vertical de 
peças complementares por grandes distâncias.

De maneira geral, as conclusões aqui apresentadas têm importantes implicações para o estudo de mamíferos pleistocênicos, pois grande parte do conhecimento disponível sobre estes animais foi obtida a partir de depósitos em cavernas, tanto no Brasil (Auler et al,. 2006), quanto no exterior (por exemplo, Brown and Wells, 2000; Kos, 2003a, 2003b; Ostbye et al., 2006; Simms, 1994; Wang and Martin, 1993 e White et al., 1984). Mais especificamente, as conclusões apresentadas são importantes no que se refere à associação espacial entre restos fósseis de depósitos cavernícolas. Isto por que, como demonstrado, a formação destes testemunhos da vida pretérita está sujeita a uma ampla gama de processos complexos, tanto de natureza geológica, quanto biológica. Desta forma, a ocorrência de restos de diferentes animais em um mesmo depósito fossilífero ou em um mesmo nível estratigráfico não necessariamente atesta a contemporaneidade destes animais. Sendo assim, a identificação taxonômica dos restos presentes em um depósito fossilífero, por si própria, apresenta um potencial muito limitado (e potencialmente enviesado) para subsidiar interpretações deposicionais e paleoambientais. Portanto, a busca por tais informações deve ter como prérequisito a realização de estudos detalhados sobre aspectos estratigráficos, cronológicos e tafonômicos do depósito fossilífero em questão. 


\section{REFERÊNCIAS}

Alberdi, M.T., Cartelle, C. \& Prado, J.L. 2003. El registro de Equus (Amerhippus) e Hippidion (Mammalia, Perissiodactyla) de Brasil. Consideraciones paleoecológicas e biogeográficas. Ameghiniana (Ver. Asoc. Paleontol. Argent.) 40(2): 173-196.

Alcover, J.A., Sans, A, Palmer, M., 1998. The Extent of Extinctions of Mammals on Islands. Journal of Biogeography, 25 : 913-918.

Andrews, B.N., 2006. Sediment consolidation and archaeological site formation. Geoarchaeology: an international journal. 21:461-478.

Auler, A.S.; Piló, L.B.; Smart, P.; Wang, X.; Neves, W.A.; Cheng, H. e Edwards, L.E., 2003. Cronologia e processos de deposição da megafauna quaternária em cavernas brasileiras. Congresso da Associação Brasileira de Estudos do Quaternário - ABEQUA, 9.2003. Resumos, Recife, 1 CD (212 PDF), 3.

Auler, A.S.; Piló,L.B.; Smart,P.L.; Wang,X.; $\quad$ Hoffmann,D.; Richards,D.A.; Edwards,R.L.;. Neves,W.A. Cheng, H., 2006. U-series dating and taphonomy of Quaternary vertebrates from Brazilian caves. Paleogeography, Paleoclimatology, Paleoecology, 240: 508-522.

Auler, A.S., Smart, P.L., Wang, X., Piló, L.B., Edwards, R.L., Cheng, H., 2009. Cyclic sedimentation in Brazilian caves: Mechanisms and palaeoenvironmental significance. Geomorphology, 106: 142-153.

Barlow, C., 2000. The ghosts of evolution - nonsensical fruit, missing partners, and other ecological anachronisms. Basic Books, New York. 
Badgley, C. 1986a. Counting individuals in mammalian fossil assemblages from fluvial environments. Palaios, 1: 328-338.

Badgley, C. 1986b. Taphonomy of mammalian fossil remains from Siwalik Rocks of Pakistan. Paleobiology. 12: 119-142.

Begon, M., Towsend, C.R. e Harper, J. 2007. Ecology: from individuals to ecosystems. Blackwell publishing, Malden.

Behrensmeyer, A. K. 1978. Taphonomic and ecologic information from Bone Weathering. Paleobiology, 4: 150-162.

Behrensmeyer, A. K. 1984. Taphonomy and the fossil record. American Scientist, 72: 558-556.

Behrensmeyer, A. K. e S.M. Kidwell, 1985. Taphonomy's contributions to paleobiology. Paleobiology, 11: 105-119.

Behrensmeyer, A. K., S.M. Kidwell e Gastaldo R.A., 2000. Taphonomy and paleobiology. Paleobiology, 26: 103-147.

Behrensmeyer, A. K., J. D. Damuth, W. A. DiMichele, R. Potts, H.D. Sues e S. L. Wing. 1992. Terrestrial ecosystems through time: evolutionary paleoecology of terrestrial plants and animals. The University of Chicago Press, Chicago.

Binford.,L.R.,1981. Bones: ancient man and modern miths. Academic press, New York.

Brightsmith, D., 2002. Disponível em http://ebookbrowse.com/claylick-seasonality-afa-pdf-d40396908. 
Brown, S.P. e Wells, R.T., 2000. A Middle Pleistocene vertebrate fossil assemblage from Cathedral Cave, Naracoorte, South Australia. Transactions of Royal Society of South Australia,124: 91-104.

Cartelle, C. 1980. Estudo comparativo de rádio e esqueleto da mão de Glossotherium (Ocnotherium) giganteum Lund, 1842. Anais da Academia Brasileira de Ciências. 52(2): 359-377.

Cartelle, C. 1991. Um novo Mylodontinae (Edentata, Xenarthra) do Pleistoceno Final da região Intertropical Brasileira. Anais da Academia Brasileira de Ciências

Cartelle, C., 1994a. Tempo passado. Mamíferos fósseis em Minas Gerais. EditoraPalco, Belo Horizonte.

Cartelle, C. 1994b. Presença de Lama (Artiodactyla, Camelidae) no Pleistoceno Final - Holoceno da Bahia. Acta Geológica Leopoldensia.17: 399-410.

Cartelle, C. 1994c. Anomalias e desenvolvimento dentário em algumas espécies extintas de mamíferos do Brasil intertropical. Acta Geológica Leopoldensia. 17: 573-584.

Cartelle, C. 1998. Um pequeno urso do Pleistoceno Final da Bahia. Acta Geológica Leopoldensia. (46/47): 171-189.

Cartelle, C.,1999. Pleistocene mamals of the Cerrado and Caatinga of Brazil. In Eisenberg, J.F., e Redford, K.H. Mammals of the neotropics, the central neotropics, Ecuador, Peru, Bolivia Brazil. University of Chicago Press, Chicago. 
Cartelle, C. \& Ferreira, M.A.C. 1994. Nota prévia sobre primatas pleistocênicos brasileiros. Acta Geológica Leopoldensia. 17: 411-414.

Cartelle, C. \& Iuliis, G.1995. Eremotherium laurillardi: the panamerican late pleistocene Megatherid sloth. Journal of Vertebrate Paleontology. 15(4): 830-841.

Cartelle, C. \& Lessa, G. 1988. Descrição de um novo gênero e espécie de Macraucheniidae (Mammalia, Litopterna) do Pleistoceno do Brasil. Paulacoutiana, 3:3-26.

Cartelle, C. \& Mahecha, G.A.B. 1985. Pampatherium paulacoutoi uma nova espécie de tatu gigante da Bahia, Brasil (Ledentata, Dasypodidae). Revista Brasileira de Zoologia. 2(4): 229-254.

Cartelle, C., 2002. Peter W. Lund, a naturalist of several sciences. Lundiana, 3: 83-85.

Cartelle, C., luliis, G., Ferreira, R. L., 2009. Systematic revision of tropical Brazilian Scelidotheriine sloths (Xenarthra, Mylodontoidea). Journal of Vertebrate Paleontology 29: 555-566.

Cheverud, J.M. Relationships among ontogenetic, static, and evolutionary allometry. American Journal of Physical Anthropology. 59:139149.

Clark, P.U. e Mix, A.C., 2002. Ice sheets and sea level of the Last Glacial Maximum. Quaternary Science Reviews 21: 1-7.

Cohen, J.E., Jonsson, T. e Carpenter, S.R., 2003. Ecological community description using the food web, species abundance, and body size. PNAS, 100: 1781-1786. 
Cunha, F.L.S., Andrade, A.B., Zucon, M.H. e Santos, M.M., 1985. Ocorrência de mamífero fóssil pleistocênico localizado em Monte Alegre, Sergipe, Brasil. Coletâneas de Trabalhos Paleontológicos (DNPM), 7(2):29-33 .

Czaplewski, N.J. \& Cartelle, C.1998. Pleistocene bats deposits in Bahia, Brazil. Journal of mammalogy. 79(3): 784-803.

Czaplewskii, N. J., Puckette, W.L. e Russel, C., 2002. A pleistocene tapir and associated mammals from the southwestern Ozakh Highland. Journal of cave and Karst studies.

Damuth, J., 1981. Population density and body size in mammals. Nature, 290: 699-700.

Driesch, A.V.D., 1976. A guide to measurement of animal bones from archaeological sites. Peabody Museum Bulletin 1. Harvard University, Cambridge.

Efremov, I.A., 1940. Taphonomy: a new branch of paleontology. Pan American Geologist 74(2): 81-93.

Eisenberg, J.F., e Redford, K.H. 1999. Mammals of the neotropics, the central neotropics, Ecuador, Peru, Bolivia Brazil. University of Chicago Press, Chicago.

Fernández-Jalvo,Y., 2002. Morphological taphonomic transformations of fossil bones in continental enviromnents, and repercussions on their chemical composition. Archaeometry, 44: 353-361.

Ford, D. e Williams, P., 1994. Karst Geomorphology and Hidrology. Chapman and Hall, Londres. 
Gasse, F., 2000. Hydrological changes in the African tropics since the Last Glacial Maximum. Quaternary Science Reviews, 19:189-211.

Gilinsky, L. N. \& Bennington, J.B. 1994. Estimating numbers of whole individuals from collections of body parts: a taphonomic limitation of the paleontological record. Paleobiology. 20: 245-258.

Gillieson, D. 1996. Caves - Processes, Development, Management., Blackwell, Oxford.

Goes, F.A.S., Vieira, F.S., Zucon M.H., Cartelle, C. \& Teodósio, C. 2002. Ocorrência de mamíferos pleistocênicos em Sergipe, Brasil. Arquivos do Museu Nacional, Rio de Janeiro. 60: 199- 206.

Grayson, D.K. 1984. Quantitative zooarchaeology: topics in the analisys of archaeological faunas. Academic Press, Orlando.

Guérin, C., 1991. La faune de vertébrés du Pléistocène supérieur de l'aire archéologique de São Raimundo Nonato (Piaui, Brésil). Comptes Rendus de l'Académie des Sciences des Paris. 312: 567-572.

Guthrie, R.D., 1984. In Quaternary extinctions - a prehistoric revolution. The University of Arizona Press. Tucson.

Guthrie, R.D., 2003. Rapid body size decline in Alaskan Pleistocene horses before extinction. Nature, 426: 169-171.

Haddad-Martim, P.M., 2007. Caracterização dos depósitos clásticos fossilíferos da Gruta Cuvieri, Matozinhos-MG. Monografia de Trabalho de Formatura. Instituto de Geociências-Universidade de São Paulo. 
Hadler, P., Ferigolo, J., Goin, F.J., 2009. Mamíferos de pequeno porte (Didelphimorphia, Chiroptera e Rodentia) do Pleistoceno final/Holoceno do Brasil, com ênfase no Rio Grande do Sul. In: Ribeiro, A. M.; Bauermann, S.; Scherer, C. (Orgs.). Quaternário do Rio Grande do Sul: integrando conhecimentos. 1 ed. Porto Alegre. pp. 155-170.

Haglund, W.D.,1996. In Haglund W. D. e Sorg M. H. Forensic taphonomy - the postmortem fate of human remains. CRC Press, Florida.

Haynes G., 1980. Evidence of carnivore gnawing on Pleistocene and recent mammalian bones. Palaeobiology 6 (3): 341-351.

Haynes, G., 1983. A guide for differentiating mammalian carnivore taxa responsible for gnaw damage to herbivore limb bones. Paleobiology, 9: $164-172$.

Hofman, J.L., 1992. Putting the pieces together: an introduction to refitting. In Hofman e J.L. e Enloe, J.G., In Piecing together the past : applications of refitting studies in archaeology. Tempus Reparatum, Oxford.

Hill, A., 1979. Disarticulation and scattering of mammal skeletons. Paleobiology, 5: 261-274.

Hershkovitz, P.,1956. Nature mystery: the secret of the paca's pouches. Chicago Natural History Museum Bulletin. 7:5-7.

Holz, M. \& Simões, M. G. 2002. Elementos fundamentais de Tafonomia. Editora da Universidade - UFRS, Porto Alegre.

Hubbe, A., 2008. Contextualização taxonômica, tafonômica e morfométrica dos remanescentes ósseos da megamastofauna da Gruta 
Cuvieri (MG), um sítio paleontológico do Pleistoceno tardio. Dissertação de Mestrado. Instituto de Biociências - Universidade de São Paulo.

Iuliis, G. \& Cartelle, C. 1993. The medial carpal and metacarpal elements of Eremotherium and Megatherium ( Xenarthra: Mammalia). Journal of Vertebrate Paleontology.13(4): 525-533.

luliis, G. \& Cartelle, C. 1999. A new giant megatheriine ground sloth (Mammalia: Xenarthra: Megatheriidae) from the late Blancan to early Irvingtonian of Florida. Zoological Journal of the Linnean Society. 127: 495-515.

Jonhson, C.N., 2002. Determinants of loss of mammal species during the Late Quaternary 'megafauna' extinctions: life history and ecology, but not body size. Proceedings of the Royal Society of London. 269: 22212227.

Kidwell, S.M., 1985. Paleobiological e sedimentological implications of fossil concentrations. Nature, 318: 457-460.

Kidwell, S.M., 1986. Models for Fossil Concentrations: Paleobiologic Implications. Paleobiology, 12: 6-24.

King,J.E. e Saunders, J.J., 1984. Environmental insularity and the extinction of the American mastodont. In: Quaternary extinctions - a prehistoric revolution. The University of Arizona Press. Tucson.

Kingdon, J., 1988. East African Mammals: an atlas of evolution in Africa, Volume 2, Part B: Hares and Rodents. University of Chicago Press, Chicago

Kipnis, R., 1998. Early hunter-gatherers in the Americas: perspectives 
from central Brazil. Antiquity, 72:581-592.

Klein, R. G. \& Cruz-Uribe, K. 1984. The analysis of animal bones from archeological sites - Prehistoric Archaeology and Ecology. University of Chicago Press, Chicago.

Kos, A.M. 2003a. Characterisation of post-depositional taphonomic processes in the accumulation of mammals in a pitfall cave deposit from southeastern Australia. Journal of Archaeological Science, 30: 781-796.

Kos, A.M. 2003b. Pre-burial taphonomic characterisation of a vertebrate assemblage from a pitfall cave fossil deposit in southeastern Australia. Journal of Archaeological Science,30: 769-779.

Larson, M.L. e Ingbar E.E., 1992. Perspectives on refitting: critique and a complementary approach. In Hofman e J.L. e Enloe, J.G., Piecing together the past : applications of refitting studies in archaeology. Tempus Reparatum, Oxford.

Lobo, H.A.S., Perinotto, A.J.A., Poudou, S., 2009. Análise de agrupamentos aplicada à variabilidade térmica da atmosfera subterrânea: contribuição ao zoneamento ambiental microclimático de caverna. Revista de Estudos Ambientais, 11: 22-35.

Lund, P.W., 1950. Memórias sobre a paleontologia brasileira - revistas e comentadas por Carlos de Paula Couto. Instituto Nacional do Livro, Rio de Janeiro.

Lyman, R.L. 1994a. Vertebrate taphonomy - Cambridge Manuals in Archaeology. Cambridge University Press, Cambridge.

Lyman, R.L. 1994b. Relative abundances of skeletal specimens and 
taphonomic analysis of vertebrate remains. Palaios, 9: 288-298.

Lyman, R.L. 2010. What taphonomy is, what it isn't, and why taphonomists should care about the difference. Journal of Taphonomy, 8:1-16.

Magalhães, R.M.M., Mello, M.G.S. \& Bergqvist, L.P. 1992. Os cérvidas pleistocênicos da região nordeste brasileira. Anais da Academia Brasileira de Ciências. 64(2): 149-154.

Mares, M.A. e Lacher Jr., T.E., 1987. Ecological, morphological, and behavioral convergence in rock-dwelling mammals in Current Mammalogy, edited by Genoways, H.H. Plenum Publishing Corporation, New York.

Margarido e Mangini, 2001. In Fowler M.E. e Cubas Z.S., Biology, medicine, and surgery of South American wild animals. Iowa State University Press, lowa.

Martin, R.A. e Barnosky, A.D.,1993. Morphological change in quaternary mammals of North America. Cambridge University Press, Cambridge.

Mayer, E.L. 2007. Caracterização dos mamíferos de pequeno e médio porte da transição Pleistoceno/Holoceno da Gruta Cuvieri, Lagoa Santa, Minas Gerais. Monografia de Conclusão de Curso. Faculdade de Filosofia, Ciências e Letras-Centro Universitário Fundação Santo André, Santo André.

Miller, W.C., 2007. In Charles W.C. Trace fossils: concepts, problems, prospects. Elsevier, Oxford.

Moojen, J., 1952. Os Roedores do Brasil. Rio de Janeiro: Instituto 
Nacional do Livro, Biblioteca Científica Brasileira, 214pp.

Moreno-Valdez, A., P.A. Lavín-Murcio y O.M. Hinojosa-Falcón. 1997. El Tepezcuintle Agouti paca (Rodentia: Agoutidae), en Tamaulipas. Revista Mexicana de Mastozoología. 2:129-131.

Neves, W.A. 1988. Uma proposta pragmática para a cura e recuperação de coleções de esqueletos humanos de origem arqueológica. Boletim do Museu Paraense Emílio Goeldi. Série Antropológica, 4: 3-27.

Neves, W.A. \& Piló, L.B. 2003 Solving Lund’s Dilemma: New AMS dates confirm that humans and megafauna coexisted at Lagoa Santa. Current Research in the Pleistocene, 20: 57-60.

Neves, W.A. \& Piló, L.B. 2008. O povo de Luzia. Editora Globo, São Paulo.

Nielsen-Marsh, C., Gernaey, A.,Turner-Walker, G., Hedges,R., Pike, A. e Collins, M., 2000. The chemical degradation of bone. In Cox, M. e Says, S. Human Osteology: in archaeology and forensic science.

Nowak, R.M., 1999. Walker's mammals of the world. Sixth edition. The Johns Hopkins University Press, Baltimore.

Nunes, A.L.V., Mangini, P.R., Ferreira J.R.V., 2001. In Fowler M.E. e Cubas Z.S., Biology, medicine, and surgery of South American wild animals. lowa State University Press, lowa.

Oliveira, F.S., Canola, J.C., Machado, M.R.F. e Camargo, M.H.B., 
2006. Descrição anátomo-radiográfica do esqueleto axial da paca (Agouti paca, Linnaeus, 1766). Acta Scientiae Veterinariae. 34(3): 331-334.

Ostbye, E., Lauritzen, S., Moe, D. e Ostbye, K., 2006. Vertebrate remains in Holocene cave sediments: faunal sucession in the Sirijorda Cave, northern Norway. Boreas, 35: 142-158.

Pachaly, J.R., Acco, A., Lange. R.R., Nogueira, T.M.R., Nogueira, M.F. e Ciffoni, E.M.G., 2001. In Fowler M.E. e Cubas Z.S. Biology, medicine, and surgery of South American wild animals. lowa State University Press, lowa.

Patterson, B. and Pascual, R. 1968. The fossil mammal fauna of South America. Quarterly Review of Biology, 43:409-451

Paula Couto, C.1953. Paleontologia brasileira: Mamíferos. Ministério da Educação e Saúde, Instituto Nacional do Livro, Rio de Janeiro.

Paula Couto, C. 1970. Paleontologia da região de Lagoa Santa, Minas Gerais, Brasil. Boletim do Museu de História Natural U.F.M.G.- Geologia, 1: 1-21.

Paula Couto, C. 1971. Mamíferos fósseis das cavernas de Minas Gerais. Espeleologia ano III (3-4): 3-14.

Paula Couto, C. 1975. Mamíferos fósseis do Quaternário do sudeste brasileiro. Boletim Paranaense de Geociências. 33: 89-132.

Paula Couto, C. 1977. On a large Megalonychidae ground sloth from the Pleistocene of Rio Grande do Sul. Anais da Academia Brasileira de Ciências. 49(2): 297-299. 
Paula Couto, C. 1979. Tratado de paleomastozoologia. Academia Brasileira de Ciências, Rio de Janeiro.

Paula Couto, C. 1980. Fóssil pleistocene to sub-recent mammals from northeastern Brazil. I- Edentata Megalonychidae. Anais da Academia Brasileira de Ciências. 52(1): 143-151.

Pérez, E. M. 1992. Agouti paca. Mammalian Species. 404: 1-7.

Pictet, F.J, 1844. Traité élémentaire de paléontologie ou Histoire naturelle des animaux fossiles - Consideres dans leurs rapports zoologiques et geologiques. Langlois et Leclerq, Paris.

Piló, L.B. e Neves, W.A. 2003. Novas datações 14C(AMS) confirmam a tese da coexistência do homem com a megamastofauna pleistocênica na região de Lagoa Santa, MG. Congresso da Associação Brasileira de Estudos do Quaternário - ABEQUA, 9. 2003. Resumos, Recife, 1 CD (212 PDF), 4.

Rios-Uzeda, B. Wallace, R.B. e Vargas, J. 2004. La Jayupa de la altura (Cunicilus taczanowskii, Rodentia, Cuniculidae), um nuevo registro de mamífero para la fauna de Bolívia. Mastozoologia Neotropical. 11:109114.

Rusconi, C. 1932. Apuntes sobre algunos restos de mamíferos fosiles procedentes del Brasil. Boletines de la Sociedad Geológica del Perú. 5:23-26.

Reed, E.H., 2006. In situ taphonomic investigation of Pleistocene large mammal boné deposits from the Ossuaries, Victoria fóssil cave, Naracoorte, South Australia. Helictite, 39: 5-15. 
Roksandic, M., 2002. In Haglung, W. D., Sorg M.H. Advances in forensic taphonomy,pp. 95-113.

Santana, J.J., Albuquerque, J.F.G., Moura, C.E.B., Costa, W.P., Oliveira, M.F., Barreto Júnior, R.A. e Miglino, M.A., 2003. Origem do plexo braquial de mocós (Kerodon rupestris wied, 1820). Brazilian Journal of Veterinary Research and Animal Science, 40: 391-396.

Simms, M.J.1994. Emplacement and preservation of vertebrates in caves and fissures. Zoological Journal of the Linnean Society, 112: 261283.

Shipman, P., 1981. Life history of a fossil: An introduction to taphonomy and paleoecology. Harvard University Press, Cambridge.

Tanzilo, T., 2007. Reading X Y coordinates from Excel or similar. Disponível em: www.icon-optics.com/library/pointlsp.pdf.

Todd, L.C., Frison, G.C., 1992. Reassembly of bison skeletons from the horner site: a study in anatomical refitting. In In Hofman e J.L. e Enloe, J.G., Piecing together the past: applications of refitting studies in archaeology. Tempus Reparatum, Oxford.

Todd, L.C., Standford, D.J., 1992. Application of conjoined bone data to site structural studies. In In Hofman e J.L. e Enloe, J.G., Piecing together the past: applications of refitting studies in archaeology. Tempus Reparatum, Oxford.

Toledo, P.M. 1998. Locomotory patterns within the Pleistocene sloths. Coleção Friedrich Katzer, Museu Goeldi, Belém.

Tuttle, M.D. e Stevenson, D.E., 1978. Variation in the cave 
environment and its biological implications. In Zuber, R., Chester, J. Gilbert, S. e Rhodes, D., 1977 National Cave Management Symposium Proceedings. Adobe Press, New Mexico, 108-121.

Villa, P., 1982. Conjoinable pieces and site formation processes. American Antiquity, 47:276-290.

Wang, X. e Martin, L., 1993. Natural trap cave. National Geographic Research \& Exploration, 9:422-435.

Wemmer, C. 1998. Deer: Status Survey and Conservation Action Plan. IUCN, Cambridge.

White, J.A., McDonald, H.G., Anderson E. e Soiset, J.E., 1984. Lava blisters as carnivoran traps. Special publication Carnegie Museum of Natural History, 8: 241-255.

Wilson, D. E., and D. M. Reeder (eds). 2005. Mammal species of the world: a taxonomic and geographic reference (third edition). Johns Hopkins University Press, Washington.

Winge, H. 1888. (1887). Jordfundne og Nulevende gnavere. (Rodentia) fra Lagôa Santa, Minas Geraes, Brasilien. E. Museo Lundii. 1:1-178. 


\section{ANEXO I}

Este anexo destina-se à descrição detalhada dos procedimentos adotados no processamento dos dados bidimensionais dos desenhos de campo a fim de representá-los tridimensionalmente.

Inicialmente, cada folha dos desenhos feitos em campo foi digitalizada utilizando-se um escâner A3 e o arquivo resultante foi salvo em formato jpeg.

Os arquivos jpeg de cada folha de uma mesma exposição foram abertos no programa Corel Photo Paint ${ }^{R}$ para remoção das áreas exteriores aos eixos de referência, que são as margens do papel. Como resultado, duas bordas de cada folha passaram a coincidir com o traçado dos eixos ali representados. Cada folha já sem margem foi novamente salva no formato jpeg.

O arquivo jpeg de cada folha sem margem foi importado no programa CorelDRAW ${ }^{R}$ e justaposto às demais folhas da mesma exposição, segundo os eixos e a origem. Esta composição foi, então, exportada no formato jpeg.

As composições foram abertas no programa tpsDig (disponível gratuitamente em: http://life.bio.sunysb.edu/morph/soft-dataacq.html). Primeiramente, utilizando-se a ferramenta landmark foram marcados dois pontos de referência cuja coordenada é conhecida nos desenhos de campo. Um dos pontos escolhidos foi a origem $(0,0)$ e outro a 100 centímetros a leste e a sul $(100,-100)$. Estes pontos de referência foram os primeiros a serem marcados em todas as composições das exposições. O programa registrou estes pontos e atribuiu a eles valores relativos de coordenadas em duas dimensões ( $\mathrm{X}$ e $\mathrm{Y})$.

$\mathrm{Na}$ seqüência, utilizando a mesma ferramenta, clicou-se sobre o desenho de cada resto fóssil de cada composição. Como o objetivo deste 
procedimento é representar cada osso/fragmento através de um ponto, as coordenadas foram tomadas no centro de cada fóssil. Este procedimento foi realizado seguindo a ordem crescente da numeração dos fósseis para facilitar a posterior correspondência entre as coordenadas relativas registradas pelo programa tpsDig e a numeração atribuída às peças durante a escavação, representada em uma planilha a parte.

Após registrar as coordenadas relativas de todas as peças de uma exposição estes dados foram salvos na aba Save > Save data com o formato tps.

As coordenadas relativas em formato tps foram importadas no Microsoft Excel $^{\mathrm{R}}$ pela aba Dados $>$ De Texto $>$ Arquivo Delimitado Por Espaço. Cada valor de $\mathrm{X}$ e $\mathrm{Y}$ é automaticamente posicionado em uma célula, o primeiro à esquerda do segundo.

Para converter as coordenadas relativas nas coordenadas reais registradas no Locus 3 aplicou-se duas equações álgebra linear utilizando os valores relativos de $X$ e $Y$ da origem $(0,0)$ e do outro ponto de referência definido previamente $(100,-100)$ :

$$
\begin{aligned}
& X_{L 3}=\left\{x_{\text {rel }} /\left[\left(x_{\text {ref }}-x_{0}\right) / 100\right]\right\}-\left\{x_{0} /\left[\left(x_{\text {ref }}-x_{0}\right) / 100\right]\right\} \\
& Y_{L 3}=\left\{y_{\text {rel }} /\left[\left(y_{\text {ref }}-y_{0}\right) / 100\right]\right\}-\left\{y_{0} /\left[\left(y_{\text {ref }}-y_{0}\right) / 100\right]\right\} .(-1)
\end{aligned}
$$

Sendo que na equação 1: $\mathrm{X}_{\mathrm{L} 3}$ - coordenada real do eixo $\mathrm{X}$ registrada para determinado espécime no Locus $3 ; \mathrm{x}_{\text {rel }}$ - coordenada relativa do eixo $\mathrm{X}$ registrada no programa tpsDig para cada espécime; $\mathrm{x}_{\text {ref }}$ - coordenada relativa de referência registrada no programa tpsDig para o ponto $100,-100$ de cada 
composição; $x_{0}$ - coordenada relativa de referência registrada no programa tpsDig para a origem (ponto 0,0) de cada composição.

Sendo que na equação 2: $Y_{\mathrm{L} 3}$ - coordenada real do eixo $Y$ registrada para determinado espécime no Locus $3 ; \mathrm{y}_{\text {rel }}$ - coordenada relativa do eixo $\mathrm{Y}$ registrada no programa tpsDig para cada espécime; $y_{\text {ref }}$ - coordenada relativa de referência registrada no programa tpsDig para o ponto $100,-100$ de cada

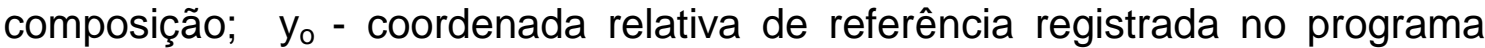
tpsDig para a origem (ponto 0,0 ) de cada composição.

A primeira equação converteu os dados do eixo $X$ (eixos leste e oeste) e a segunda os dados do eixo $\mathrm{Y}$ (eixos norte e sul).

Ao lado dos valores das coordenadas $\mathrm{X}$ e $\mathrm{Y}$ reais obtidas com as equações 1 e 2 inseriram-se manualmente os valores de profundidade (eixo Z) da área do Lócus mais próxima a aquela em que o fóssil se encontrava, segundo a exposição em questão. $\mathrm{O}$ arquivo com as coordenadas $\mathrm{X}, \mathrm{Y}$ e $\mathrm{Z}$ reais foi salvo em formato csv.

O arquivo csv foi aberto no programa Bloco de $\operatorname{Notas}^{\mathrm{R}}$ e com a função Localizar/Substituir trocou-se as vírgulas (,) por pontos (.) e posteriormente, os pontos e vírgulas (;) por vírgulas (,). Feito isso, alterou-se a extensão do arquivo de csv para scr. Estes procedimentos são fundamentais para a leitura correta das coordenadas pelo programa tridimensional utilizado.

Finalmente, deve se carregar o aplicativo Autolisp (disponível gratuitamente em: http://www.cadforum.cz) no programa tridimensional AutoCAD-3D ${ }^{R}$ (versão para estudante 2011; disponível gratuitamente em: http://students.autodesk.com/). Feito isso, o arquivo scr pode ser importado através do comando ascpoint. $I s p^{R}$, segundo o procedimento descrito por 
Tanzillo (2007). Esta etapa consiste basicamente em carregar o aplicativo no programa tridimensional, selecionar o arquivo de dados desejado (formato scr) e indicar um modelo sólido de referência a ser posicionado nos pontos determinados pelas coordenadas. Este modelo sólido de referência deve ser posicionado na origem (coordenada 0,0,0). Após a plotagem dos modelos sólidos, aquele que serviu de referência deve ser excluído da reconstituição virtual. 